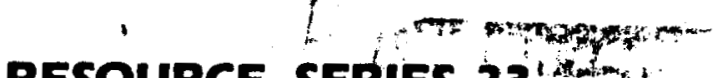
RESOURCE SERIES $23^{\text {inIm. }}$ DOEF/ET/28365-23

\title{
GEOTHERMAL RESOURCE ASSESSMENT
}

\section{OF HOT SULPHUR SPRINGS, COLORADO}

by

Richard Howard Pearl

DO NOT MICROFILM

Ted G. Zacharakis

Charles D. Ringrose

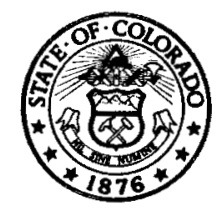

COLORADO GEOLOGICAL SURVEY

DEPT. OF NATURAL

RESOURCES

DENVER, COLORADO / 1982

COVER

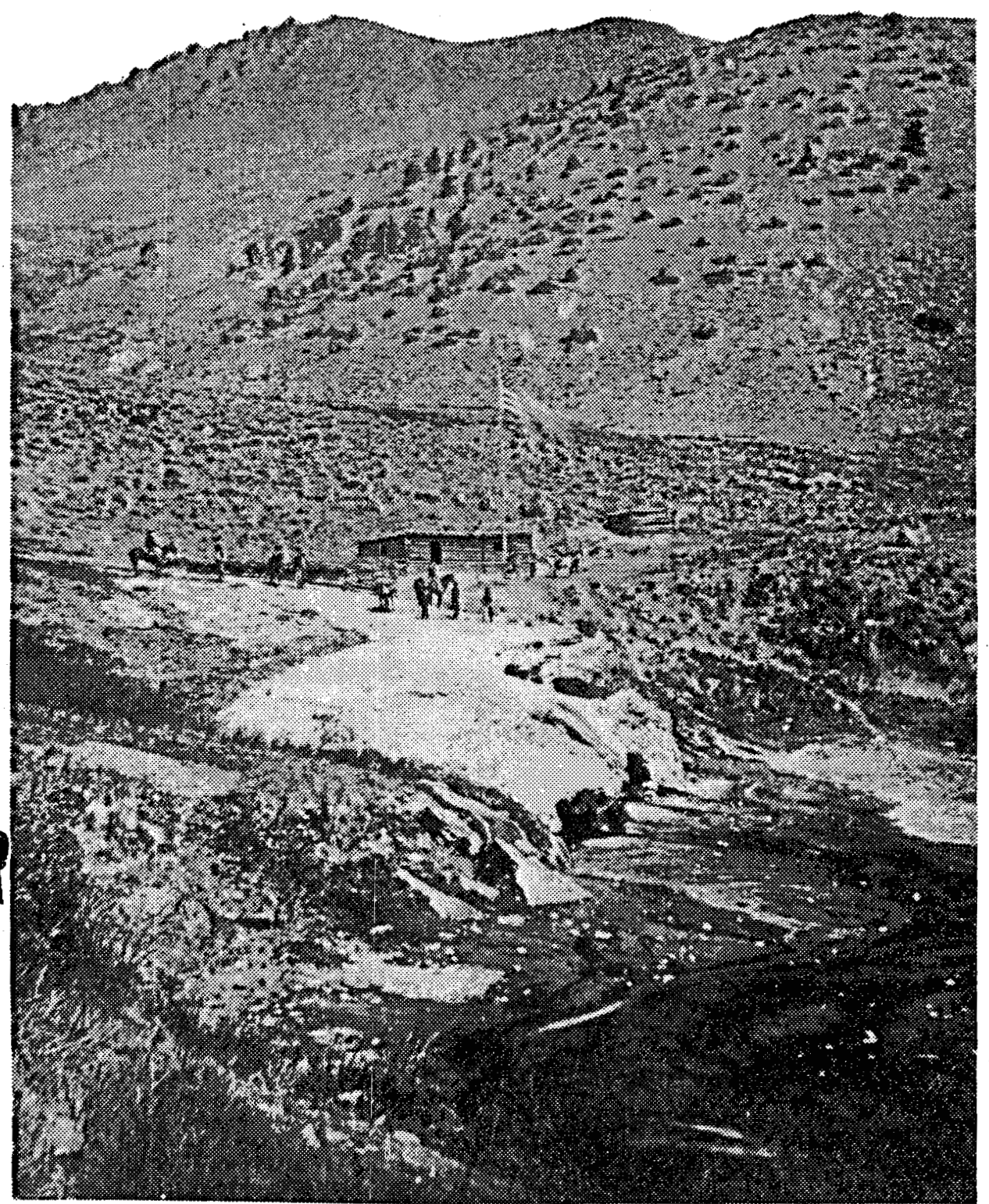




\section{DISCLAIMER}

This report was prepared as an account of work sponsored by an agency of the United States Government. Neither the United States Government nor any agency Thereof, nor any of their employees, makes any warranty, express or implied, or assumes any legal liability or responsibility for the accuracy, completeness, or usefulness of any information, apparatus, product, or process disclosed, or represents that its use would not infringe privately owned rights. Reference herein to any specific commercial product, process, or service by trade name, trademark, manufacturer, or otherwise does not necessarily constitute or imply its endorsement, recommendation, or favoring by the United States Government or any agency thereof. The views and opinions of authors expressed herein do not necessarily state or reflect those of the United States Government or any agency thereof. 


\section{DISCLAIMER}

Portions of this document may be illegible in electronic image products. Images are produced from the best available original document. 
DE84 012500

DOE/ET/28365-23

\title{
RESOURCE SERIES 23
}

\section{GEOTHERMAL RESOURCE ASSESSMENT OF HOT SULPHUR SPRINGS, COLORADO \\ by}

\author{
Richard Howard Pearl \\ Ted G. Zacharakis \\ Charles D. Ringrose
}

\section{DISCLAIMER}

This report was prepared as an account of work sponsored by an agency of the United States Government. Neither the United States Government nor any agency thereof, nor any of their employees, makes any warranty, express or implied, or assumes any legal liability or responsibility for the accuracy, completeness, or usefulness of any information, apparatus, product, or process disclosed, or represents that its use would not infringe privately owned rights. Reference herein to any specific commercial product, process, or service by trade name, trademark, manufacturer, or otherwise does not necessarily constitute or imply its endorsement, recommendation, or favoring by the United States Government or any agency thereof. The views and opinions of authors expressed herein do not necessarily state or reflect those of the United States Government or any agency thereof.

Prepared by the

COLORADO GEOLOGICAL SURVEY

in cooperation with the

U.S. Dept. of Energy

Under Contract No. DE-AS07-77EJ28365

\author{
Colorado Geological Survey \\ Department of Natural Resources \\ State of Colorado \\ Denver, Colorado \\ 1982
}

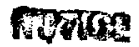

PUTTIONS OF THIS REPOPT AGE TLETELE

thas been reproduced from the best available copy to permit the troadest possible availability.
} 


\section{NOTICE}

This report was prepared to document work sponsored by the United States Government. Neither the United States nor its agent the United States Department of Energy, nor any Federal Employees, nor any of their contractors, subcontractors or their employees, makes any warranty, express or implied, or assumes any legal liability or responsibility for the accuracy, completeness, or usefulness of any information, apparatus, product or process disclosed, or represents that its use would infringe privately owned rights.

\section{NOTICE}

Reference to a company product name does not imply approval or recommendation of the product by the Colorado Geological Survey nor the U.S. Department of Energy to the exclusion of others that may be suitable.

\section{ACKNOWLEDGMENTS}

The authors are very grateful for the assistance of the following competent individuals: Robert Fargo, geophysical survey field crew chief; John Memmi and Bard Strong, geophysical survey field assistants; Carol Gerlitz, geochemical field crew chief and her assistant John Bradbury; Becky Nel son, typist; and Cheryl Brchan and Etta Norwood, who patiently drafted and redrafted the maps.

The manuscript was reviewed by Dr. Duncan Foley and Carl A. Ruscetta Earth Science Lab., University of Utah Research Institute. Their criticism and suggestions greatly improved the paper. The authors are deeply appreciative of their help and suggestions; however, the reader should be assured that all errors and omissions are the authors'.

Cover photo: Hot Sulphur Springs circa 1871. (Photo courtesy Coloradp Historical Society). 


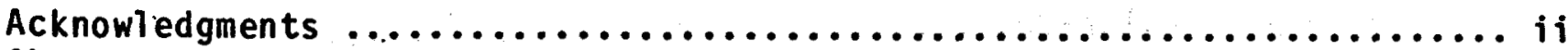

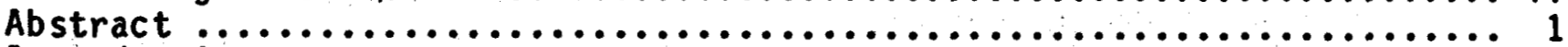

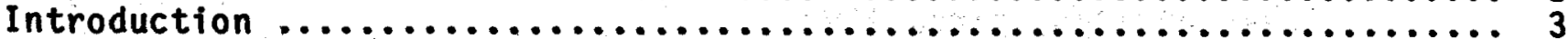

Thermal conditions of the Hot Sulphur Springs area................. 6

Thermal waters...................................... 6

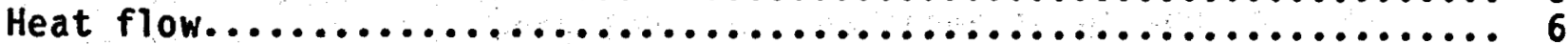

Geology $\ldots \ldots \ldots \ldots \ldots \ldots \ldots \ldots \ldots \ldots \ldots \ldots \ldots \ldots \ldots \ldots \ldots \ldots \ldots \ldots \ldots \ldots \ldots \ldots \ldots . \ldots 8$

Introduction $\ldots \ldots \ldots \ldots \ldots \ldots \ldots \ldots \ldots \ldots \ldots \ldots \ldots \ldots \ldots \ldots \ldots \ldots \ldots \ldots \ldots$

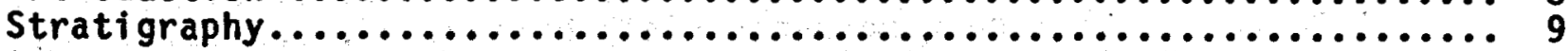

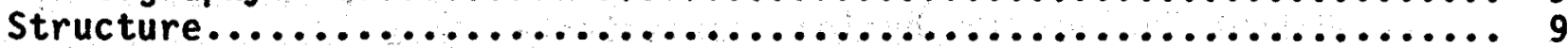

Hydrogeology of the Hot Sulphur Springs thermal water...............11

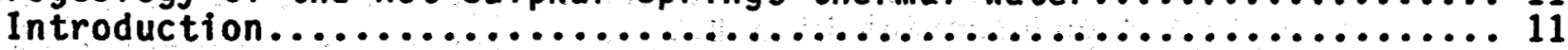

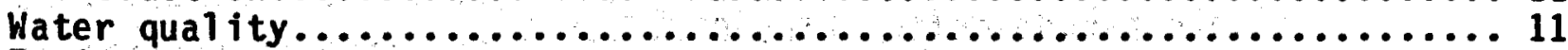

Estimated size and extent of thermal system................... 11

So il Mercury investigations $\ldots \ldots \ldots \ldots \ldots \ldots \ldots \ldots \ldots \ldots \ldots \ldots \ldots \ldots \ldots \ldots \ldots \ldots \ldots \ldots 12$

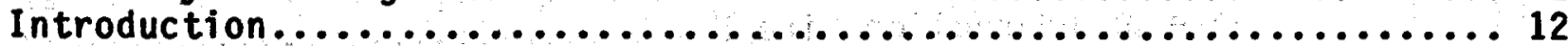

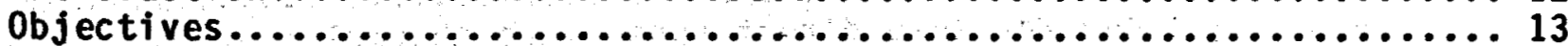

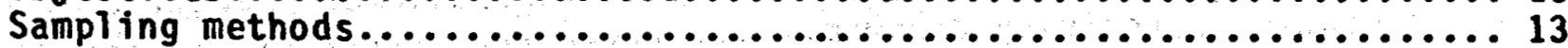

Background vs anomaly .................................. 14

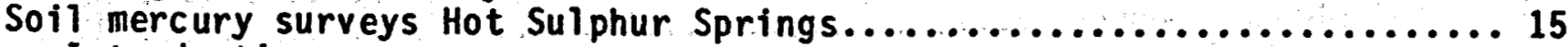

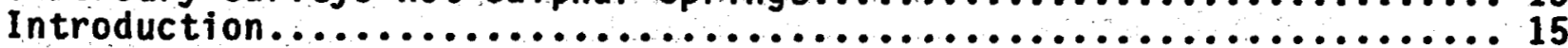

Soil description..................................... 15

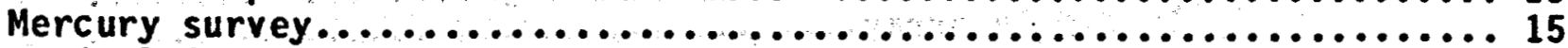

Electrical Geophysical Resistivity Survey ....................... 18

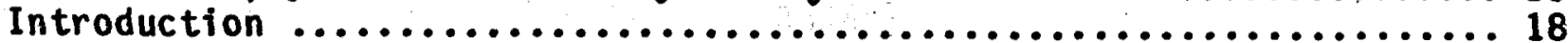

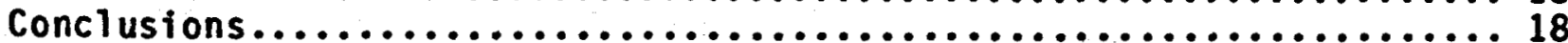

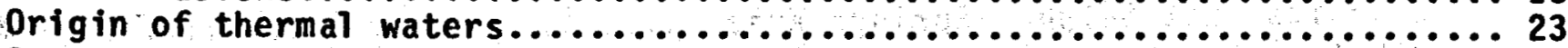

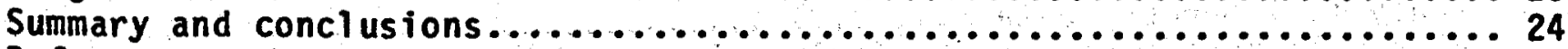

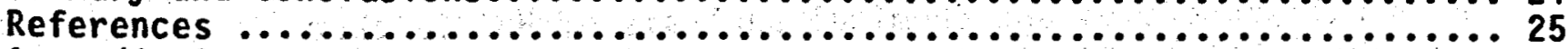

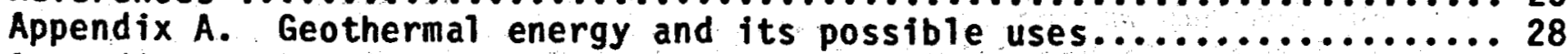

Appendix B. Physical properties and chemical analysis of Hot Sulphur

Appendix $C$. Factors affecting resistivity $\ldots \ldots \ldots \ldots \ldots \ldots \ldots \ldots \ldots \ldots \ldots \ldots \ldots \ldots$

Appendix D. Instrumentation

Scintrex $R A C-8$ low frequency resistivity system......... 33

Appendix E. Resistivity field procedures

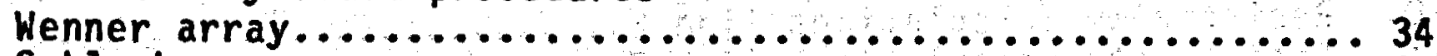

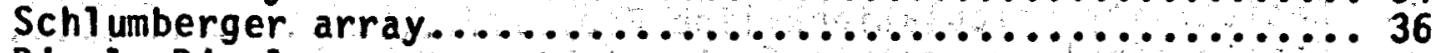

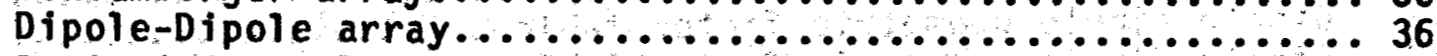

Appendix $F$. Resistivity calculations $\ldots \ldots \ldots \ldots \ldots \ldots \ldots \ldots \ldots \ldots \ldots$

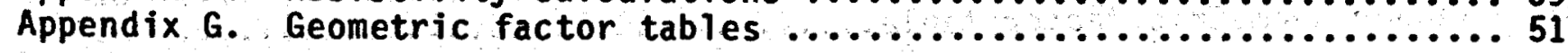


Fig. 1. Index map of Colorado.............................. 3

2. Geology and thermal springs $\ldots \ldots \ldots \ldots \ldots \ldots \ldots \ldots \ldots \ldots \ldots, 4$

3. Hot Sulphur Springs, circa $1899 \ldots \ldots \ldots \ldots \ldots \ldots \ldots \ldots \ldots \ldots \ldots, 5$

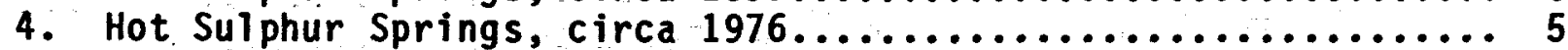

5 Prel iminary heat flow map of Colorado..................6. 6

6. Index map showing basement complex, Colorado.............8 8

7. Location of soil mercury sample sites, Hot Sulphur Springs

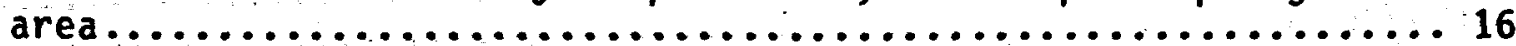

8 So il mercury anaiytical frequency distribution............. 17

9. Hot Sulphur Springs geophysical resistivity lines........... 19

10. Dipole-dipole pseudosection Line A..................... 20

11. Dipole-dipole pseudosection Line B...................... 20

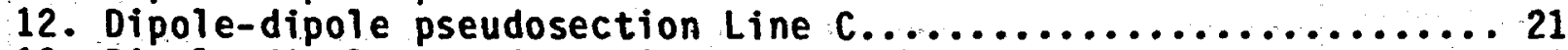

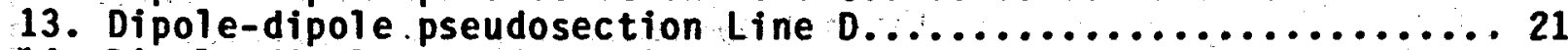

14 Dipole-dipole pseudosection Line E....................... 22

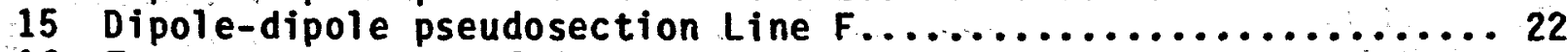

16. Temperature range for some direct uses of geothermal energy...2 29

17. Schematic resistivity diagram.......................... 35

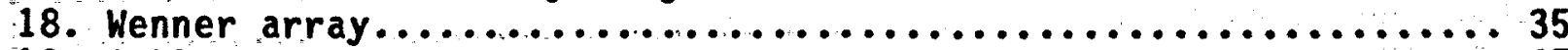

19. Schl umberger array................................... 37

20. Dipole-dipole array ................................. 37

21. Data plotting scheme for dipole-dipole array............. 38

22. Typical dipole-dipole array.......................... 38

\section{TABLES}

1. Rock units, Hot Sulphur Springs area.................... 10

2. Analytical mercury data................................ 17

3. Physical properties and chemical analysis of Hot Sulphur

Springs thermal waters............................... 30

4. Trace elements in Hot Sulphur Springs thermal waters.......... 31

5. Associated radioactivity, Hot Sulphur Springs thermal waters.... 31

6. Resistivity calculations 1 ine A......................... 39

7. Resistivity calculations line B......................... 41

8. Resistivity calculations line C.......................... 43

9. Resistivity calculations line D........................ 45

10. Resistivity calculations line E........................ 47

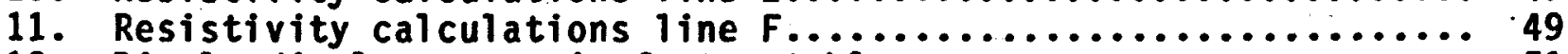

12. Dipole-dipole geometric factor table $\ldots \ldots \ldots \ldots \ldots \ldots \ldots \ldots \ldots \ldots, 51$

13. Dipole-dipole geometric factor table.................... 51

14. Wenner geometric factor table........................ 51 
GEOTHERMAL RESOURCE ASSESSMENT OF HOT SULPHUR SPRINGS, COLORADO

Richard Howard Pearl, Ted G. Zacharakis, and Charles D. Ringrose

\section{ABSTRACT}

In 1979. The Colorado Geological Survey, in cooperation wi th the U.S. Dept. of Energy, initiated a program to evaluate the resource potential of those thermal areas in Colorado having potential for near term development. One of the areas investigated was Hot Sulphur Springs in northwest Colorado. Approximately.10 springs whose waters are used for recreation, steam baths and 1 aundry purposes are located at Hot Sulphur Springs:

Estimated heat-flow at Hot Sulphur Springs is approximately $100 \mathrm{~mW} / \mathrm{m} 2$, which is about normal for western Colorado. Recent work tends to show that surface and reduced heat flow in the mountains of northern colorado could be high.

Hot Sulphur Springs is located approximately in the center of Middle Park, a large intermountain, synclinal basin located between the Front Range on the east and the Park-Gore Range on the west. Precambrian igneous and metamorphic rocks are exposed less than a mile southwest of the springs in Byers Canyon. Unconformably overlying these rocks and dipping to the northeast is a sequence of sedimentary rocks over $10,000 \mathrm{ft}(3.1 \mathrm{~km})$, thick ranging in age from Jurassic to Recent, which are deformed by two faults. The Mount Bross Thrust Fault is located within one-half mile northeast of the springs and a small normal fault is just west of the springs.

The thermal waters have an estimated discharge of $50 \mathrm{gpm}$, a temperature that ranges from $104^{\circ} \mathrm{F}\left(40^{\circ} \mathrm{C}\right)$ to a high of $111^{\circ} \mathrm{F}\left(44^{\circ} \mathrm{C}\right)$, and a total dissolved solid content of $1,200 \mathrm{mg} / 1$. The waters are a sodium bicarbonate type with a large concentration of sulphate. It is estimated that the most likely reservoir temperature of this system ranges from $167^{\circ} \mathrm{F}\left(75^{\circ} \mathrm{F}\right)$ to $302^{\circ} \mathrm{F}\left(150^{\circ} \mathrm{C}\right)$ and that the areal extent of the system could encompass $1.35 \mathrm{sq} \mathrm{mi}(3.50 \mathrm{sq} \mathrm{km})$ and could contain 0.698 Q's (1015 B.T.U.'s) of heat energy.

To aid in the evaluation of this system, soil mercury and electrical resistivity surveys were conducted. Unlike other areas of colorado, the soil mercury survey proved less than satisfactory in helping to delineate the geological conditions controlling the occurrence of the thermal waters.

The geophysical survey delineated several areas of low resistivity associated with the north trending fault that passes just to the west of the spring area. It appears that this fault is saturated with thermal waters and may be the conduit along which the thermal waters are moving up from depth. From the evidence gathered, the Mount Bross Fault does not appear to control the occurrence of the springs.

While no deep hydrogeological information is available, it appears that the Hot Sulphur Springs thermal waters represent deep circulation of meteroric waters along numerous faults and fractures in an area of above normal heat flow. Recharge to the system probably occurs on the high ground to the east. 
It is not possible to make any accurate predictions concerning required circulation depths due to the thick sequence of insulating Pierre shale found in the area. Due to the presence of this unit it is possible that low-to moderate-temperature waters $158^{\circ} \mathrm{F}-212^{\circ} \mathrm{F},\left(70^{\circ} \mathrm{C}-100^{\circ} \mathrm{C}\right)$ could be found at its base.

The appendecies to this report include tables showing water temperatures required for various industrial processes, as well as dissolved minerals, trace elements and radioactivity levels found in the thermal waters. Also presented are a complete description of the factors affecting the electrical resistivity measurements, a description of the electrical resistivity equipment used, and the resistivity field procedures. Electrical resistivity calculations are also included in the appendecies. 


\section{INTRODUCTION}

In 1979, the Colorado Geological Survey, in cooperation with the U.S. Department of Energy, Division of Geothermal Energy, initiated a program to delineate the geological features controlling the occurrence of those geothermal resources in Colorado believed to have a high potential for near term development. This effort consisted of a literature search, geologic and hydrogeological mapping, geophysical surveys, and soil mercury geochemical surveys. The areas evaluated under this program were: The Animas Valley, north of Durango; Canon City Area; Hartsel Hot Springs; Hot Sulphur Springs; Idaho Springs; Ouray; Ranger Hot Springs; Shaws Spring, western San Luis Valley; and Steamboat-Routt Hot Springs.

This report presents the geothermal resource assessment efforts conducted in and around the community of Hot Sulphur Springs in Grand County. Hot Sulphur Springs is a community of approximately 405 persons, located on the Colorado River 97 miles $(156 \mathrm{~km})$ northwest of Denver (Fig. 1). In this area there is a group of thermal springs located just to the northwest of the town on the north side of the Colorado River. (Fig. 2). The springs are privately owned and are used for swimming, steam baths and laundry purposes.

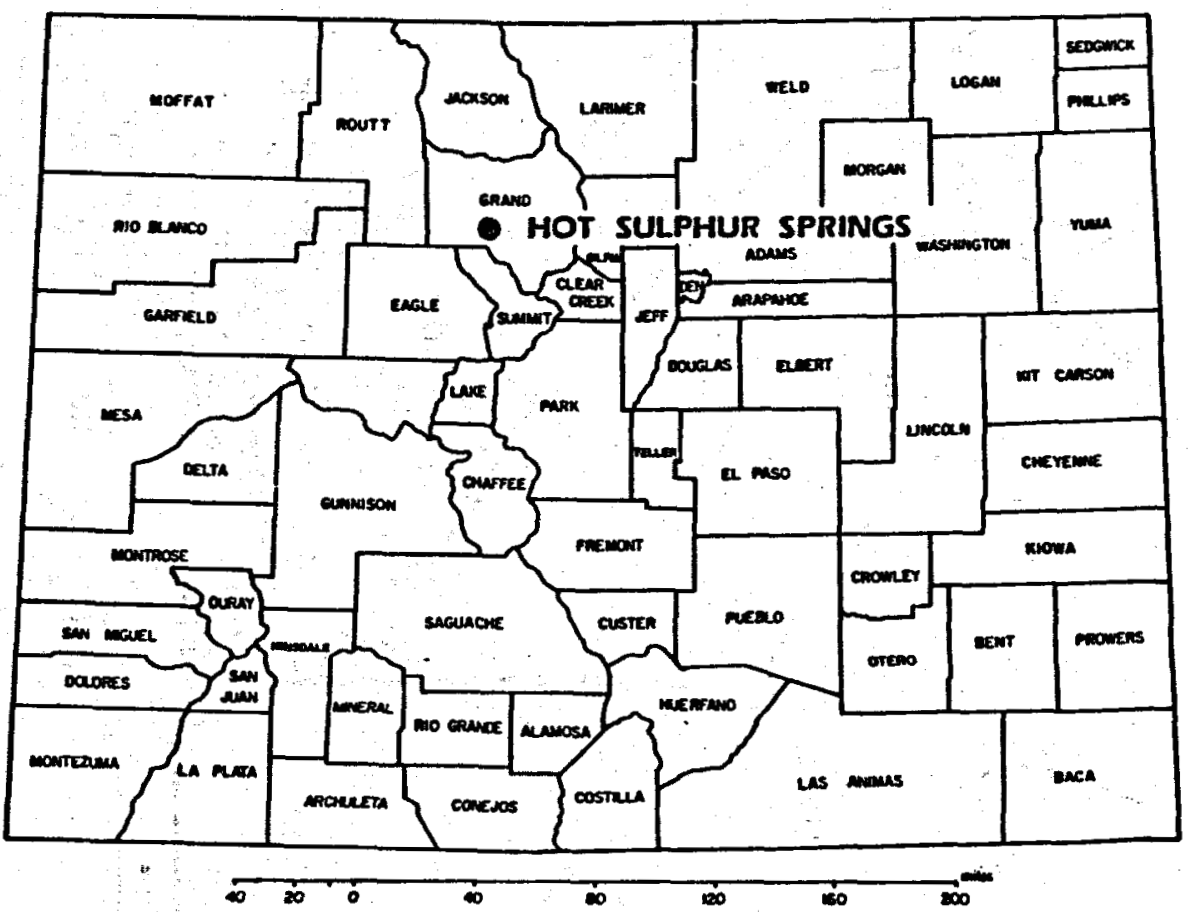

Figure 1. Index map of Colorado.

This study was necessitated by the fact that geothermal energy, the natural heat of the earth, is a viable al ternative source of energy that can be put to a wide range of uses. Normally, geothermal energy is either too diffuse or found at depths too great to be of practical value. However, in some instances, where it is occurs close to the surface, it can be developed and put to practical use with readily available techniques and equipment. A brief description of geothermal energy and some of the uses it can be put to are presented in Appendix A. 


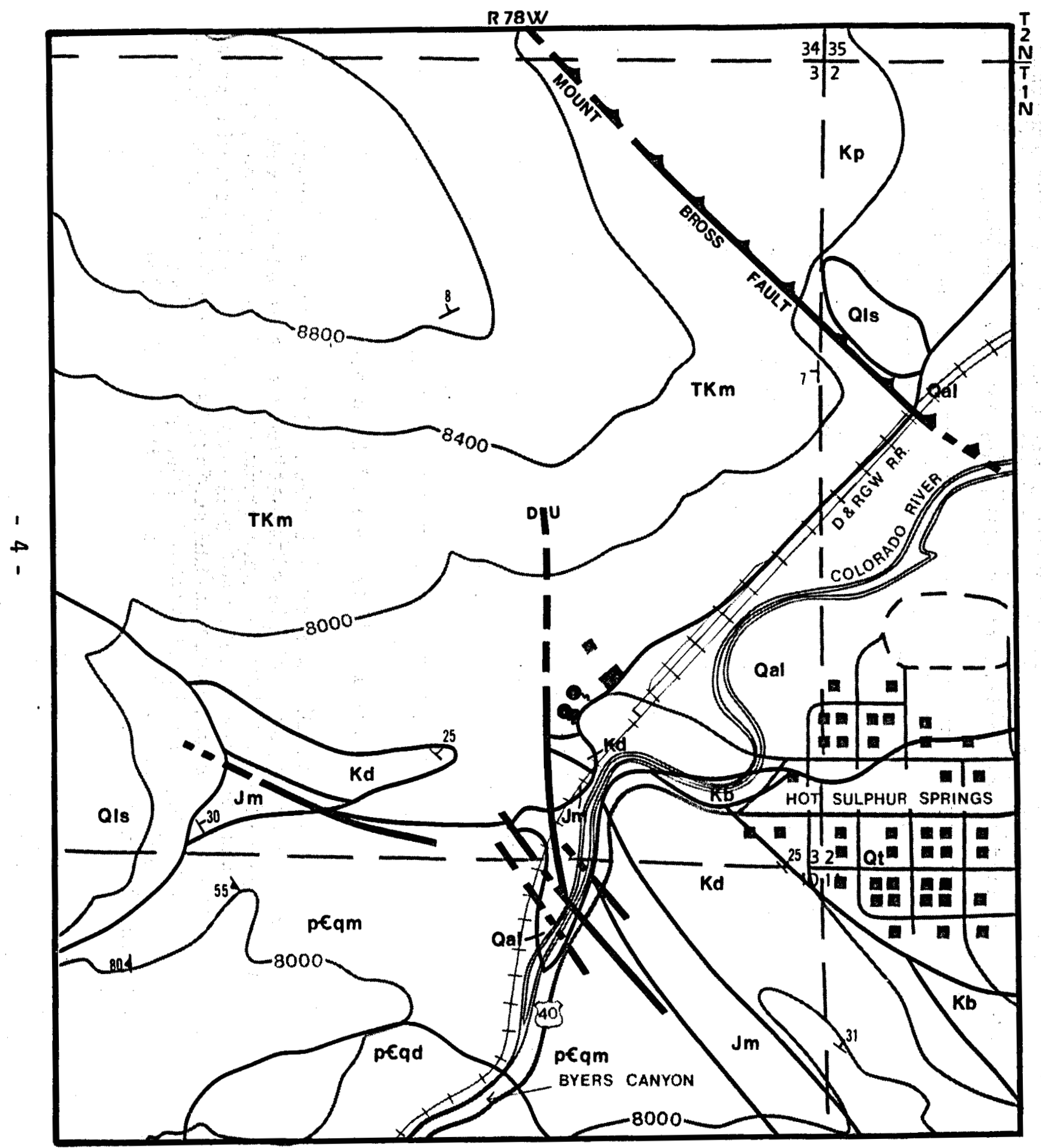

\section{EXPLANATION}

Qal Quaternary alluvium

Qls Quaternary landsije

Qt Quaternary terrace grave

TKm Tertiary-Cretaceous Middle Park Formation

Kp Cretaceous Pierre Shale

Kn Cretaceous Niobrara Fm.

Kb Cretaceous Benton Shale

Kd Cretaceous Dakota Group

Jm Jurassic Morrison Fm.

peqm Precambrian quartz monzonite

peqd Precambrian quartz diorite

- Geologic contact

- Fault, dashed where inferred, dotted where concealed

- High angle reverse fault, sawteeth on upper plate. dashed where inferred, dotted where concealed

$\stackrel{5}{5}$ Strike and dip of beds

I Strike and dip of foliation

a Hot spring
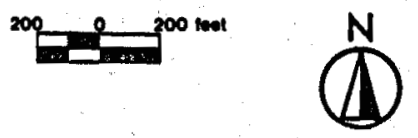

Base modified from U.S.G.S.

$7 \frac{1}{2}$ ' topographic quadrangle map.

Figure 2. Geology and thermal springs, Hot Sulphur Springs area (Geology modified from Izett and Hoover, 1963). 


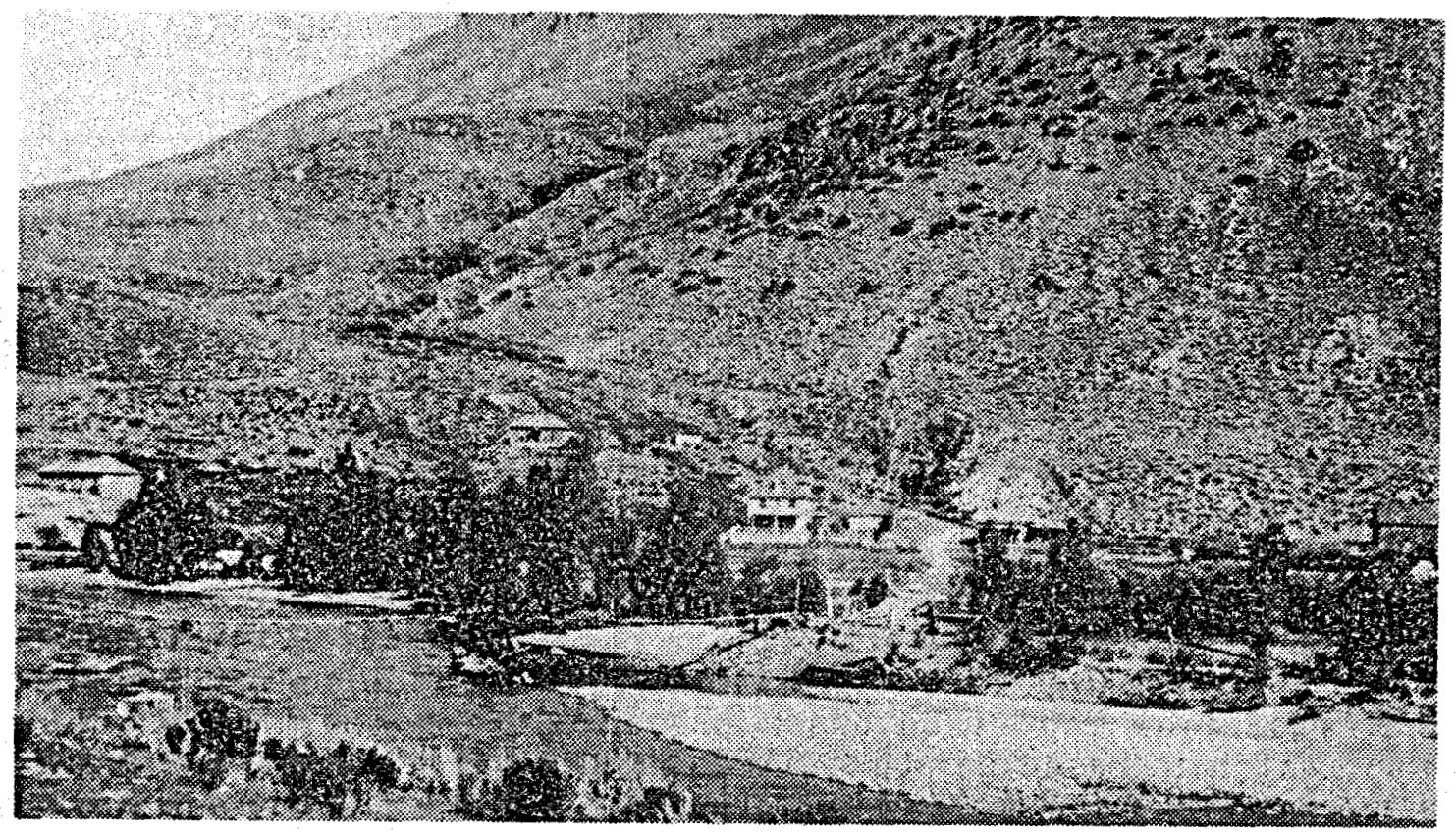

Figure 3. Hot Sulphur Springs circa 1899. Hot springs located at extreme left center of photo. (Photo courtesy of Colorado Historical Society.)

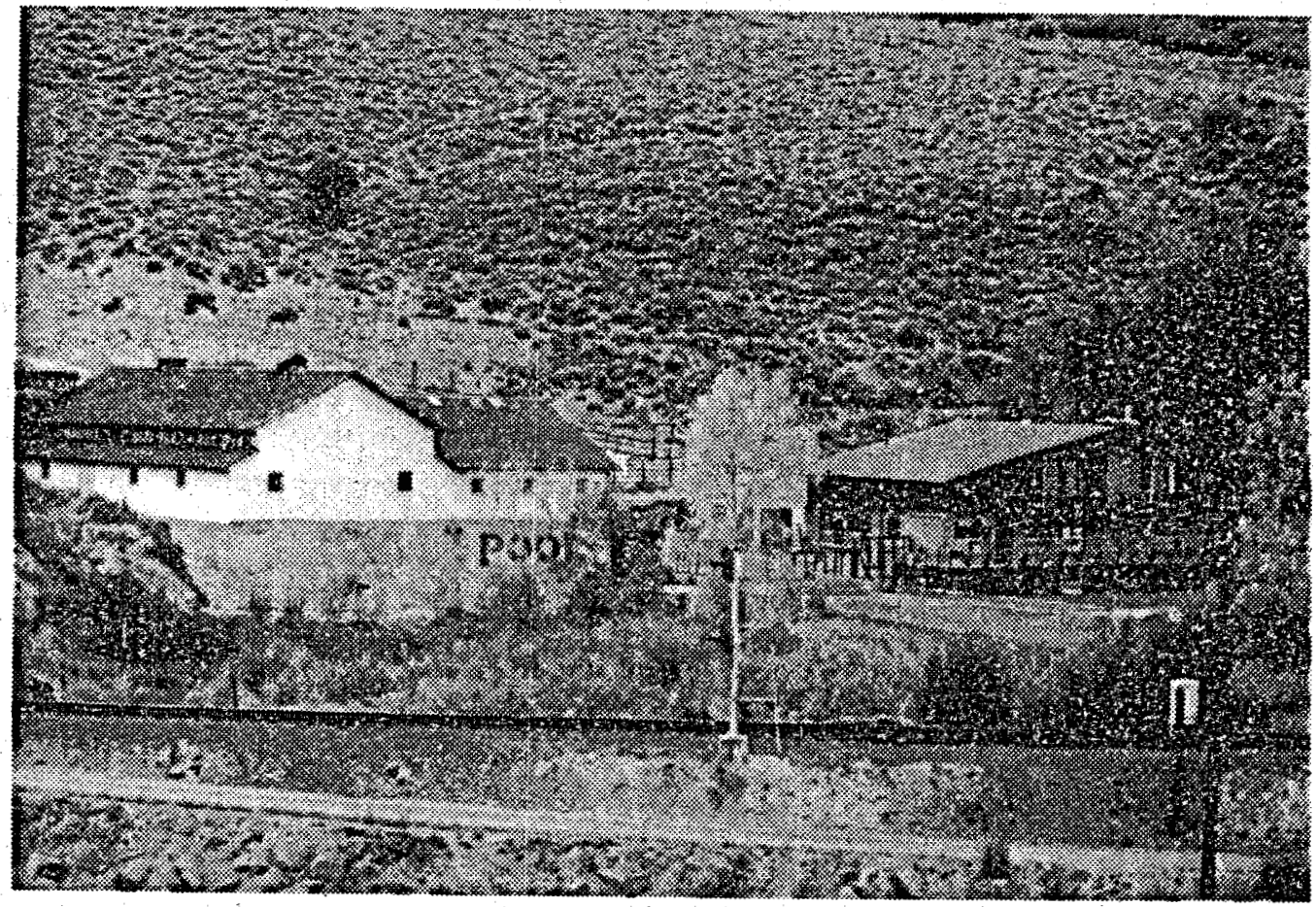

Figure 4. Hot Sulphur Springs circa 1976. Springs located to rear and left of white building. 
Thermal Waters

A11 the thermal waters in the Hot Sulphur Springs area are located at the resort across the Colorado River from the community by the same name. The springs issue from a large travertine mound north of the main resort buildings and in a marshy area to the west. The thermal waters range in temperature from $104^{\circ} \mathrm{F}\left(40^{\circ} \mathrm{C}\right)$ to $111^{\circ} \mathrm{F}\left(44^{\circ} \mathrm{C}\right)$. Due to modification of the spring's discharge point it is hard to determine accurately just how many springs exist, but there appear to be 5-10 individual springs.

\section{Heat Flow}

No measurements of heat-flow have been made in the vicinity of Hot Sulphur Springs, however the best estimate of the heat-flow in this region is the regional heat-flow map of Colorado prepared by Zacharakis (1981) (Fig. 3 ). This map, which is based on approximately 45 published heat-flow values, shows that the estimated heat-flow at Hot Sulphur Springs is approximately 100 $\mathrm{mW} / \mathrm{m} 2$, which is normal for western Colorado.

While the Middle Park region of Colorado is not normally thought to have high heat-flow, recent work by Decker and others (1981) of the University of Wyoming showed that surface and reduced heat flow in the mountains of Wyoming along the Wyoming-Colorado border is low to normal, while that in the mountains of northern Colorado, including North and Middle Parks, is high.

Buelow (1980) noted that these parks could be a high heat-flow area similar to the Rio Grande Rift in southern New Mexico and west Texas. In attempting to explain this, Decker and others (1981) suggested two interpretations: "First, the unrealisticially high calculated temperatures suggests that the flux may be explained by transient conductive or nonconductive heat sources in the subsurface. Secondly, the heat sources that produce the excess flux must be in the crust because the depicted northern border of the anomaly is narrow $(<50 \mathrm{~km})$ ". They (Decker and others, 1981) noted the cooling of a low density rock body at a depth between 16,404 and

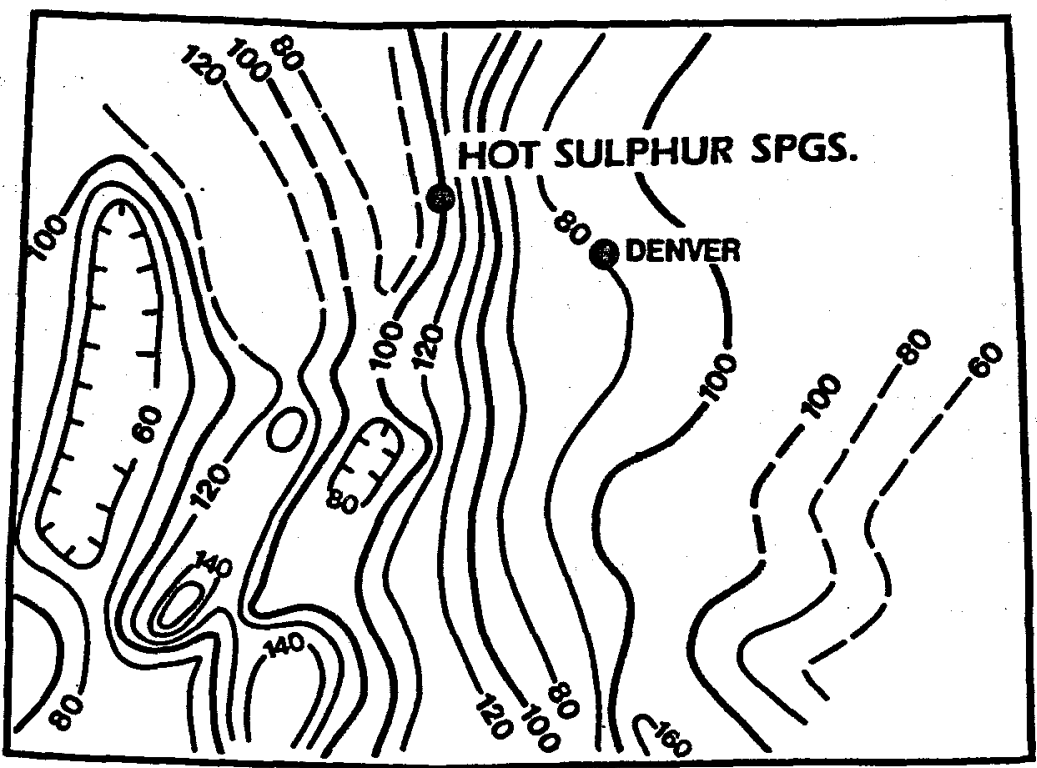

Figure 5. Preliminary heat flow map of Colorado (Adopted from Zacharakis, (1981.) 
$32,808 \mathrm{ft}(5$ and $10 \mathrm{~km})$ in the upper crust would al so explain the high heat flow if they were emplaced about 2 million years ago at intrusion temperatures of $1,112-1,292^{\circ} \mathrm{F}\left(600-700^{\circ} \mathrm{C}\right)$.

Decker and others (1981) stated that due to the following reasons high heat-flow might not be restricted to a simple north-south trending zone but might be found throughout the area: Late Miocene age volcanic rocks are found in the Elkhead Field; relatively young ( $>2$ million year old) igneous rocks are found throughout the western and central parts of western colorado in the Basalt Mountain-Flat Tops-State Bridge area; and the high heat flow at Hahn's Peak. They al so pointed out that the high heat-flow of North and Middle Park suggest that these areas could be underal in by hot dry rock resources. (Decker and others, 1981). The most favorable area for these resources would be in the Basalt Mountain-Flat Top-State Bridge area southwest of the Hot Sulphur Springs area.

Decker and others (1981) felt that if the geological conditions were right that moderate to high temperature thermal waters suitable for the generation of electricity could be found in some parts of North and Middle Parks. They al so believed that there was a good chance for the development of these higher temperature resources in the Basalt Mountain-Flat Top-State Bridge area, southwest of Hot Sulphur Springs. 


\section{GEOLOGY}

\section{Introduction}

Hot Sulphur Springs is located approximately in the center of Middle Park, a large intermontaine basin just west of the Continental Divide (Fig. 4). Middle Park is bounded on the west by the Park-Gore Range, on the north by a low range of hills called the Rabitt Ears Range, which divides Middle Park from North Park, and on the east and south by the Contiental Divide. Unlike the other two large intermontaine basins in Colorado, North and South Parks, Middle Park from the ground appears to be quite irregular and rough. It is only from the air that the open nature of the land is apparent. When viewed from the air it appears that North and Middle Park are really one large basin, and they are often refered to as the North-Middle Park region.

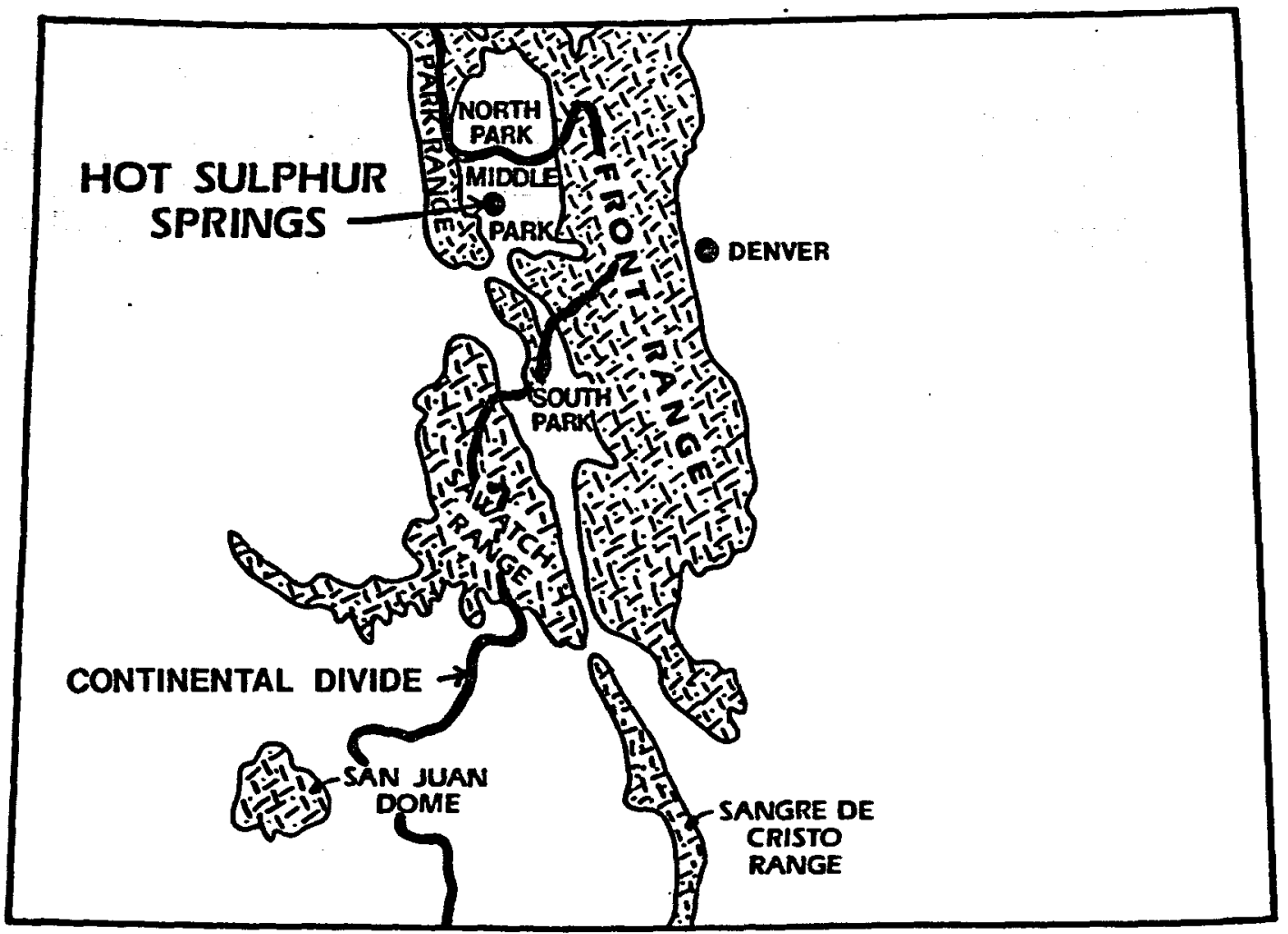

Figure 6. Index map showing basement complex, Colorado.

Several comprehensive papers have been written describing the geological conditions of the Hot Sulphur Springs region. Izett (1968 and 1975) and Izett and Hoover (1963) described the geological conditions of the Hot Sulphur Springs area in depth, while Steven (1975) described in general terms the volcanic rocks found in the area. Tweto (1975) presented a discussion on the tectonic development of the region. The following discussion is taken from these papers.

Middle Park, like many of the other structural features of western Colorado, developed as a result of mountain building forces during the Laramide Orogeny which extended from Late Cretaceous to early Tertiary time. The mountains and several major basins of northern colorado and southern Wyoming 
developed on the site of the late Paleozoic Ancestral Front Range. One of these basins is the North-Middle Park basin, a synclinal basin between the Front Range on the east and the Park-Gore Range on the west. As this basin had little or no pre-Laramide expression, the sedimentary rock sequence in it is not exceptionally thick.

The low range of hills dividing North and Middle Parks, the Rabbit Ears Range, is capped by a sequence of mafic, intermediate, and silicic volcanic rocks that are cut by a series of volcanic necks and intrusive structures that mark the roots of ancient volcanoes (Steven, 1975). Most of the volcanic rocks have been dated as 01 igocene and Miocene(?) age and are included in the Rabbit Ears Volcanics.

\section{Stratigraphy}

As shown on Fig. 2 Precambrian igneous and metamorphic rocks are exposed less than one mile southwest of town in Byers Canyon. Unconformably overiying these rocks and dipping to the northeast is a sequence of sedimentary sandstones, siltstones, shales, and limestones belonging in ascending order to the Morrison, Dakota, Benton, Niobrara, and Pierre Formations. Overiying these formations, with angular unconformity, is the Tertiary Middle Park Formation consisting of lava flows and associated siltstone and sandstones. Table 1 presents a brief description of the rock units found in the Hot Sulphur Springs area.

\section{Structure}

Less than one-half mile northeast of the hot springs is the Mount Bross Fault, a major high angle northwest-trending reverse fault. In the vicinity of the hot springs the Mount Bross Fault has brought Pierre Shale into contact with the Middle Park Formation. This fault does not appear to control the occurrence of the springs, since they are located just east of a small north trending normal fault (Fig. 2). This small fault is well exposed in a roadcut near the northern end of Byers Canyon where it cuts the Morrison Formation. The thermal waters may be ascending along this fault zone. Not shown on Figure 2 because it is off the map, is an east-west thrust fault which Izett (1968) shows terminating approximately one mile west of the springs. 


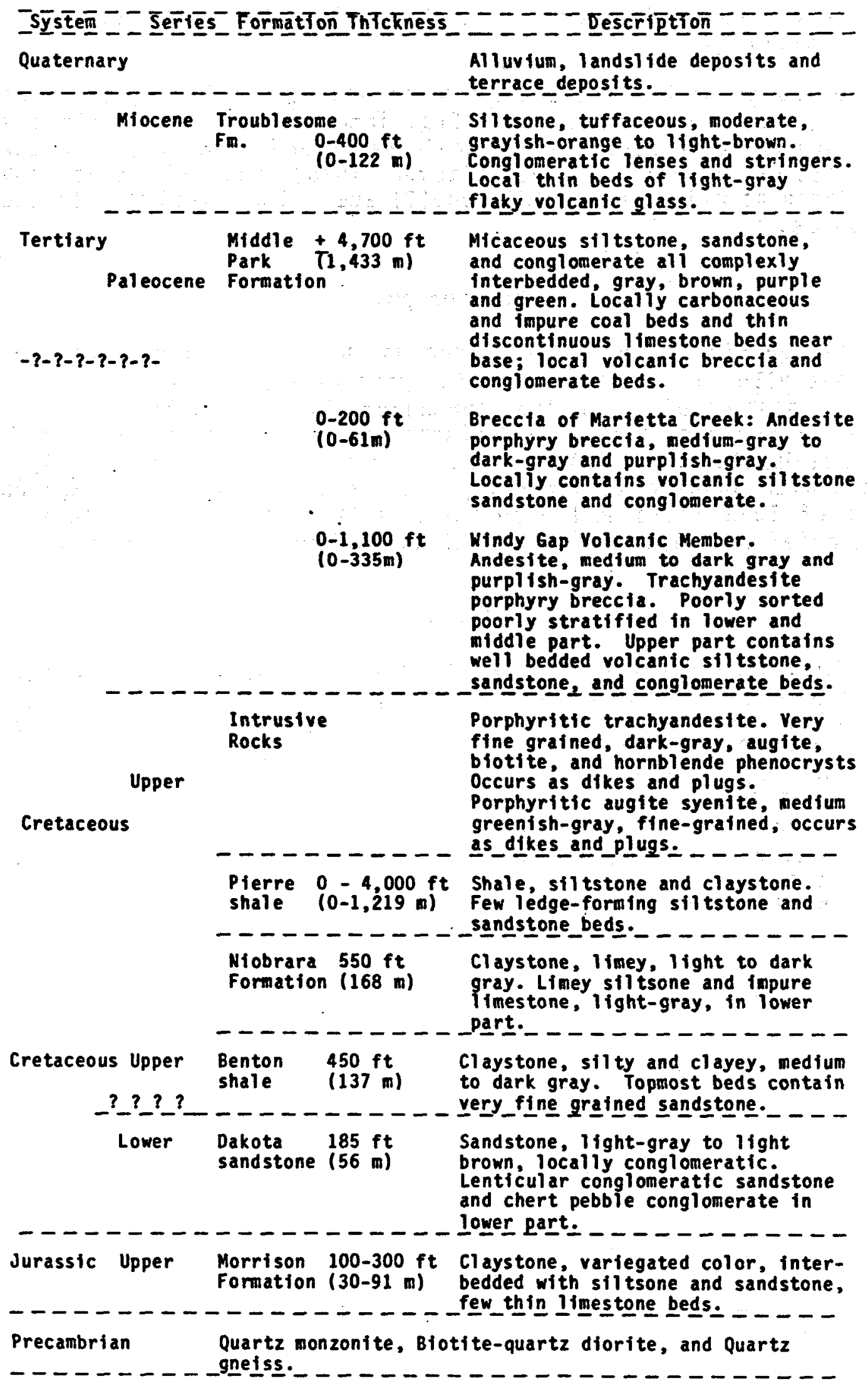




\section{Introduction}

Al1 the thermal waters in the Hot Sulphur Springs area are found at the resort across the Colorado River from the town of Hot Sulphur Springs (Fig. 2). On the hillside behind the resort is a large deposit of grayish travertine approximately $200 \mathrm{ft}(61 \mathrm{~m})$ in diameter and perhaps $40 \mathrm{ft}(12 \mathrm{~m})$ thick. Some of the thermal waters issue from the travertine while others issue around the swimming pool building. Due to the construction of an extensive collection system through which the waters are piped into the resort buildings, it is impossible to accurately determine the exact number of springs present. However, it appears that there may be as many as 10 springs. The waters are used for a wide variety of purposes in the resort.

The following authors have discussed in detail one or more aspects of this thermal system: Barrett and Pearl (1976 and 1978); Berry and others (1980); George and others (1920); Lewis (1966); Mallory and Barnett (1973); Peale (1886); Pear1 (1972 and 1979); and Waring (1965).

\section{Water Quality}

The springs have an estimated total discharge $50 \mathrm{gpm}$, a temperature that ranges from $104^{\circ} \mathrm{F}$ to $111^{\circ} \mathrm{F}\left(40^{\circ} \mathrm{C}\right.$ to $\left.44^{\circ} \mathrm{C}\right)$ and a total dissolved solid content of $1,200 \mathrm{mg} / 1$. The waters are a sodfum bicarbonate type with a large concentration of sulfate (Barrett and Pearl, 1976 and 1978). A complete list of all the dissolved mineral found in the thermal waters is presented in Appendix B. In addition, amounts of the various trace elements and radioactivity associated with the thermal waters are al so presented in Appendix $B$. The waters appear to be coming from the underlying Dakota sandstone.

\section{Estimated Size and Extent of Thermal System}

Based on geothermometer analysis Barrett and Pearl (1978) estimated that the most 1 ikely reservoir temperature of this system ranges from $167^{\circ} \mathrm{F}$ to $302^{\circ} \mathrm{F}$ $\left(75\right.$ to $150^{\circ} \mathrm{C}$ ). Due to the chemical composition of the thermal waters they noted that these estimates should be questioned because many of the assumptions the model s are based on are violated. Pearl (1979) estimated that the areal extent of the Hot Sulphur Springs thermal system could encompass $1.35 \mathrm{sq}$ mf ( $3.50 \mathrm{sq}$ $\mathrm{km})$ and could contain $0.698 \mathrm{Q}^{\prime} \mathrm{s}(1 \mathrm{Q}=1,000,000,000,000,000 \mathrm{BTU}$ 's) of thermal energy at a temperature of $104^{\circ} \mathrm{F}\left(40^{\circ} \mathrm{C}\right)$. 


\section{Introduction}

The majority of exploration methods used in geothermal exploration are the more common ones such as geology, geophysics, and hydrogeological mapping; however, new methods are beginning to be used. One of these, soil mercury surveys, has proven successful in a number of instances. For example Capuano and Bamford (1978), Cox and Cuff (1980), K1 usman and others (1977), K1 usman and Landress (1979), and Matlick and Buseck (1976) have demonstrated the use of soil mercury surveying as a geothermal exploration tool. Both Matlick and Buseck (1976), and more recently, Cox and Cuff (1980), have used soil mercury surveys on a regional scale. On a detailed scale, Kl usman and Landress (1979) and Capuano and Bamford (1978) have shown how soil mercury surveys can delineate faults or permeable zones in geothermal areas. The association of mercury with geothermal deposits has been shown by White (1967). Matilick and Buseck (1976) stated that areas with known thermal activity, such as the Geysers, California; Wairakei, New Zeal and; Geyser, Iceland; Larderel1o, Italy and Kamchatka, Russia contain mercury deposits.

Matlick and Buseck (1976), in presenting the geochemical theory behind the associations of mercury with geothermal deposits, noted that mercury has great volatility and the elevated temperatures of most geothermal systems tends to cause the element to migrate upward and away from the geothermal reservoir. In addition, they noted the work of white (1967), and White and others (1970) which showed that relative high concentrations of mercury are found in thermal waters. Matlick and Buseck (1976) then pointed out that soils in thermal areas should be enriched in mercury, with the mercury being trapped on the surfaces of clays and organic and organometallic compounds.

Matlick and Buseck (1976) presented 4 case studies where they used soil mercury concentrations as a exploration tool. Three of the four areas tested, Long Valley, California, Summer Lake, Oregon and Klamath Falls, Oregon, indicated positive anomailies. At the fourth area, East Mesa in the Imperiai Valley of California, no anomaly was observed al though isolated el evated values were recorded.

Klusman and others (1977) evaluated the soil mercury concentration at six geothermal areas in Colorado. These areas were Routt Hot Springs, Steamboat Hot Springs, Glenwood Springs, Cottonwood Hot Springs, Mt. Princeton Hot Springs, and Poncha Hot Springs. Their sampling and analysis procedures differ from Matlick and Buseck (1976) in that they first decomposed the soils using hydrogen peroxide and sulfuric acid; then a flameless atomic absorption procedure was used to determine the concentration of mercury. They presented the results for only one of the six areas sampled, Glenwood Springs. Their survey indicated anomalous zones but they noted that their data would require more analysis.

Soil Mercury surveys were run by Capuano and Bamford (1978) at the Roosevelt Hot Springs Known Geothermal Resource Area Utah. They analyzed the soil samples with a Jerome Instrument Corp. gold film mercury detector. The results of their investigation showed that mercury surveys can be useful for indentifying and mapping faults and other structures controlling the flow of thermal waters and for delineating areas overlying near-surface thermal activity. 


\section{Objectives}

The aim of the geochemical sampling program by the Colorado Geological Survey was to evaluate those thermal areas deemed to have high commercial development potential. As the time alloted for this program was limited, the soil mercury surveys had to be preliminary in nature. The geochemical sampling program started in 1979 and continued into 1980. The surveys conducted during the summer of 1979 were aimed at determining the structural conditions controlling the hot springs. This approach was strongly influenced by the results of Capuano and Bamford (1978). During 1980 a silightly broader target was considered, rather than just sampling along traverses located over suspected faults; grid sampling patterns were used where possible. If anomalous mercury concentrations were detected, then follow-up samples were collected at a more detailed level. For those thermal areas where grid sampling was not possible due to lack of access, soil disturbance, or urban development, traverses were chosen in a similar method to the procedure used in 1979.

During the course of the investigations several restrictions became apparent. One of these was soil disturbance caused by urban development. One cannot really be sure whether the surface deposits in the back streets and lawns are original or have been brought in. Another problem occurred frequently in sampling alluvial and colluvial surficial deposits; such deposits because of their origin, age and mineral content tend to mask, dilute, and/or distort any anomaltes.

\section{Sampling Methods}

At selected sample sites, one to elght samples were taken at points within 15 to $20 \mathrm{ft}(4.6 \mathrm{~m}$ to $6.1 \mathrm{~m})$ of each other. The notation of sampi ing locality is explained in Miesch (1976). The interval between sampling sites depends on the target being considered. For areas investigated, the sample site interval was either $100 \mathrm{ft}, 200 \mathrm{ft}$ or $400 \mathrm{ft} .(30.5 \mathrm{~m}, 61 \mathrm{~m}$ or $122 \mathrm{~m})$. When using a 400 $f t(122 \mathrm{~m})$ interval, the area in the immediate vicinity of the hot spring was considered the target rather than any particular fault. Sampling intervals of $200 \mathrm{ft}(61 \mathrm{~m})$ or less were used where attempts were made to delineate controlling faults. This.spacing was used by Capuano and Bamford: (1978). However, Kiusman and Landress (1979) seem to think that the sample must be taken directly over the faulting for detection. Considering the empirical result of Capuano and Bamford (1978), it was believed that some anomalous mercury values should be encountered if a grid pattern encompassing the hot spring area was used. A definite structural pattern may be obvious, but if the study area is being influenced by geothermal activity, the trend should indicate that the hot springs area is entirely or partially high in mercury relative to the surrounding area.

The sampling procedure used during 1979 consisted of laying out a series of sample lines across suspected faults in the thermal areas. Samples were then collected at predetermined intervals (usually $100 \mathrm{ft}$ ) along the 1 ines.

In most of the areas investigated during 1980, three or more samples were taken at random sample localities. This was done to get an estimate of how the variance between sample localities compared with the variance at a sample locality. If the comparison suggested that there is as much variance at a sample locality as there is between sample localites, then the data would be interpreted on a point to point basis. Contouring the data would more than likely lead to fal se interpretation. 
Two rationales have been used for determining the sampling depth. The method recommended by Cupuano and Bamford (1978) is to determine the profile of mercury down to a depth of approximately 15 in $(38 \mathrm{~cm})$; the depth at which the profile peaks determines the sampling depth. The other method consistently samples a soil horizon, such as the $A$ or B horizon. The problem with using the A horizon is that its normally high organic content has been shown to have strong secondary effects in controlling mercury in the soil. Also, the sampling depth in the A horizon may not be deep enough to avoid the "baking" effect of the sun.

The method used during 1979 consisted of using profiles to determine sampling depths. A sampling depth of approximately 6 in $(15.2 \mathrm{~cm})$, with an interval of about 4 in $(1 \mathrm{~cm})$, was used for most of the profiles. During 1980, each sample was taken over an interval of 5 to 7 in $(13$ to $18 \mathrm{~cm})$. It was hoped that some of variance due to depth would be smoothed out by sampling over a wider interval. Also at that depth it was hoped that the sun would not be affecting the soil's ability to retain mercury.

To collect a sample, the ground was broken with a shovel to a depth of 8 to 10 in $(20$ to $25.4 \mathrm{~cm})$. A spatula and metal cup were then used to collect approximately 100 grams of material. The contents of the cup were then put. in a marked plastic bag. At the end of the day the material in each bag was laid out and allowed to dry over night. Sometimes it would take more than one night to dry. Normally, the following morning the dried material would be sieved down to an 80 mesh size, outside in a shaded area, and stored in $4 \mathrm{ml}$ glass vials with screw caps. Within a period of 7 days, the samples were anaiyzed for mercury using the Model 301 Jerome gold film mercury detector.

\section{Background vs Anomaly}

For an accurate analysis of geochemical data it is necessary to differentiate between background and anomalous values. There are various statistical ways of accomplishing this. For those areas where the statistical sample approaches 100 samples and a lognormal distribution can be assumed, a method wich looks for a break in the accumulative frequency plot of the mercury data can be used. Hopefully, the break distinguishes the two populations - the background and the geothermal induced population (Cupuano and Bamford, 1978; Lepel itor, 1969; Levinson, 1974).

For those instances where the data were analyzed using a cumulative frequency diagram, the following procedure was used.

1). Determine the number of class intervals by multiplying the logarithm of the sample by 10 .

2). Determine the range of each class interval by dividing the maximum recorded value, determined above, by one less.

3). Determine logarithm of top end of each interval.

4). Determine class frequency by calculating the number of values in each class. 
5). Determine relative frequency by dividing each class frequency value by total number of values.

6). Construct frequency distribution graph by piotting class frequency log values by cumulative frequency.

7). Note where break in slope of graph occurs.

For those cases where the data were sparce and the values were clustered near the lower detection limit of the instrument, with a few high values at the opposite extreme, a more empirical method was used. This method called for arranging the data in ascending numerical order then inspecting the data for any gaps. The anomalous values are differentiated from background values... For the lack of a proper sampling design and computer facilities, the gap between background and the anomaly was chosen subjectively, rather than using a statistical test as recommended by Miesh (1976). When background was determined in this manner, sometimes the anomaly criteria of four times typical background was used to see how it compared with the anomalous results of the ranking method.

As a further aid in determining background mercury values, sample localities were chosen within a mile or two of the study area. Care was taken to try to sample on the same parent material as in the study area. It was assumed that there were no extreme regional trends.

SOIL MERCURY SURVEYS HOT SULPHUR SPRINGS AREA

Introduction

As part of the resource assessment program of the Hot Sulphur Springs area, 118 soil samples were collected and analyzed for mercury from two areas (Fig. 7). In first area samples were collected along four lines across the Mount Bross Fault. The second region encompassed a large geographic area south and west of Hot Sulphur Springs. Unlike some other areas in Colorado where this method was employed, the method proved less than satisfactory in helping to delineate the geological conditions controling the occurrence of the Hot Sulphur Springs thermal waters.

\section{Soil Description}

On the hillside in back of the Hot Springs Motel, the soil appears to have formed from the Middle Park Formation. The B horizon, from which samples were taken, is light brown, unconsolidated, and sandy to clayey. The regetation consists of a sparse cover of grasses and sage, on a slope averaging $15^{\circ}$. In the southern part of the study area where most of the faulting occurred, the soil appeared to have formed from the bed rock of the Dakota and Morrison Formations and the Precambrian granitics. The B horizon in this locataion has more variation in lithology, organic and clay matter. The vegetation is thicker, with lodge pole pine, juniper, scrub oak and aspen.

\section{Mercury Surveys}

The distribution of the analytical data does not lend itself to statistical methods for background and anomalous determinations. While analytical values ranged up to $358 \mathrm{ppb}, 92 \%$ of the values are less than $21 \mathrm{ppb}$ (Table 2 and Fig. 8 ). It is not possible to accurately determine what the background value are for the low values are near the detection limit of the instrument. Thus, it is quite probably that typical values could range as high as $20 \mathrm{ppb}$. 


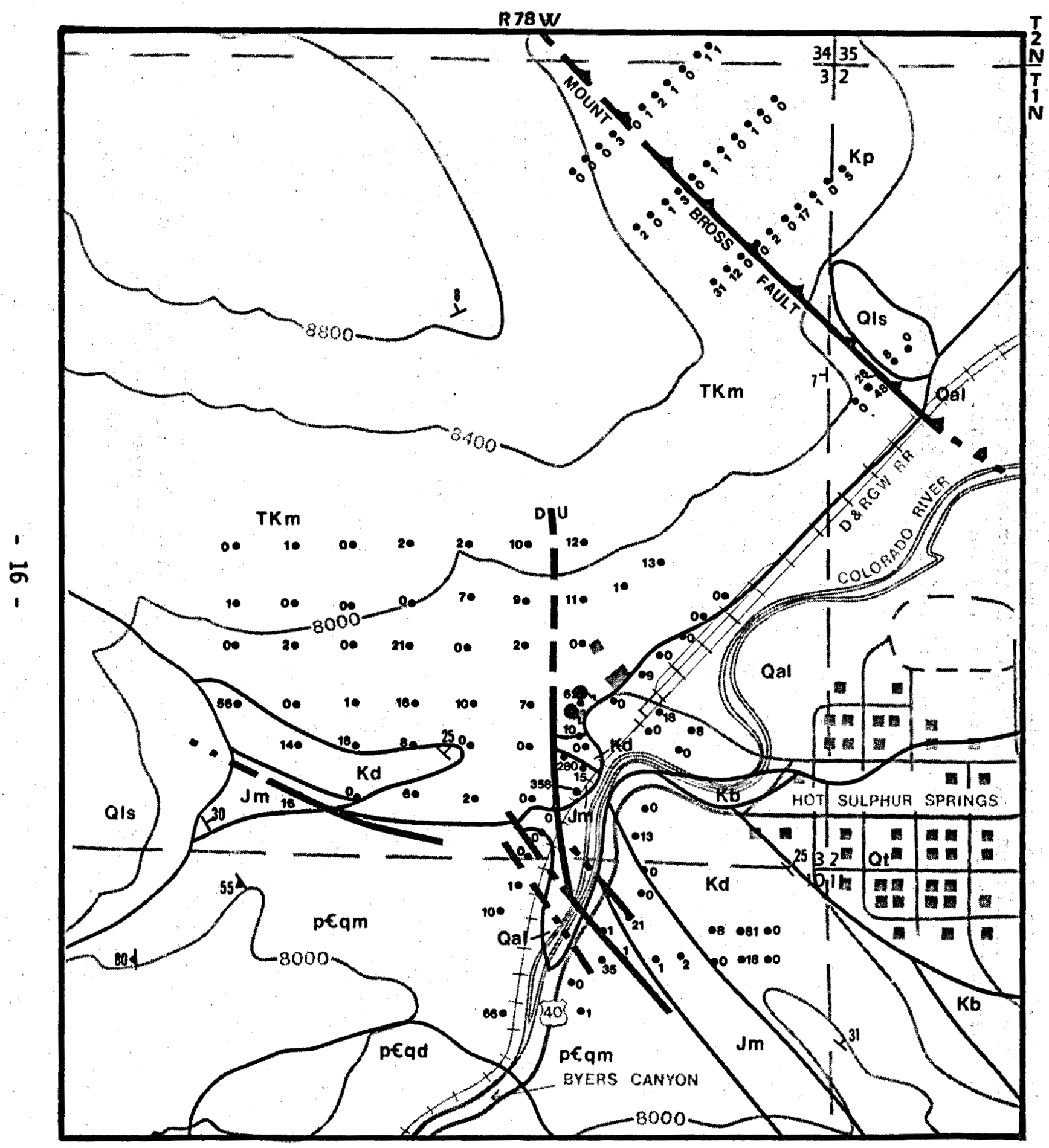

-1 Sampling locality with sample analysis in ppb of mercury

a Hot spring

See Figure 2 for geology explanation.

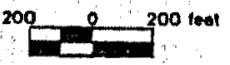

Base modified from U.S.G.S.

$7 \frac{1}{2}$ ' topographic quadrangle map.

Figure 7. Location of soil mercury sample sites, Hot Sulphur Springs area. 
To determine background values, 37 soil samples were collected approximately $5 \mathrm{mi}(8 \mathrm{~km})$ from the study area across the Mount Bross Fault. Analytical values ranged from a low of $0 \mathrm{ppb}$ to a high of $48 \mathrm{ppb}$ with a median value of of 6 ppb mercury. With one exception there was no noticeable difference in the analytical data across the Mount Bross Fault. Thus, it is concluded that anomalous mercury values in the Hot Sulphur Springs area are above 40 to $50 \mathrm{ppb}$; based on subjective judgement as to where a break in the ranked data occurs.

Aside from the high mercury value found "in" the hot springs or in the immediate vicinity of the springs, there are only two or three values (Fig. 7 ) that might be considered anomalous. The values don' $t$ indicate any pattern and appear to be well away from any structure.

Table 2 Analytical mercury data* arranged in ascending rank. See Fig. 6 for location of sample points.

$\begin{array}{rlllllllr}0 & 0 & 0 & 0 & 1 & 2 & 8 & 15 & 56 \\ 0 & 0 & 0 & 0 & 1 & 2 & 8 & 16 & 62 \\ 0 & 0 & 0 & 0 & 1 & 2 & 8 & 16 & 66 \\ 0 & 0 & 0 & 0 & 1 & 2 & 9 & 16 & 81 \\ 0 & 0 & 0 & 0 & 1 & 2 & 10 & 17 & 280 \\ 0 & 0 & 0 & 0 & 1 & 3 & 10 & 18 & 358 \\ 0 & 0 & 0 & 0 & 1 & 3 & 10 & 18 & \\ 0 & 0 & 0 & 1 & 1 & 5 & 10 & 18 & \\ 0 & 0 & 0 & 1 & 1 & 6 & 11 & 21 & \\ 0 & 0 & 0 & 1 & 2 & 6 & 12 & 21 & \\ 0 & 0 & 0 & 1 & 2 & 7 & 12 & 28 & \\ 0 & 0 & 0 & 1 & 2 & 7 & 13 & 31 & \\ 0 & 0 & 0 & 1 & 2 & 8 & 13 & 35 & \\ 0 & 0 & 0 & 1 & 2 & 8 & 14 & 48 & \end{array}$

*Represents just one of the values at a sample locality.

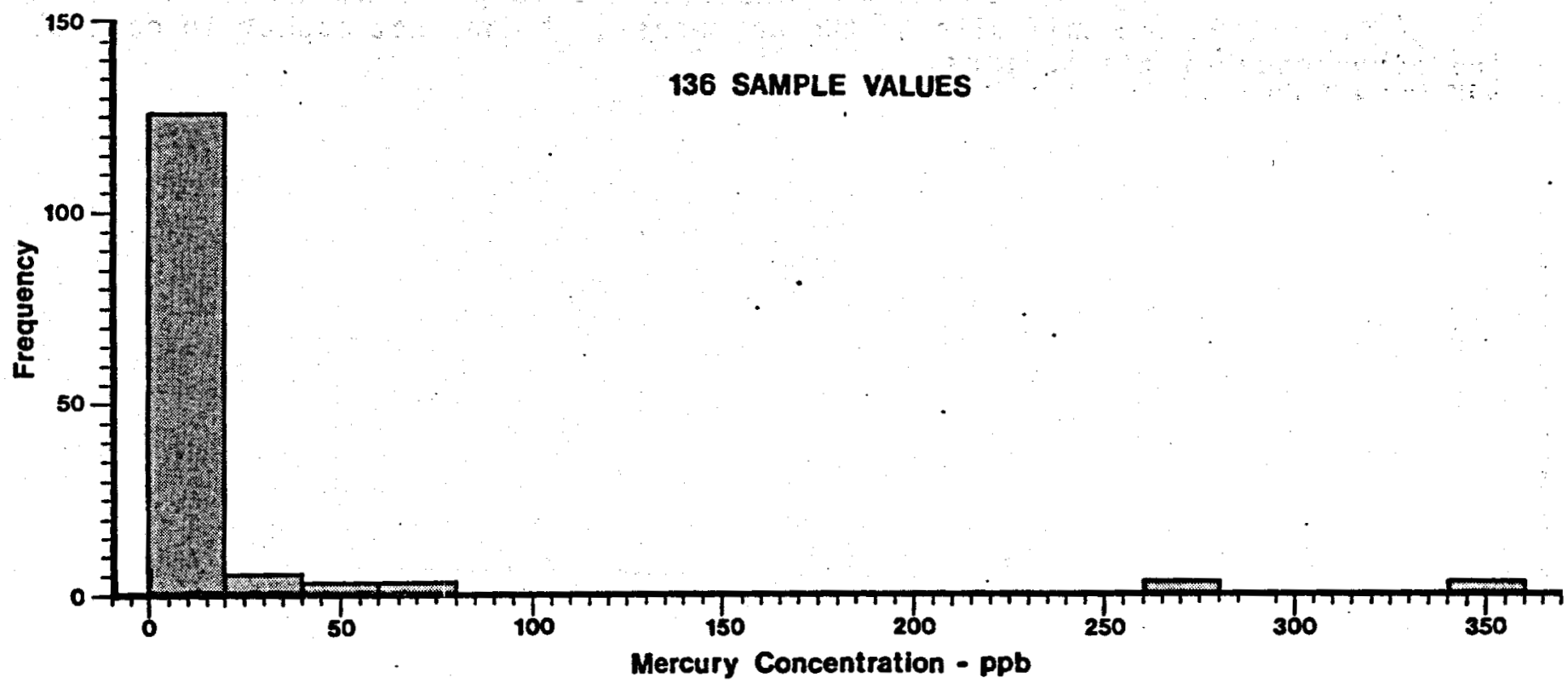

Figure 8. Soil mercury analytical frequency distribution. 


\section{Introduction}

Prior to this investigation no geophysical surveys had been conducted in and adjacent to the Hot Sulphur Springs geothermal area. As part of the assessment program dipole-dipole electrical resistivity measurements were made along six lines totaling $9,300 \mathrm{ft}(2.83 \mathrm{Km}$ ) (Fig. 9) with a Scintrex RAC-8 electrical resistivity system. These measurements were made to detect areas of low resistivity. Areas of low resistivity, indicators of thermal reservoirs, are normally due to water saturation, higher than normal temperatures and a high clay matrix zone caused by faults. Due to combination of geological conditions plus equipment limitations it was not possible to acquire resistivity measurements below a depth of approximately $500 \mathrm{ft}(152 \mathrm{~m})$. A complete description of the various factors which might possibly affect electrical resistivity measurements is presented in Appendix $C$ and $a$ description of the equipment used is presented in Appendix $D$ at the end of the paper.

One of the more common methods of portraying and interperating electrical resistivity data is through the use of pseudosections which are cross sections showing the resistivity values measured along each line. In their interpretation one must be aware that resistivity values obtained along the line of the traverse may be influenced by lateral variations in the subsurface geological conditions. Figures 10 to 15 are pseudosections drawn al ong the six traverse lines. An interperation of the geological conditions being measured by the resistivity data is presented on each figure.

\section{Conclusions}

Due to steep hillsides, canyon walls, the river, railroad, and homes dipole-dipole resistivity surveys were restricted in areal extent. From the low resistive zones delineated it is believed that the extent thermal system was outlined. Several areas of low resistivity appear to be associated with the north trending fault zone west of the hot springs. This suggests that the fault zone is saturated with thermal water and may well be the conduit along which the waters are moving up from depth. Al though the large Mount Bross Fault, is located less than one half mile to the northeast, it does not appear to control the occurrence of the springs. 


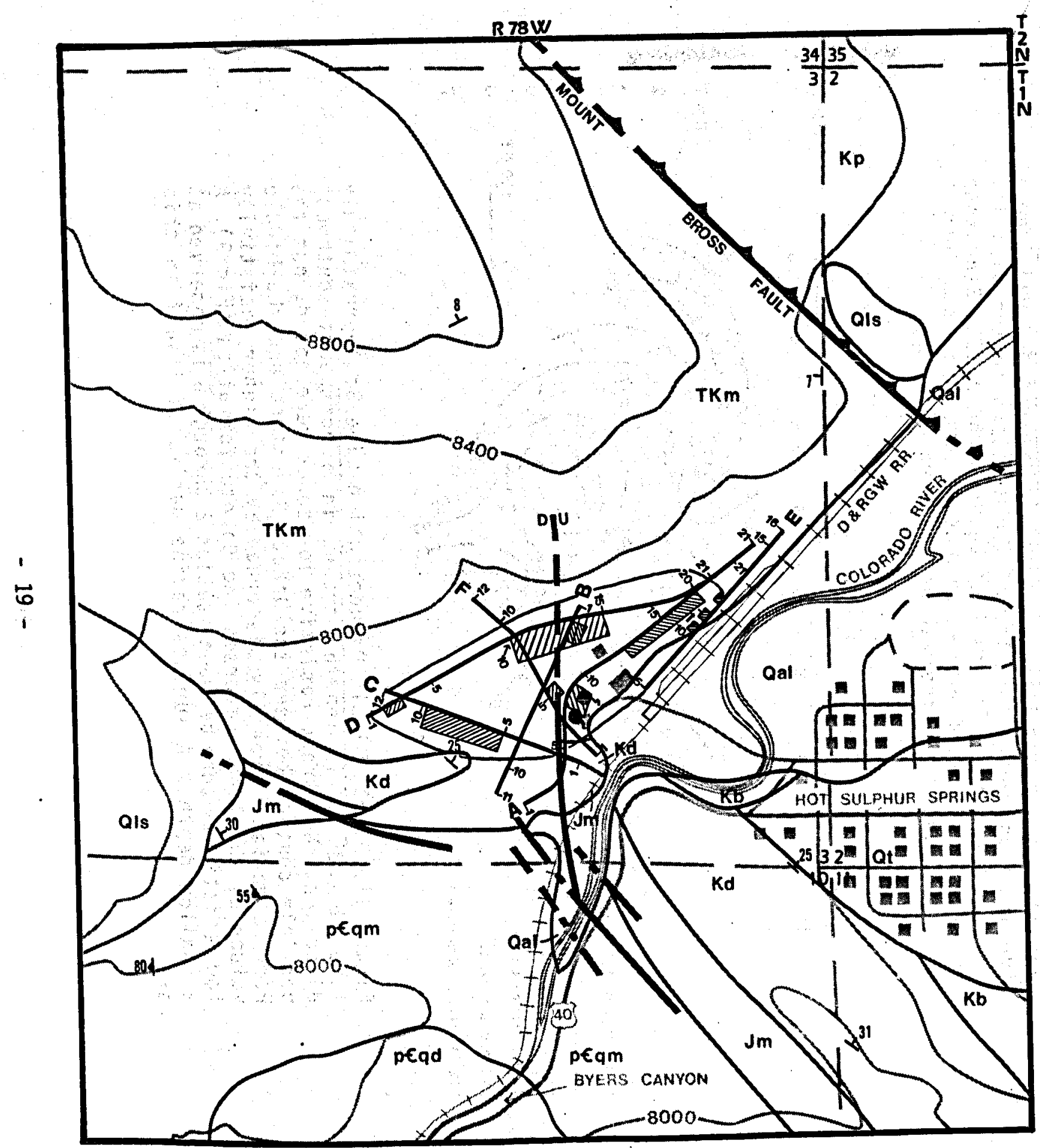

EXPLANATION

$\stackrel{s}{S}$ Resistivity line and station number

Hachered area indicates low resistivity zones

Area of low resistivity

a. Hot spring

See Figure 2 for geology explanation.
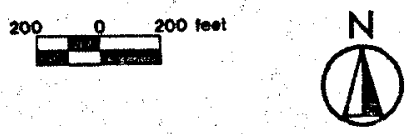

Base modified from U.S.G.S.

$7 \frac{1}{2}$ ' topographic quadrangle map.

Figure 9. Hot Sulphur Springs geophysical resistivity lines. 
$\begin{array}{llllllllllllllllllllll}5 W & 2 & 3 & 4 & 5 & 6 & 7 & 8 & 9 & 10 & 11 & 12 & 13 & 14 & 15 & 16 & 17 & 18 & 19 & 20 & 21\end{array}$

LENGTH: $2100 \mathrm{tt}(640 \mathrm{~m})$

SEPARATION: $n$ Value

DATE: July 8, 1981

TYPE: Dipole - Dipolo

SPREAD: $a=100 \mathrm{ft}$

RESISTIVITY: In okm moters

\% Hot Spring

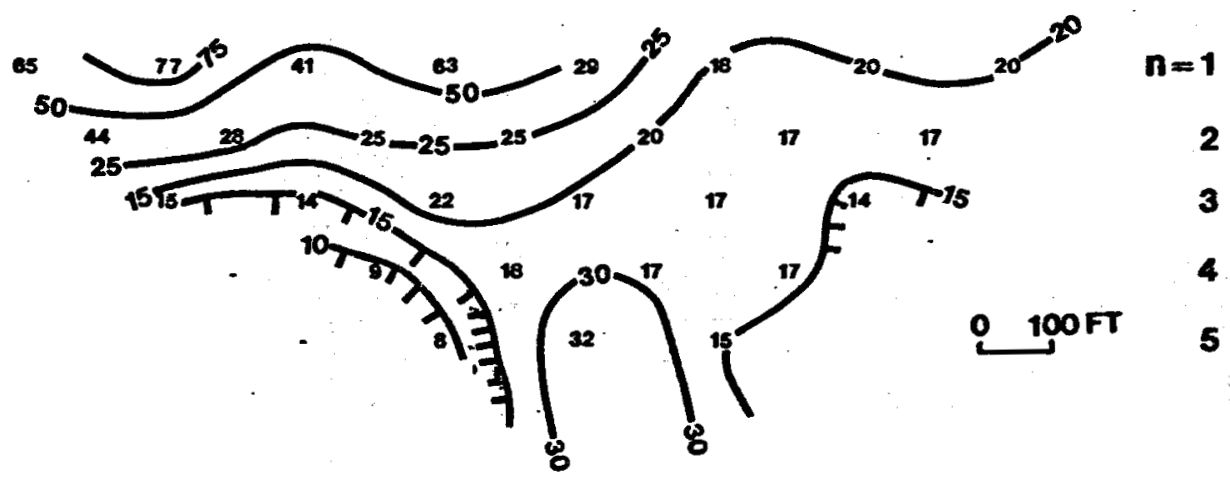

Figure 10. Dipole-Dipole Pseudosection Line A: Along this northeast- southwest line resistivities values dropped from a high of $77 \mathrm{ohm}$ meter to a low of $7 \mathrm{ohm}$ meters in the vicinity of the hot springs. The contact between the Dakota Sandstone and the Middle Park Formation was detected at stations 6 through 10 where the thermal waters were emerging.

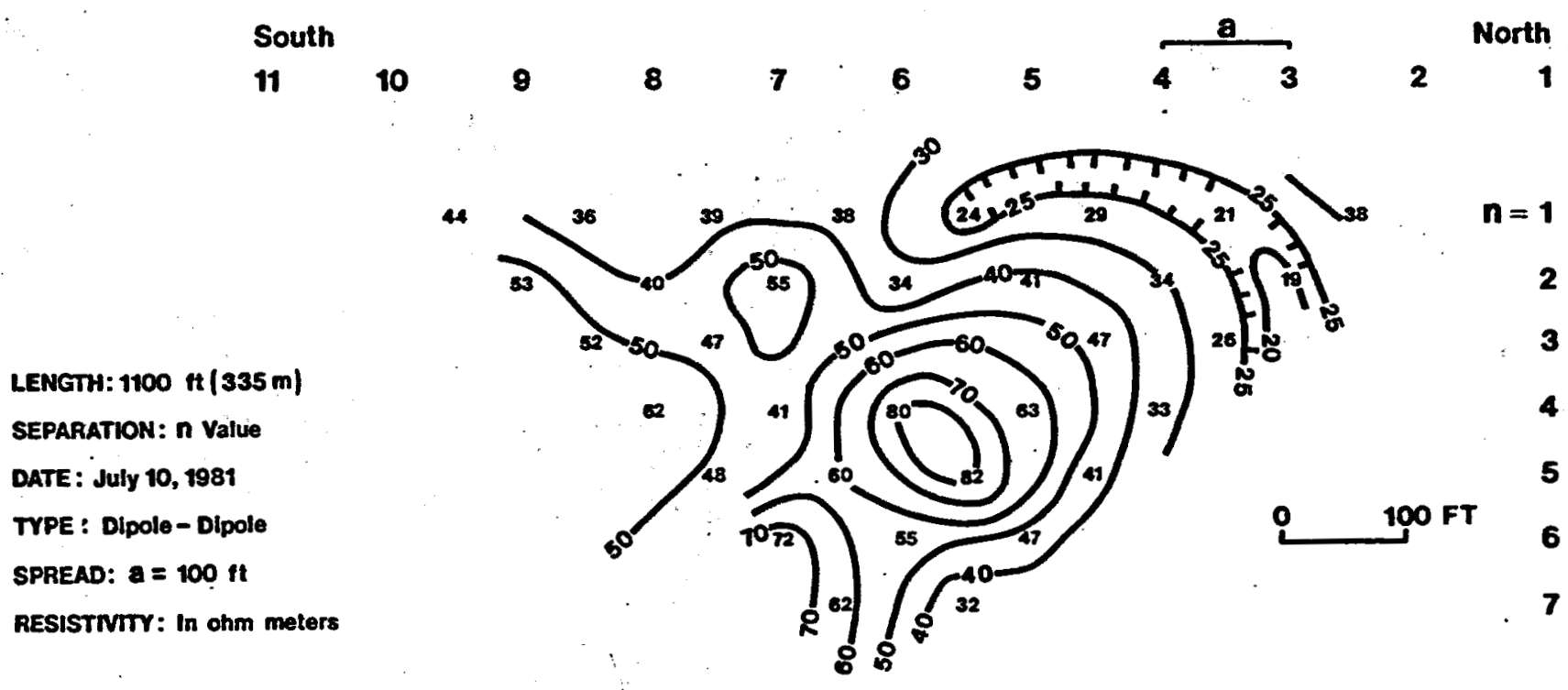

Figure 11. Dipole-Dipole Pseudosection Line B: Approximately $1100 \mathrm{ft}(335 \mathrm{~m})$ in length, trends in a northeast-southwest direction. No strong resistive low zones were noted, but the possible contact between the Dakota Sandstone and the Middle Park Formation is readily discerned by the higher resistivity values as the line traverses the Dakota formation (Fig 9). A 10w resistivity zone between station 2 through 6 is observed at a shallow depth. A surface ravine manifests itself in this area. 
West

$11 \quad 10 \quad 9 \quad 7 \quad 6$

65

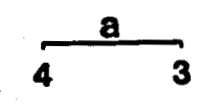

East

12

11

LENGTH: $1200 \mathrm{ft}(366 \mathrm{~m})$

41

SEPARATION: $n$ Value

DATE : July 13, 1981

TYPE : Dipole - Dipole

SPREAD: $A=100 \mathrm{ft}$

RESISTIVITY : In ohm meters

- Possible Fault

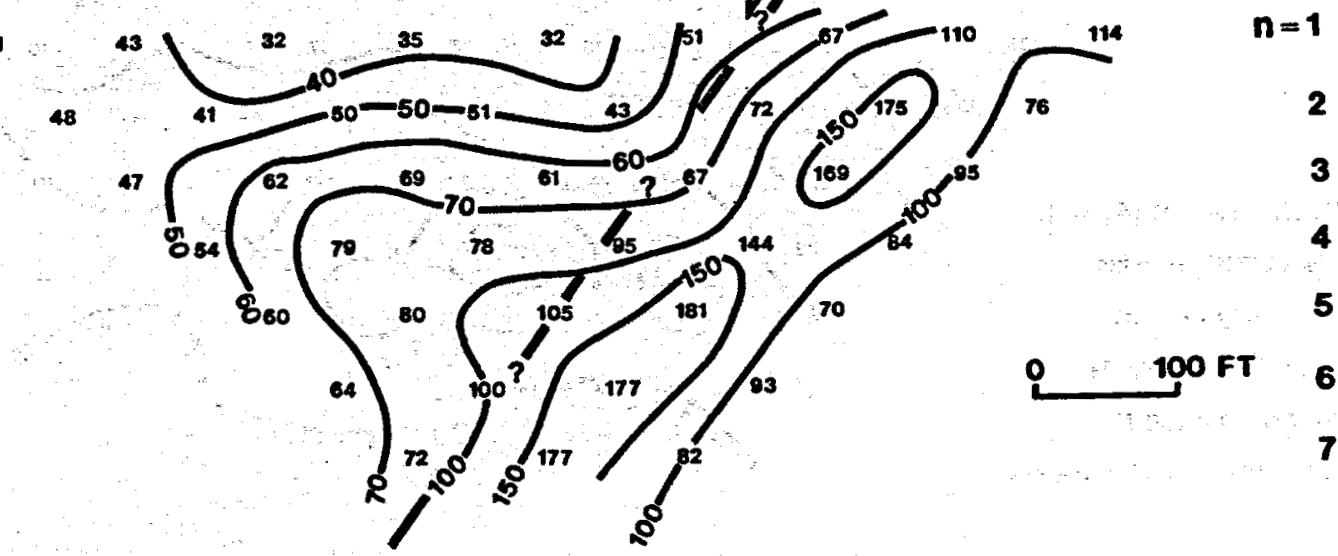

Figure 12. Dipole-Dipole Pseudosection Line C: A low resistivity zone was mapped between stations 5 and 8 . A mapped fault is depicted on the section between stations 4 and 6 down thrown to the west. It is postulated that the mapped contact between the Dakota sandstone and the Middle Park Formation may be a fault contact as it occurs in the same area where there is a distinct change in resistivity.

LENGTH: $2000 \mathrm{tt}(610 \mathrm{~m})$ SEPARATION: $n$ Value DATE : July 14, 1981 TYPE: DIpole - Dipole SPREAD: $Q=200 \mathrm{ft}$ RESISTIVITY : In ohm meters

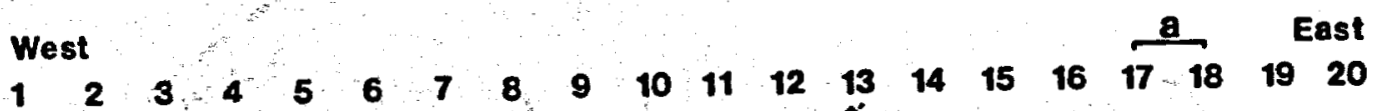
- Possible Fault
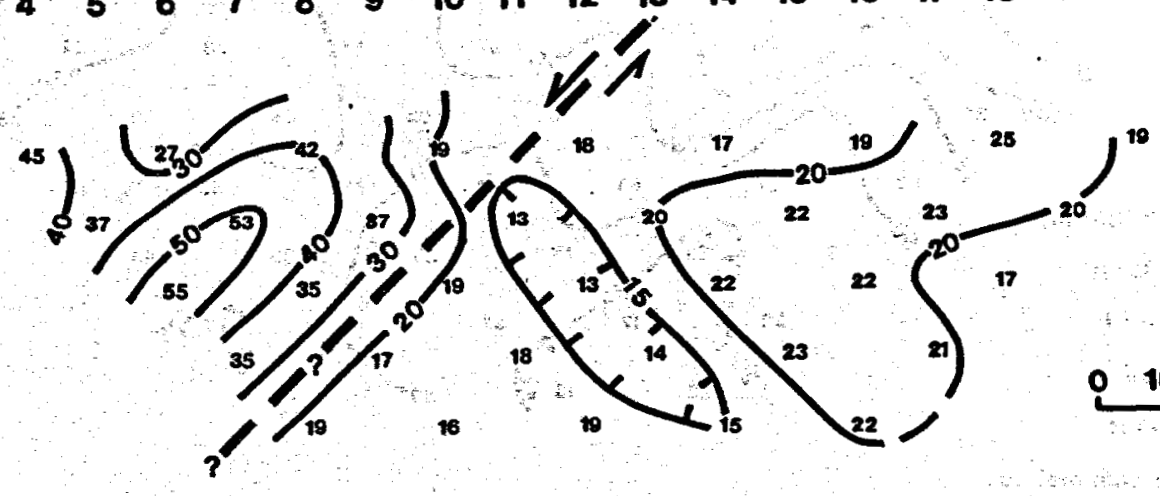

$n=1$
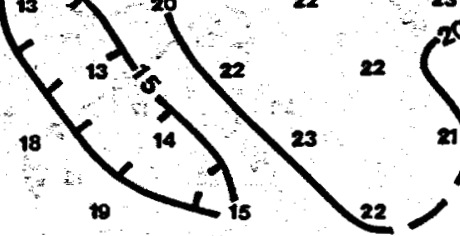

a)

- $100 \mathrm{FT}$

Figure 13. Dipole-Dipole Pseudosection Line D: This east-west 1 ine al so demonstrates a very distinct resistivity low between stations 8 through 13 . It is believed that this zone reflects varying resistivity values on either side of the mapped faut the line crossed. 
sw

LENGTH: $1600 \mathrm{ft}$ (488 m) SEPARATION: $n$ Value

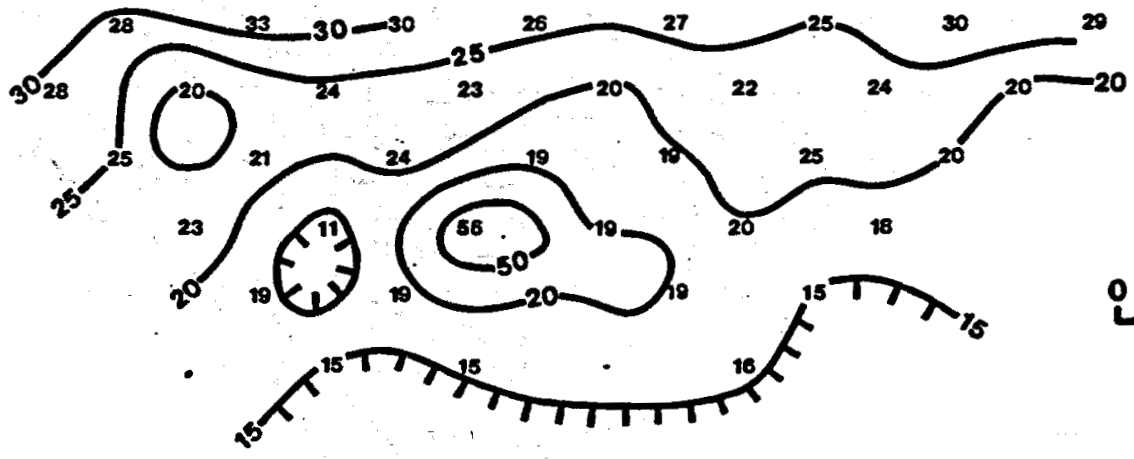

DATE : July 15, 1981

TYPE : Dipole- Dipole

SPAEAD: $a=100 \mathrm{ft}$

RESISTIVITY: in ohm meters

Figure 14. Dipole-Dipole Psuedosection Line E: No data were obtained from station 1 through 5 because of culture. A deep seated resistivity low exists the entire length of the line, however, structurally no features are apparent. This low zone may be due to the water saturated alluvium that underlay the line.

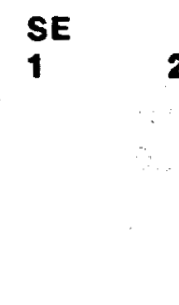

LENGTH: $1200 \mathrm{ft}$ (366 m)

SEPARATION: $n$ Valve

DATE : July.16, 1981

TYPE: Dipole - Dipole

$$
2
$$

3

5366

$\frac{a}{10 \quad 11} \quad N W$

SPREAD: $a=100 \mathrm{it}$

RESISTNITY : In ohm moters

Hot Spring

Figure 15. Dipole-Dipole Pseudosection Line F: Along this northwest- southwest trending line a deep seated low exists between stations 5 and 6 where the values decrease to 13 ohm-meter. This is probably due to the travertine deposits associated with the spring. Al so the contact between the Dakota Sandstone and the Middle Park Formation is indicated at this area. 
With the exception of this assessment program no other geological, geophysical or hydrogeological information pertaining to the thermal conditions of the area is available from which a meaningful interperation of the thermal conditions can be made. However, based on hydrogeological and geothermal conditions el sewhere, a working model of this system can be developed. This model will have await further exploration efforts to determine its accuracy.

Based on world wide occurrences, it has been determined that thermal waters are of three origins: meteoric, magmatic or a combination of the two. Meteroric waters are normal groundwaters which originated as precipitation falling on the surface of the land, some of which flowed downward along faults and fractures to a great depth where they became heated. The actual process by which these waters became heated is not known but is probably due to high heat-flow. Buelow (1980) and Decker and others (1981) have suggested that the heat flow of the Middle Park area may be higher than norma1. Another possible heating mechanism could be heat given off by the disintegration of radioactive minerals. Wells $(1960)$ showed that the concentration levels of radioactive minerals in the Tertiary age rocks of the Front Range are 15 to 25 times greater than that for average granitic rocks. No values are available on the radioactive mineral concentration levels for the granitic rocks in the Hot Sulphur Springs, but this could be a possible heat source.

Magmatic waters are those given off during the late cooling stages of a deep seated igneous rock body, like a batholith. Based on published geological information, no evidence has been given for the presence of such a feature in the Hot Sulphur Springs area. Therefore this origin is not considered a viable alternative.

Based on all available evidence the authors believe that the Hot Sulphur springs thermal waters represent deep circulation of meteoric waters along numerous faults and fractures in an area of above normal heat flow. Recharge to the system probabiy occurs on the high ground to the east.

Due to the thick sequence of insulating Pierre shale found just to the east and south of the study area, it is not possible to make any accurate predictions on required circulation depths. Decker and others (1981) noted note that the high heat-flow values, late Cenozoic igneous activity and numerous hot springs all provide most compelling evidence that low to moderate temperature resources could exist at shallow depths in northwest colorado. They noted that in areas where thick sequences of shale exist that low-to moderate-temperature waters $\left(70-100^{\circ} \mathrm{C}\left(158^{\circ} \mathrm{F}-212^{\circ} \mathrm{F}\right)\right)$ could be found at their base. 
The geothermal resources of the Hot Sulphur Springs area are restricted to a small area on the north side of the Colorado River in the community of Hot Sulphur Springs. In this area there are approximately 10 springs having a maximum temperature of $111^{\circ} \mathrm{F}\left(44^{\circ} \mathrm{C}\right)$, and a combined discharge of approximately $50 \mathrm{gpm}$. The waters are a sodium bicarbonate type.

As determined by geology and reconfirmed by geophysical surveys, the springs are associated with a small northeast trending fault. No evidence was gathered that would determine if they were or were not associated with the major Mount Bross fault located to the northeast.

While no data was collected to prove or disprove it, it is the authors belief that the thermal waters are normal meteoric ground waters that became heated due to deep circulation in an area of above normal heat flow. Pearl (1979) estimated that the areal extent of the Hot Sulphur Springs geothermal sys tem could encompass approximately $1.35 \mathrm{sq} \mathrm{mi}(0.91 \mathrm{sq} \mathrm{Km})$ and could contain $0.0698^{\prime} Q^{\prime} s$ of heat energy at a temperature of $104^{\circ} \mathrm{F}\left(40^{\circ} \mathrm{C}\right)$. Pearl $(1979)$ estimated that this system was bounded by the Mount Bross fault on the north. Evidence gathered during the course of this investigation did not support this conclusion. Therefore; it is here estimated that the Hot Sulphur Springs geothermal area does not encompass more than $1 \mathrm{sq} \mathrm{mi}(2.59 \mathrm{sq} \mathrm{Km})$ and is primarily restricted to an area bounded on the west by the north trending fault. Due to the presence of a favorable impermeable, insulating caprock in the form of the Pierre shale, it is not possible to estimate depth of circulation. The presence of this caprock means that thermal waters may al so be found at relatively shallow depths $(<5,000 \mathrm{ft}[1.52 \mathrm{~km})]$ east of Hot Sulphur Springs. Decker and others (1981) belived that moderate to high temperature waters, adequate for the generation of electricity, could exist in some parts of North and Middle Parks if an adequate impermeable caprock exists. They noted that the most likely area for this occurrence would be in the Basalt Mountain-Flat Top-State Bridge area, southwest of the Hot Sulphur Springs area. 
Anderson, D.N. and Lund, J.W., eds, 1979, Direct utilization of geothermal energy: A Technical Handbook: Geothermal Resources Council Spec. Rept. No. 7 ,

Barrett, J. K., and Pearl, R. H., 1976, Hydrogeologic data of thermal springs and wells in Colorado: Colorado Geol. Survey Info. Series $6,124 \mathrm{p}$.

1978, An appraisal of Colorado's geothermal resources: Colorado Geo1. Survey Bu11. 39, 229 p.

Berry, G.W., Grim, P.J., and Ikelman, J.A., 1980, Thermal spring list for the United States: National Geoph. and Solar-Terrestrial Data Center, National Oceanic and Atmospheric Adm., Boulder, CO., 59 p.

Buelow, K.L., 1980, Geothermal studies in Wyoming and northern Colorado, with a geophysical model of the southern Rocky Mountains near the Colorado-Wyoming boarder: Dept. of Geology, Univ. of Wyoming, unpub. M.S. thesis, $150 \mathrm{p}$.

Capuano, R.M. and Bamford, R.W., 1978, Initial investigation of soil mercury geochemistry as an aid to drill site selection in geothermal systems: Earth Science Laboratory, Univ. of Utah Research Insntitute, ESL-13, Salt Lake City, Utah.

Coe, B.A., 1978, Geothermal energy development in Colorado: Processes, Promises and Problems: Colo. Geol. Survey Info. Series 9, 52 p.

1982, Industrial market opportunities for geothermal energy in Colorado: Colorádo Geol. Survey Spec. Pub. 20, $66 \mathrm{p}$.

Combs, Jim, 1980, Geothermal exploration strategy and techniques: Geothermal Services Inc., San Diego, CA, 41 p.

Cox, M. E., and Cuff, K. G., 1980, Rn and Hg Surveys: Geotherma1 exploration in N.E. Maui Hawati, in Geothermal Energy for the Eighties, Transactions Geothermal Resources Council Annual Meeting, Salt Lake City, UT: Geothermal Res. Counci1, Davis, CA, P. 451-454.

Decker, E. R., Buelow, K. L., and Heasler, Henry, 1981, Heat flow, radioactivity, gravity, and geothermal resources in northern Colorado and southern wyoming: Dept. of Geology, Univ. of Wyoming, Unpub. report, to U.S. Dept. of Energy/Div. of Geothermal Energy, 26 p.

George, R. D., Curtis, H. A., Lester, O. C., Crook, J. K., and Yeo, J.M., 1920, Mineral Waters of Colorado: Colorado Geol. Survey Bu11. 11, 474p

Izett, G.A., 1968, Geology of the Hot Sulphur Springs quadrangle, Grand County, Colorado: U.S. Geol. Survey Prof. Paper 586, 79 p. 
1975, Late Cenozoic sedimentation and deformation in northern Colorado and adjoining areas, in Curtis, B.F., Cenozoic History of the Southern Rocky Mountains: Geol. Soc. America Memoir 144, pp. 179-209.

Izett, G.A., and Hoover, D.L., 1963, Preliminary geologic map of the Hot Sulphur Springs SE quadrangle, Grand County, Colorado: U.S. Geol. Survey Mineral Invest. Field Studies Map MF-271, Scale 1:24,000

Klusman, R.W. and Landress, R.A., 1979, Mercury in soils of the Long Valley, California, geothermal system: Jour. Volcanology, and Geothermal Res., v. 5, pp. 49-65.

Klusman, R.W., Cowling, S., Culvey, B., Roberts, C., and Schwab, A.P., 1977, Preliminary evaluation of secondary controls on mercury in soils of geothermal districts: Geothermics, v. 6, pp. 1-8.

Kruger, Paul, and 0tte, Carel, eds., 1973, Geothermal energy--resources, production, stimulation: Stanford Univ. Press, $360 \mathrm{p}$.

Lepeltier, Clande, 1969, A simplified statistical treatment of geochemical data by graphical representation: Econ. Geology, v. 64, pp. 538-550.

Levinson, A.A., 1974, Introduction to exploration geochemistry: Applied Publishing Ltd., Calgary, pp. 561-568.

Lewis, E.L., 1966, The thermal springs of Colorado--A resource appraisal: Univ. of Colorado Dept. Geography, Master Sci. Thesis, 91 p.

Mallory, E.C., Jr. and Barnett, P.R., 1973, Chemistry and spectrochemical analysis of selected groundwaters in Colorado: U.S. Geol. Survey open-file Report, $47 \mathrm{p}$.

Matlick, J.S. III and Buseck, P.R., 1976, Exploration for geothermal areas using mercury - a new geochemical technique, in Proceedings Second United Nations Symposium on the Development and Use of Geothermal Resources, San Francisco, CA.: U.S. Gov. Printing Office, v. 1, pp. 785-792.

Miesh, A.T., 1976, Sampling designs for geochemical surveys - syllabus for a short course: U.S. Geol. Surv. Open-file Report 76-772.

Muffler, L.J.P., ed., 1979, Assessment of geothermal resources of the United States--1978: U.S. Geol. Survey Circular 790, 163 p.

Peale, A. C., 1886, Lists and analyses of the mineral springs of the United States: U.S. Geol. Survey Bull. 32, 235 p.

Pearl, R.H., 1972, Geothermal resources of Colorado: Colorado Geol. Survey Spec. Pub. 2, 54 p.

R. H., 1979 , Colorado's hydrothermal resource base - An assessment: Colorado Geol. Survey Resource Series 6, 144 .

Scintrex, 1971, RAC-8 low frequency A.C. resistivity system operation manua 1: Concord, Ontario, Canada, $22 \mathrm{p}$. 
Soil Test Inc., 1968, Earth resistivity manual: Evanston, I1linois, 52 p.

Steven, T.A., 1975, Middle Tertiary volcanic fields in the southern Rocky Mountains, in Curtis, B.F. (ed), Cenozoic History of the Southern Rocky Mountains: Geol. Soc. America Memoir 144, pp. 75-94.

Sumner, J. S., 1976, Principles of induced polarization for geophysical exploration: El sevier Scientific Publishing Company, pp. 1-277.

Tweto, Ogden, 1975, Laramide (Late Cretaceous-Early Tertiary) Orogeny in the Southern Rocky Mountains, in Curtis, B.F. (ed), Cenozoic History of the Southern Rocky Mountains: Geol. Soc. America Memoir 144, pp. 1-44.

Waring, G. A., 1965, Thermal springs of the United States, and other countries of the world--A summary, revised by R.F. BI ankenship and Ray Bental1: U.S. Geo1 Survey Prof. Paper 492, 383 p.

Wells, J.D., 1960, Petrography of radioactive Tertiary igneous rocks, Front Range Mineral Belt, Colorado: U.S. Geo1. Survey Bu11. 1032-E, Pp. $11-21$.

White, D.E., 1967, Mercury and base-metal deposits with associated thermal and mineral waters, in Barnes, H.L. ed., Geochemistry of hydrothermal ore deposits: New York, Holt, Rinehart and Winston, PP. 575-631.

White, D.E., Hinkle, L.G., and Barnes, I., 1970, Mercury content of natural thermal and mineral fluids: U.S. Geol. Survey Prop. Paper 713, pp 25-28.

White, D.E., and Williams, D.L., eds., 1975, Assessment of geothermal resources of the United States--1975: U.S. Geol. Survey Circular $726,155 \mathrm{p}$.

Zacharakis, T.G., 1981, Revised heat flow map of Colorado: Colorado Geol. Survey Map Series 18, scale 1:1,000,000. 


\section{APPENDIX A}

\section{GEOTHERMAL ENERGY AND ITS POSSIBLE USES}

Geothermal energy, the heat generated by natural processes beneath the earth's surface, normaliy occurs at great depths. In some places, however it can be found close to or at the surface in the form of volcanoes, geysers or hot springs. Where it occurs near the surface it can be developed and put to beneficial use. Geothermal energy in the form of hot springs has been used by mankind for medicinal and cooking purposes since the earliest days of recorded history. In the last 100 years devel opment of this energy source for other uses has occurred, and it is now used for such purposes as: Generation of electricity; heating and cooling of buildings; processing of food and other goods; heating cattle barns, greenhouses and fish ponds; milk pasteurization; and recreation and medicinal. Due to declining petroleum reserves it is anticipated that in years to come development of this energy source will increase. Figure 15 lists some of the uses geothermal energy could be put to and the temperatures required.

Coe (1978 and 1982) has presented a discussion on the possible uses, of geothermal energy development in Colorado and some of the problems associated with its development. If the reader is interested in learing more about geothermal enery and its possible development he/she is referred to papers by: Anderson and Lund (1979); Kruger and Otte (1973); Muffler (1979); and White and Williams (1975). Listed on the back cover is a complete listing of all papers and reports published by the Colorado Geological Survey relating to the geothermal resources of Colorado. 


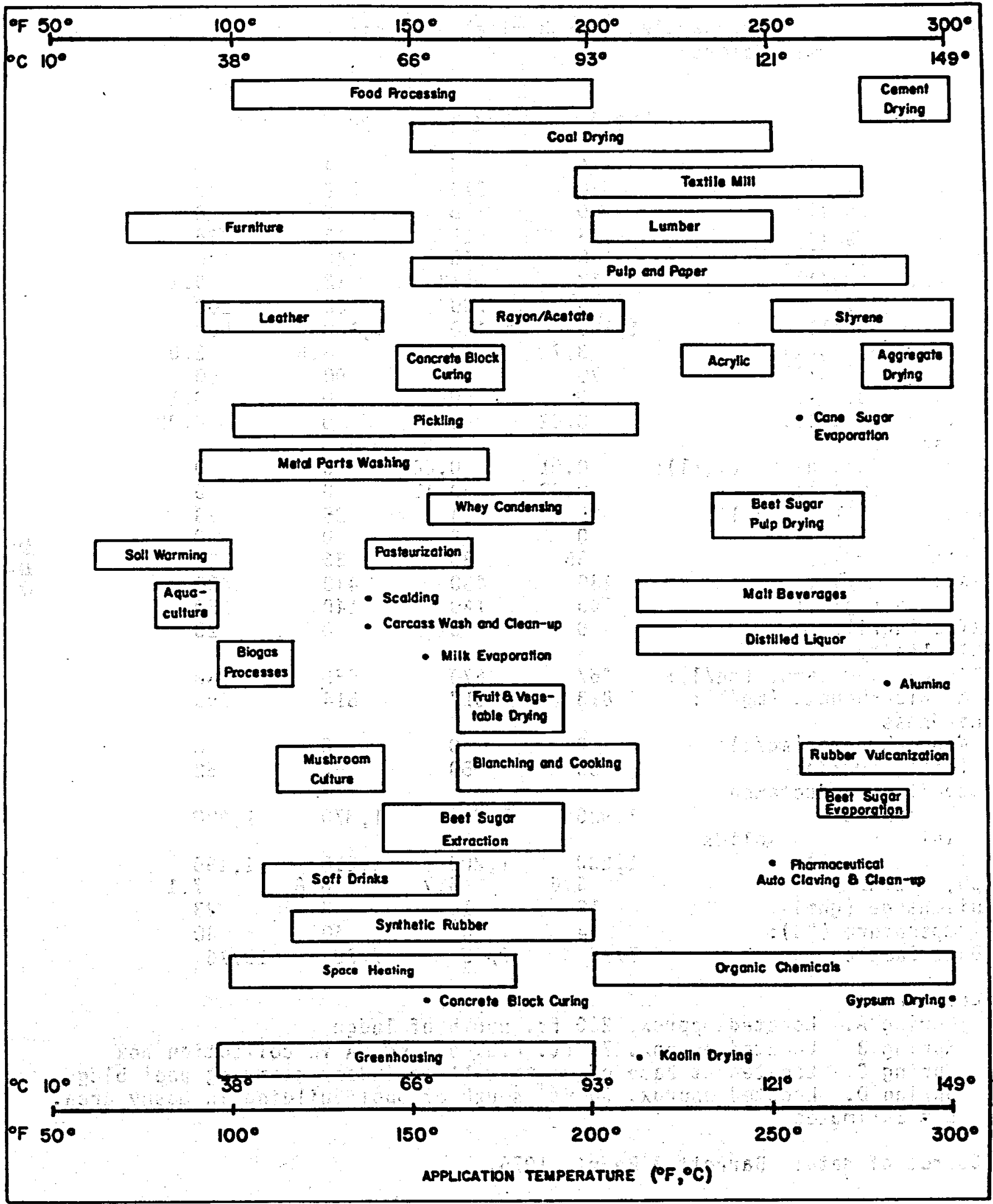

Figure 16. Temperature range for some direct uses of geothermal energy. (Adopted from Aderson and Lund, 1979, p.4-26.) 
Table 3. Physical Properties and Chemical Analysis of Hot Sulphur Springs Thermal Waters.

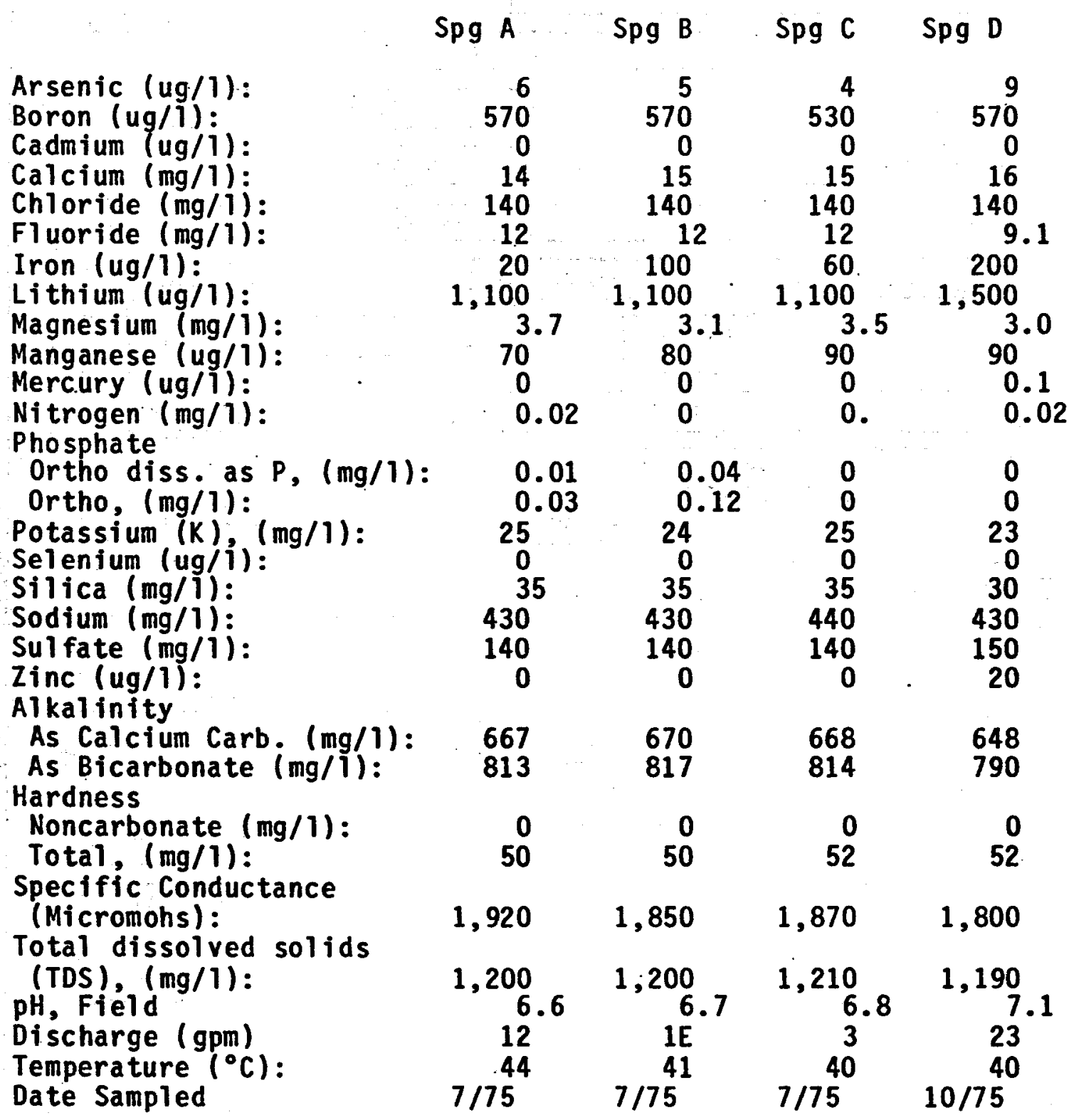

\section{Location:}

Spring A. Located approx. $250 \mathrm{ft}$. north of lodge

Spring B. Located approx. $75 \mathrm{ft}$. n.e. of Spg. A in collection box.

Spring C. Located at base of north wall on indoor swimming pool bldg. Spring D. Located approx. $50 \mathrm{ft}$. south of pool building in mashy area. $E$ = Estimated

Source of data: Barrett \& Pearl, 1976. 
TABLE 4. Trace Elements In Hot Sulphur Sprints Thermal Waters Values reported in Micrograms/liter (UG/L)

\section{Spg A Spg B}

$\begin{array}{lrr}\text { Aluminum } & 95 & 130 \\ \text { Barium } & 100 & 130 \\ \text { Beryllium } & <2 & <2 \\ \text { Bismuth } & <9 & <9 \\ \text { Chromium } & <9 & <9 \\ \text { Cobalt } & 3 & 2 \\ \text { Copper } & < & <9 \\ \text { Gallium } & <9 & <9 \\ \text { Germanium } & <9 & <9 \\ \text { Lead } & <9 & <9 \\ \text { Nickel } & <1 & <1 \\ \text { Silver } & 630 & 790 \\ \text { Strontium } & <9 & <9 \\ \text { Tin } & <5 & <5 \\ \text { Titanium } & <9 & <9 \\ \text { Vandium } & <15 & <15 \\ \text { Zirconium } & \text { P } & 9 \\ \text { Source of data: } & \text { Barrett and Pearl (1976) }\end{array}$

Table 5. Associated radioactivity, Hot Sulphur Springs thermal waters. Spring B.

Values reported in Picocuries/liter (PCi/1)

Source: Barrett and Pearl (1976)

\begin{tabular}{|c|c|c|c|}
\hline $\begin{array}{l}R n-222 \\
R a-226 \\
R a-228 \\
U-234\end{array}$ & 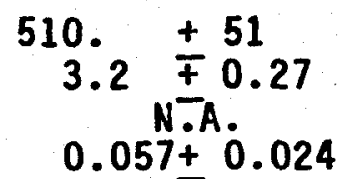 & $\begin{array}{l}U-235 \\
U-238 \\
T h-230 \\
T h-232\end{array}$ & $\begin{array}{l}<0.01 \\
0.041 \pm 0.021 \\
<0.0069 \\
<0.0085\end{array}$ \\
\hline
\end{tabular}




\section{FACTORS AFFECTING RESISTIVITY}

Electrical resistivity geophysical methods used in geothermal exploration measure the electrical resistivity of rocks at various depths. Temperature, porosity, salinity of fluids, and the content of clays will normally be higher within the geothermal reservoir than in the surrounding subsurface rocks. Consequently, the electrical resistivity in thermal reservoirs is low compared to the surrounding rock. Basically, resistivity methods utilize manmade currents which enter the subsurface via two electrodes with the resultant potential measured at two other electrodes (Soil Test Inc., 1968).

The difficulty with interpretation stems from the fact that resistivity is a complicated function of the following parameters: temperature, porosity, salinity, and clay content. For example, a low temperature, highly saline ground water can provide the identical low resistivity anomaly as a high temperature, moderatately saline geothermal system. Therefore, to be most effective, this method should be used in conjuction with direct temperature gradient measurements and other types of data that are of value in determining the reason for the resistivity values obtained (Soil Test Inc., 1968).

Zones of low resistivity in a geothermal environment can be caused by a high dissolved solid content of thermal water versus ground water, higher clay content due to the hydrothermal alteration within the fault zones, and the higher temperature of the thermal fluids. Finally, the ability of the geophysicist to isolate any of the aforementioned factors and relate it to the object of the resistivity exploration progran rests upon a combination of elimination process of constant or slowly varying factors from those that are most susceptible to change. 


\section{APPENDIX D}

\section{INSTRUMENTATION}

\section{Scintrex RAC-8 Low Frequency Resistivity System}

The following description is taken from the Scintrex Manual (1971).

The Scintrex RAC-8 electrical resistivity equipment used by the Colorado Geological Survey is a very low frequency AC resistivity system with high sensitivity over a wide measuring range. The transmitter and receiver operate independent of each other, requiring no references wires between them. This allows a great deal of efficiency and flexibility in field procedures and el iminates any possibility of interference from current leakage or capacitive coupling within the system.

The transmitter produces a $5 \mathrm{~Hz}$ square wave output at a preset electronically stabilized, constant current amplitude. The output current level is switch selectable at any one of five values ranging from 0.1 to 333 milliamps.

The receiver is a high sensitivity phase lock, synchronous detector, which locks onto the transmitter signal to make the resistivity measurement. When set at the same current setting as the transmitter, the receiver gives a direct readout of $V / I$ ratio.

The RAC-8, with a measuring range from .0001 to 10,000 ohms, high sensitivity to weight ratio gives fast accurate resistivity data. With the $10 \mathrm{w}$ AC operating frequency, good penetration may be obtained in excess of $1500 \mathrm{ft}$ under favorable conditions. The system has an output vol tage maximum of $1000 \mathrm{~V}$ peak to peak. However, the actual output voltage depends on the current level and load resistance. The output power under optimum conditions approaches 80 watts.

In areas of very low resistive 1 ithology, the penetration power was reduced by a sizeable amount. Realizing the aforementioned constraint, the intent was to delineate gross potential differences in resistivity. In some areas where the lithol ogy reflected small differences in resistivity, the RAC -8 system appeared to average the penetrated 1 ithologic sequences rather than picking up distinct breaks. Considering cost and time constraints, the system performed as indicated and performed best in areas of high resistivity. 


\section{APPENDIX E \\ RESISTIVITY FIELD PROCEDURES}

Before discussing the various electrode spreads used, it is necessary to consider what is actually measured by an array of current and potential electrodes. By measuring vol tage (V) and current (I) and knowing the electrode configuration, a resistivity $(p)$ is obtained. Over homogeneous isotropic ground this resistivity will be constant for any current and electrode arrangement. That is, if the current is maintained constant and the electrodes are moved around, the potential voltage (V) will adjust at each configuration to keep the ratio $(V / I)$ constant (Sumner, 1976).

Apparent Resistivity:

$$
\begin{aligned}
P_{a} & =2 P I a \quad V / I \quad \text { General Formula } \\
a & =\text { Spread length } \\
V / I & =V o l \text { tage current ratio } \\
P_{a} & =\text { apparent resistivity } \\
2 P I & =6.2
\end{aligned}
$$

See Figure 17 for a schematic diagram for resistivity.

One of the most widely used electrical processing techniques for geothermal resource exploration is the resistivity profiling and sounding method. The method utilizes various arrays, but the most common are the Wenner, the Schlumberger and the Dipole-Dipole schemes. The colorado Geological Survey extensively employed the latter method primarily because of the ease of use and also being able to obtain both horizontal and vertical sections.

If the ground is unhomogeneous, however, and the electrode spacing is varied, or the spacing remains fixed while the whole array is moved, then the ratio will in general change. This results in a different value of $p$ for each measurement. Obviously the magnitude is intimately involved with the arrangement of electrodes.

This measured quantity is known as the apparent resistivity, Pa. Al though it is diagnostic, to some extent, of the actual resistivity of a zone in the vicinity of the electrode array, this apparent resistivity is definitely not an average value. Only in the case of homogeneous ground is the apparent value equivalent to the actual resistivity (Sumner, 1976).

\section{Wenner Array}

In the Wenner Spread (Fig. 18) the electrodes are uniformly spaced in a line (Sumner, 1976).

In spite of the simple geometry, this arrangement is often quite inconvenient for field work and has some disadvantages from the theoretical point of view as well. For depth exploration using the Wenner Spread, the electrodes are expanded about a fixed center, increasing the spacing in steps. For lateral exploration or mapping the spacjng remajns constant and all foyr mapping, the apparent resistivity for each array position is plotted against the center of the spread. 


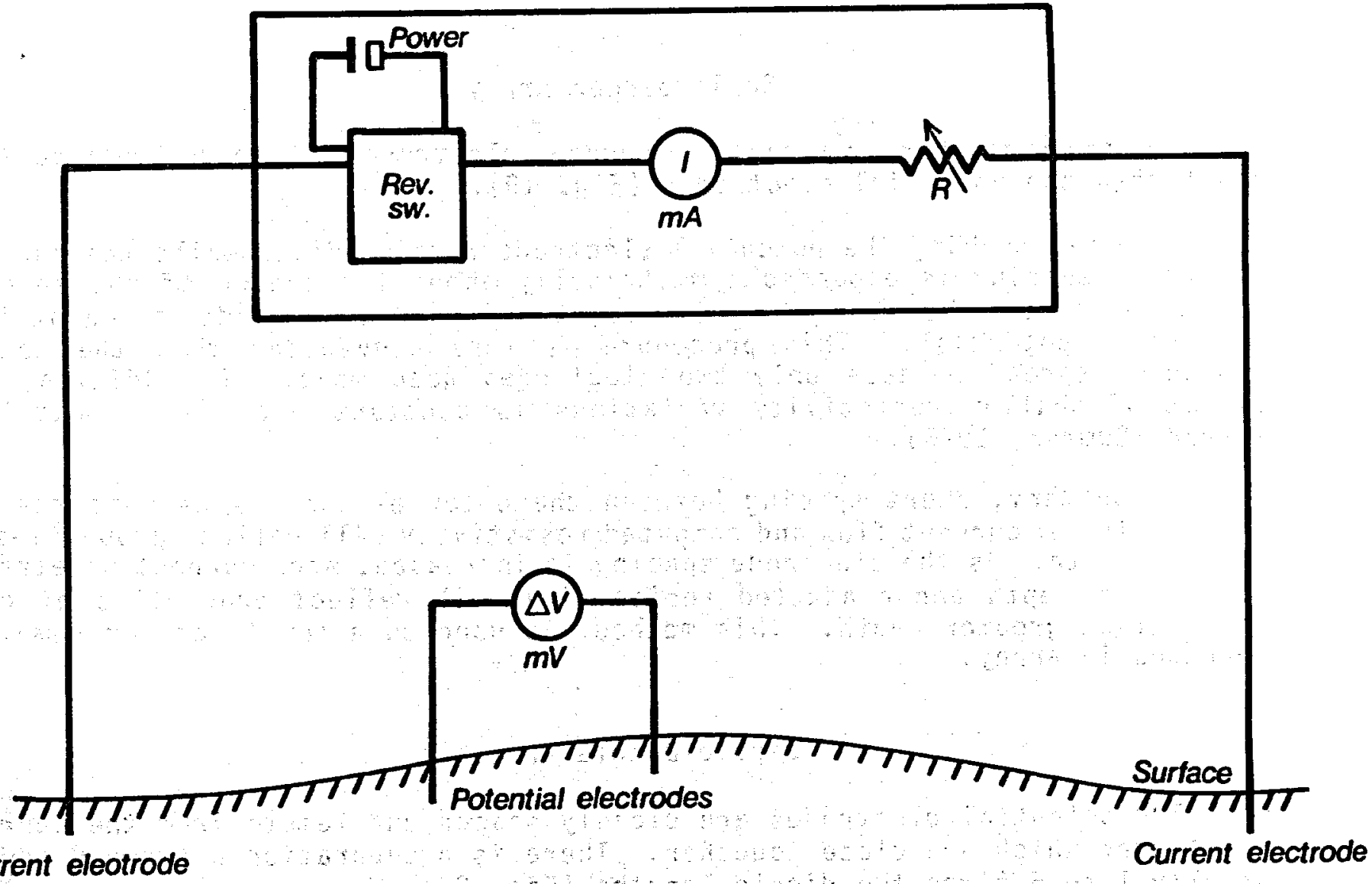

Figure 17. Schematic diagram for resistivity. (Adopted from Combs, 1980.)

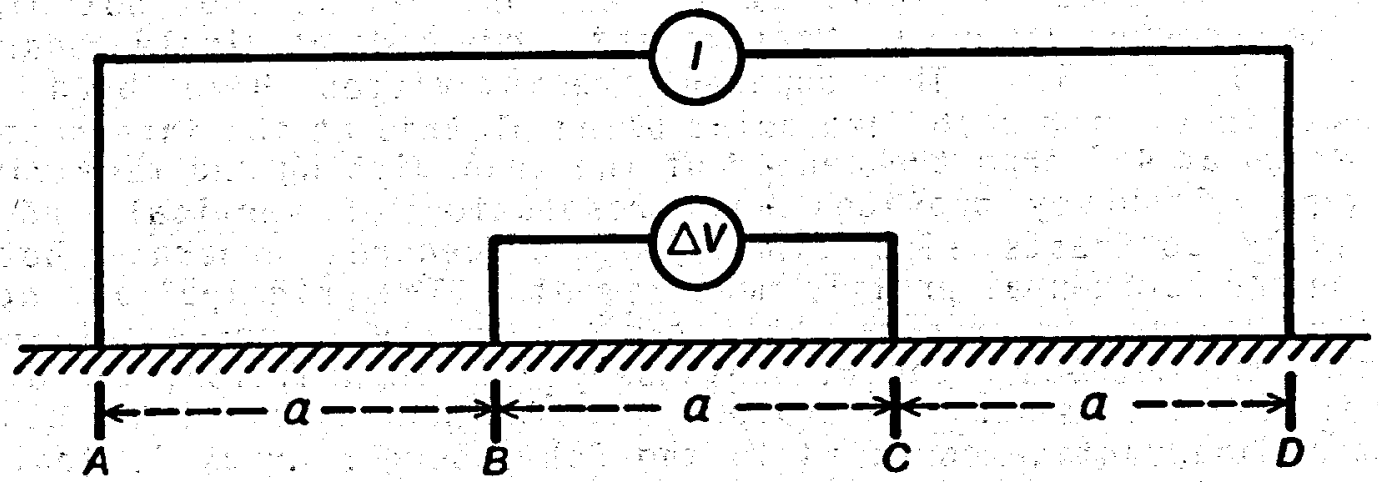

Current electrode Potential electrode Potential electrode Current electrode

$$
P_{a}=2 \pi a(\Delta v / 1)
$$

Figure 18. Wenner array. (Adopted from Combs, 1980.) 


\section{Schlumberger Array}

For the Schl umberger array, the current electrodes are spaced much further apart than the potential electrodes (Fig. 19).

In depth probing the potential electrode remains fixed while the current electrode spacing is expanded symmetrically about the center of the spread. For large values of $L$ it may be necessary to increase 21 in order to maintain a measurable potential. This procedure is more convenient than the Wenner expanding spread because only two electrodes need move. In addition, the effect of shallow resistivity variations is constant with fixed potential spread (Sumner, 1976).

In summary, short spacing between the outer electrodes assumes shallow penetration of current flow and computed resistivity will reflect properties of shallow depth. As the electrode spacing is increased, more current penetrates to greater depth and conducted resistivity will reflect properties of each material at greater depth. This method was used on a few 1 ines for sampling purposes in array.

\section{Dipole-Dipole Array}

The potential electrodes are closely spaced and remote from the current electrodes which are close together. There is a separation between $C$ and $A$, usually 1 to 5 times the dipole lengths (Fig. 20).

Inductive coupling between potential and current cables is reduced with this arrangement. This method was primarily used throughout all study areas because of reliability and ease of field operation. A diagram of this method is depicted in Figures 21 and Figure 22.

With reference to Figure 21 and 22 , an in-line 100 foot dipole-dipole electrode geometry was used. Measurements were made at dipole separations of $n$ $=1,2,3,4,5$. The apparent resistivities have been plotted as pseudosections, with each data point being plotted at the intersections of two lines drawn at $45^{\circ}$ from the center of the transmitting and receiving dipoles. This type of survey provides both resolution of vertical and horizontal resistivity contrasts since the field procedures generate both vertical sounding and horizontal profile measurements: The principal advantage of this technique is that it produces better geologically. interpretable results than the other two methods (Wenner, Schlumberger). In addition, the dipole-dipole array is easier to maneuver in rugged terrain than either of the other methods. Its main disadvantage compared to the Schlumberger array is that it usually requires more current, and therefore a heavier generator for the same penetration depth. Another disadvantage of this method is that it is very difficult to make an accurate geological interpretation from the data collected (Sumner, 1976). 


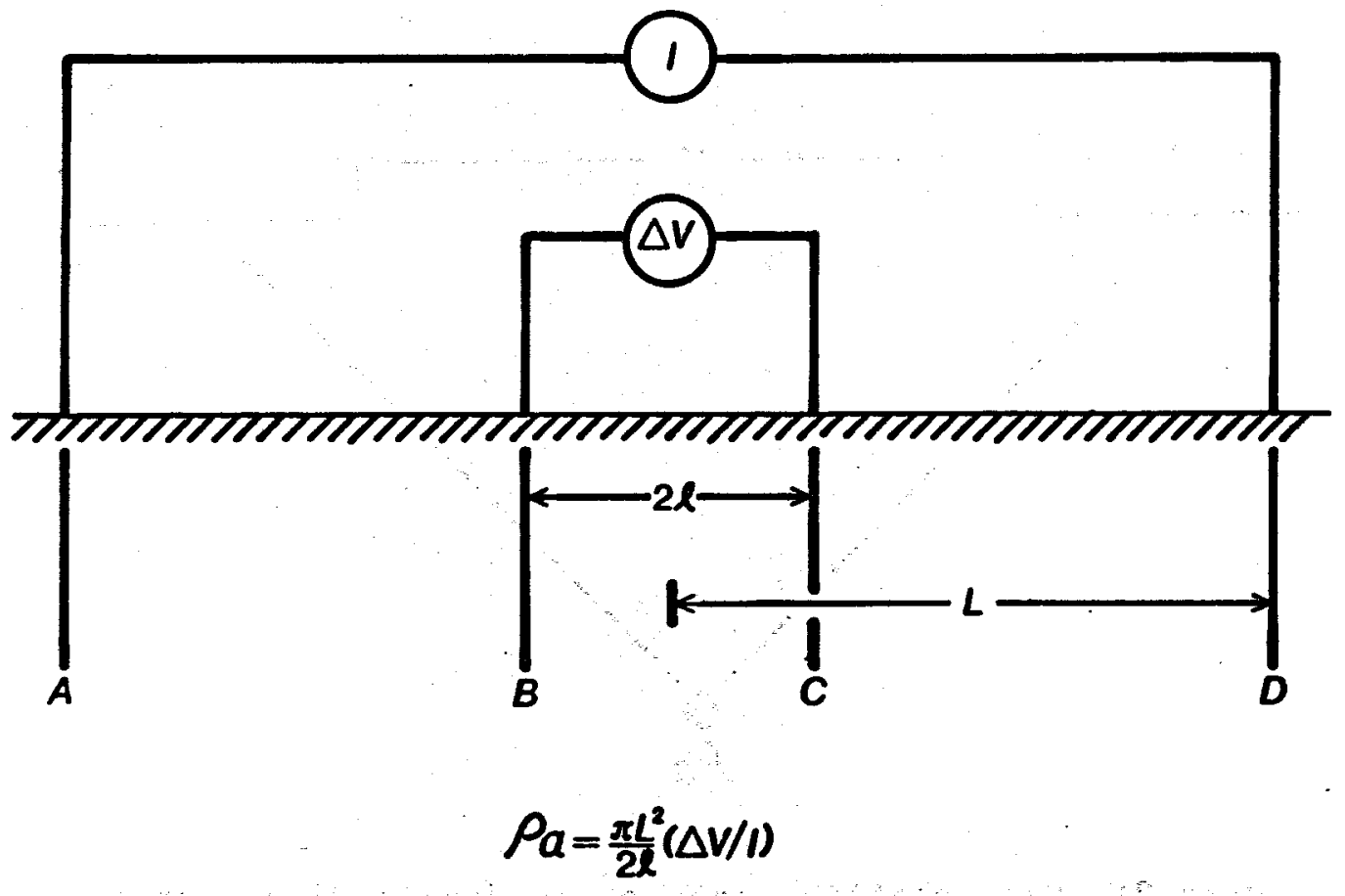

Figure 19. Schlumberger array. (Adopted from Combs, 1980.)
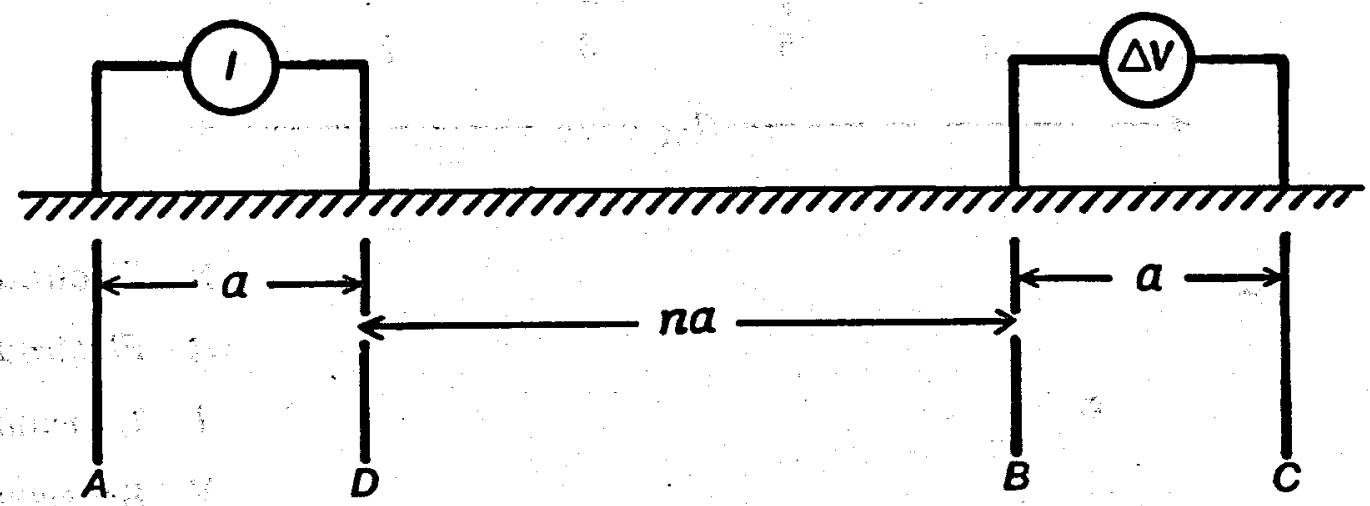

$$
\rho_{a=\pi n(n+1)(n+2) a(\Delta v / 1)}
$$

Figure 20. Dipole-dipole array. (Adopted from Combs, 1980.) 


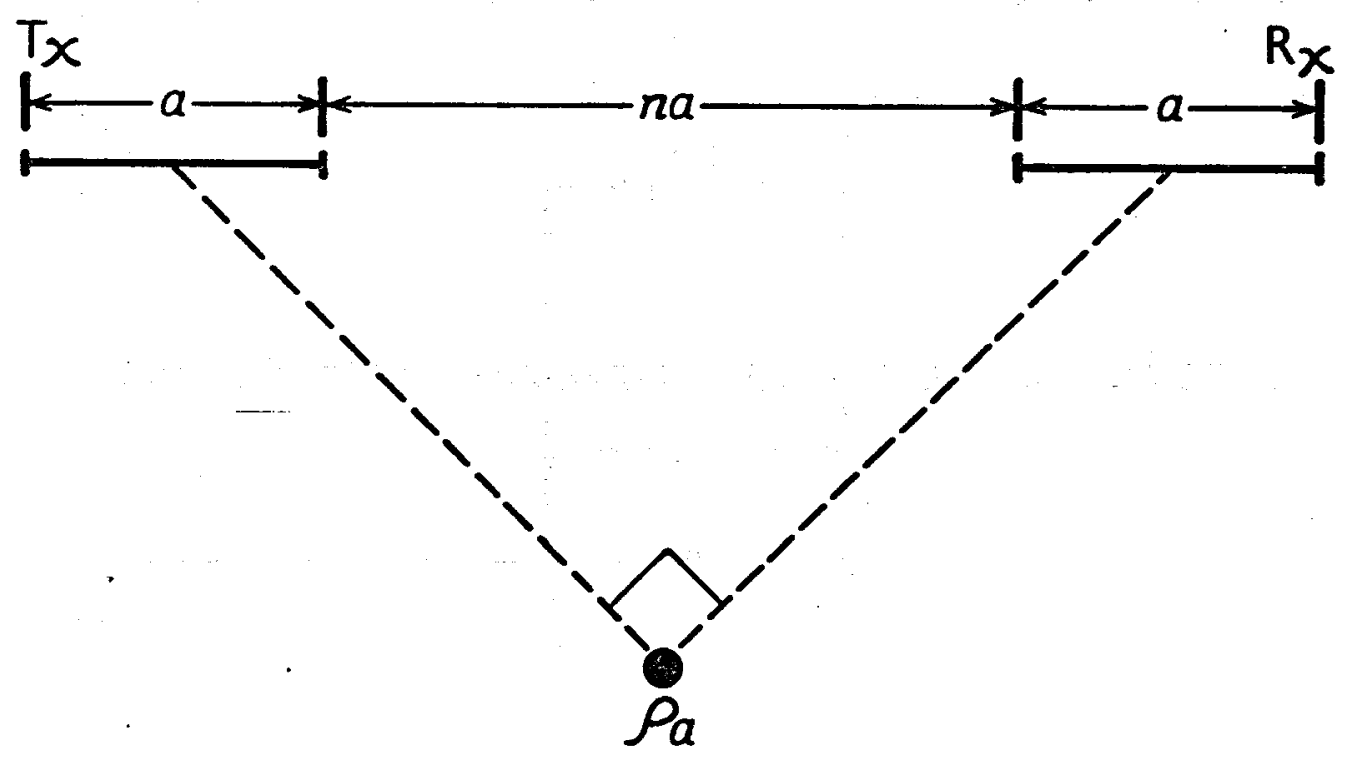

Figure 21. Data plotting scheme for dipole-dipole array. (Adopted from Combs, 1980.)

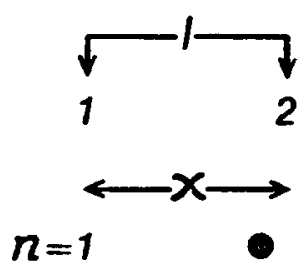

2

3

4

5

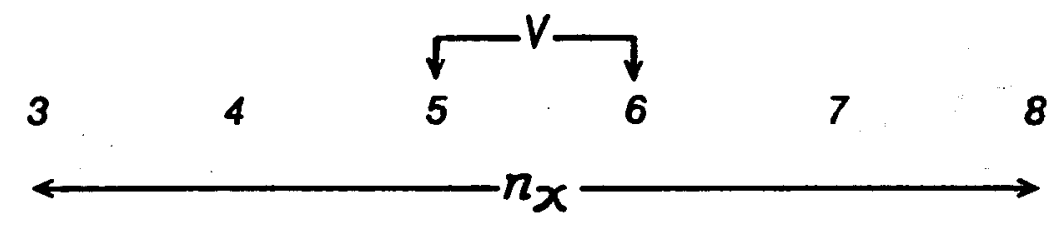

Xlectrode Spread

n Electrode Seperation

1 Transmitter

$\checkmark$ Receiver

Figure 22. Typical dipole-dipole array. (Adopted from Combs, 1980.) 


\section{APPENDIX F. RESISTIVITY CALCULATIONS}

TABLE 6. LINE A.

COLORADO GEOLOGICAL SURVEY

Geophysical Exploration

(Resistivity Survey)

\begin{tabular}{|c|c|c|c|c|c|c|c|}
\hline \multicolumn{3}{|c|}{$\begin{array}{l}\text { LOCATION } \\
\text { Hot SUTphur Spgs. } \\
\text { CHIEF OPERATOR } \\
\text { Robert Fargo } \\
\end{array}$} & \multicolumn{2}{|c|}{$\begin{array}{l}\frac{\text { PROJECT }}{\text { Line A }} \\
\text { MSSISTANTS } \\
\text { Memmi and Strong }\end{array}$} & \multicolumn{3}{|c|}{ 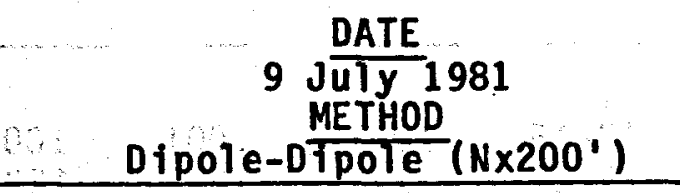 } \\
\hline Sta. & Range & $M A$ & Vol tage & $v_{p}$ & DV $/ I$ & G.F. & $P_{a}$ \\
\hline $\begin{array}{c}1-3 \\
5-7 \\
7-9 \\
9-11 \\
11-13\end{array}$ & $\begin{array}{r}10 \\
10 \\
1 \\
1\end{array}$ & $\begin{array}{l}.01 \\
.001 \\
.00031\end{array}$ & $\begin{array}{r}66 \\
66 \\
133 \\
225\end{array}$ & $\begin{array}{r}0.57 \\
0.89 \\
4.15\end{array}$ & $\begin{array}{l}0.057 \\
0.0089 \\
0.0013\end{array}$ & $\begin{array}{r}1149 \\
4997 \\
11493\end{array}$ & $\begin{array}{r}65.51 \\
44.48 \\
14.94 \\
\text { N.R. }\end{array}$ \\
\hline $\begin{array}{c}3-5 \\
7-9 \\
9-11 \\
11-13 \\
13-15 \\
15-17\end{array}$ & $\begin{array}{r}100 \\
1 \\
1 \\
1 \\
1\end{array}$ & $\begin{array}{l}.001 \\
.001 \\
.00031 \\
.00031 \\
.00031\end{array}$ & $\begin{array}{l}100 \\
100 \\
200 \\
200 \\
200\end{array}$ & $\begin{array}{r}0.67 \\
5.56 \\
4.05 \\
1.39 \\
0.66\end{array}$ & $\begin{array}{l}0.067 \\
0.00556 \\
0.0012 \\
0.0004 \\
0.0002\end{array}$ & $\begin{array}{r}1149 \\
4997 \\
11493 \\
22987 \\
40226\end{array}$ & $\begin{array}{l}77.00 \\
27.78 \\
13.79 \\
9.19 \\
8.04\end{array}$ \\
\hline $\begin{array}{l}5-7 \\
9-11 \\
11-13 \\
13-15 \\
15-17 \\
17-19\end{array}$ & $\begin{array}{r}10 \\
10 \\
10 \\
1 \\
1\end{array}$ & $\begin{array}{l}.001 \\
.001 \\
.00031 \\
.00031 \\
.00031\end{array}$ & $\begin{array}{l}100 \\
100 \\
200 \\
200 \\
200\end{array}$ & $\begin{array}{l}3.55 \\
0.58 \\
0.61 \\
2.44 \\
2.76\end{array}$ & $\begin{array}{l}0.0355 \\
0.0058 \\
0.0019 \\
0.0008 \\
0.0008\end{array}$ & $\begin{array}{r}1149 \\
4997 \\
11493 \\
22987 \\
40226\end{array}$ & $\begin{array}{l}40.80 \\
24.99 \\
21.84 \\
18.39 \\
32.18\end{array}$ \\
\hline $\begin{array}{r}7-9 \\
11-13 \\
13-15 \\
15-17 \\
17-19 \\
19-21\end{array}$ & $\begin{array}{r}100 \\
10 \\
10 \\
1 \\
1\end{array}$ & $\begin{array}{l}.00031 \\
.00031 \\
.00031 \\
.00031 \\
.00031\end{array}$ & $\begin{array}{l}133 \\
166 \\
166 \\
166 \\
166\end{array}$ & $\begin{array}{l}1.77 \\
1.63 \\
0.49 \\
2.45 \\
1.23\end{array}$ & $\begin{array}{l}0.0549 \\
0.0050 \\
0.0015 \\
0.00076 \\
0.00038\end{array}$ & $\begin{array}{r}1149 \\
4997 \\
11493 \\
22987 \\
40226\end{array}$ & $\begin{array}{l}63.06 \\
25.25 \\
17.46 \\
17.46 \\
15.34\end{array}$ \\
\hline
\end{tabular}


TABLE 6. LINE A (CONT.)

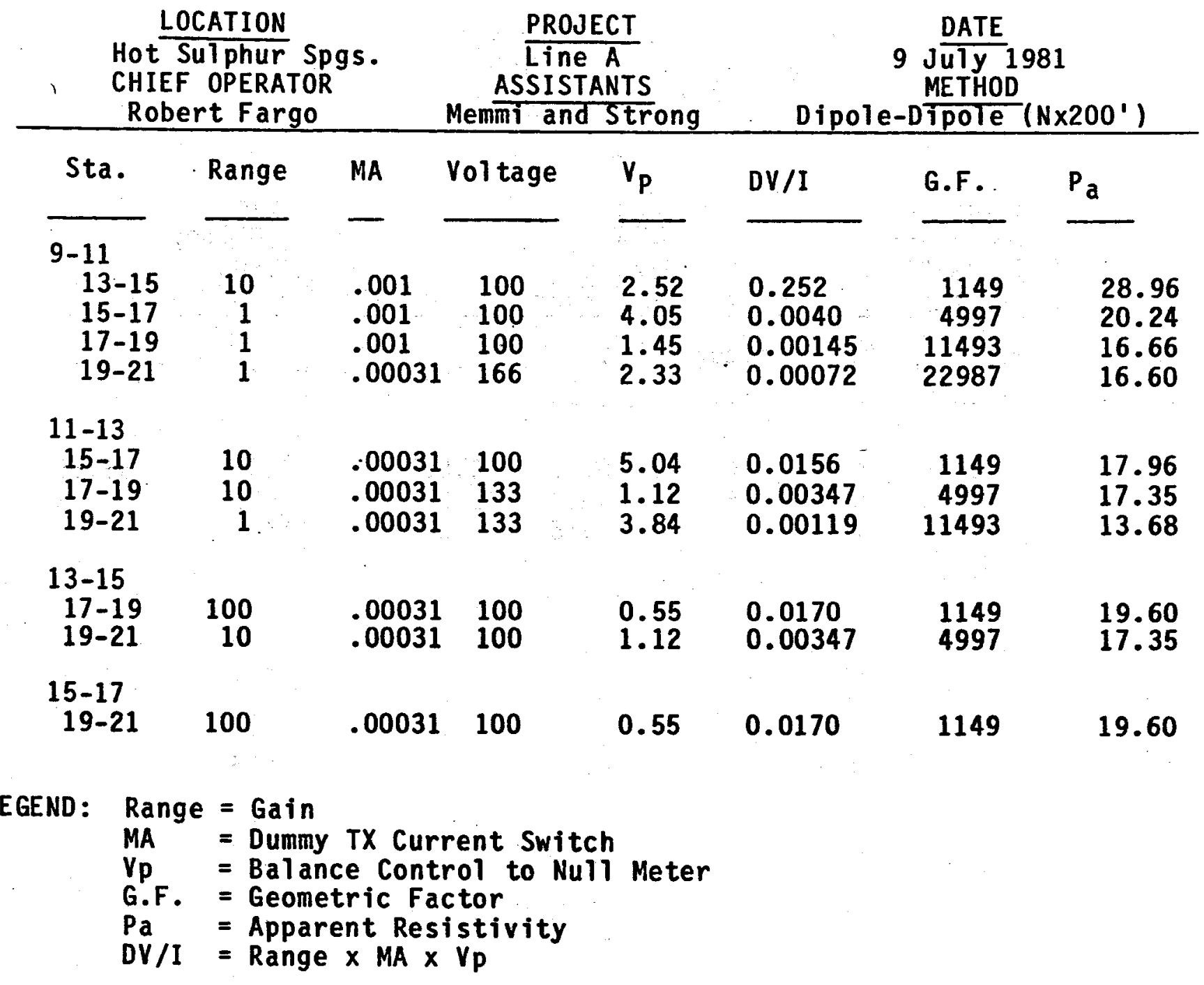




\section{APPENDIX F. RESISTIVITY CALCULATIONS}

TABLE 7. LINE B.

\section{COLORADO GEOLOGICAL SURVEY Geophysical Exploration \\ (Resistivity Survey)}

\begin{tabular}{|c|c|c|c|c|c|c|c|}
\hline \multicolumn{3}{|c|}{$\begin{array}{l}\text { LOCATION } \\
\text { Hot SU1phur Spgs. } \\
\text { CHIEF OPERATOR } \\
\text { Robert Fargo }\end{array}$} & \multicolumn{2}{|c|}{$\begin{array}{c}\text { PROJECT } \\
\frac{\text { Line } B}{\text { ASSISTANTS }} \\
\text { Memmi and Strong } \\
\end{array}$} & \multicolumn{3}{|c|}{$\begin{array}{c}10 \frac{\text { DATE }}{\text { JuTy } 1981} \\
\text { METHOD } \\
\text { Dipole-D } \frac{\text { ipoTe }}{\left.N \times 100^{\prime}\right)}\end{array}$} \\
\hline Sta. & Range & MA & Vol tage & $v_{p}$ & DV/I & G.F. & $\mathrm{Pa}_{\mathrm{a}}$ \\
\hline $\begin{array}{r}11-10 \\
9-8 \\
8-7 \\
7-6 \\
6-5 \\
5-4 \\
4-3 \\
3-2\end{array}$ & $\begin{array}{r}10 \\
1 \\
10 \\
10 \\
1 \\
1 \\
1\end{array}$ & $\begin{array}{l}.01 \\
.01 \\
.001 \\
.001 \\
.001 \\
.001 \\
.001\end{array}$ & $\begin{array}{r}66 \\
100\end{array}$ & $\begin{array}{l}0.77 \\
2.30 \\
0.98 \\
0.52 \\
2.38 \\
2.24 \\
1.30\end{array}$ & $\begin{array}{l}0.077 \\
0.0230 \\
0.0098 \\
0.0054 \\
0.00238 \\
0.00224 \\
0.00130\end{array}$ & $\begin{array}{r}575 \\
2299 \\
5747 \\
11493 \\
20113 \\
32181 \\
47698\end{array}$ & $\begin{array}{l}44.25 \\
52.87 \\
51.72 \\
62.06 \\
47.87 \\
72.09 \\
62.01\end{array}$ \\
\hline $\begin{array}{r}10-9 \\
8-7 \\
7-6 \\
6-5 \\
5-4 \\
4-3 \\
3-2 \\
2-1\end{array}$ & $\begin{array}{r}100 \\
10 \\
10 \\
1 \\
1 \\
1 \\
1\end{array}$ & $\begin{array}{l}.001 \\
.001 \\
.001 \\
.001 \\
.001 \\
.001 \\
.001\end{array}$ & $\begin{array}{l}66 \\
66 \\
66 \\
66 \\
66 \\
66 \\
66\end{array}$ & $\begin{array}{l}0.62 \\
1.75 \\
0.82 \\
3.54 \\
3.01 \\
1.71 \\
0.68\end{array}$ & $\begin{array}{l}0.062 \\
0.0175 \\
0.0082 \\
0.00354 \\
0.00301 \\
0.00171 \\
0.00068\end{array}$ & $\begin{array}{r}575 \\
2299 \\
5747 \\
11493 \\
20113 \\
32182 \\
47698\end{array}$ & $\begin{array}{l}35.63 \\
40.23 \\
47.12 \\
40.69 \\
60.54 \\
55.03 \\
32.42\end{array}$ \\
\hline $\begin{array}{r}9-8 \\
7-6 \\
6-5 \\
5-4 \\
4-3 \\
3-2 \\
2-1\end{array}$ & $\begin{array}{r}100 \\
10 \\
10 \\
10 \\
10 \\
1\end{array}$ & $\begin{array}{l}.001 \\
.001 \\
.001 \\
.001 \\
.001 \\
.001\end{array}$ & 66 & $\begin{array}{l}0.68 \\
2.40 \\
0.87 \\
0.70 \\
0.41 \\
1.46\end{array}$ & $\begin{array}{l}0.0680 \\
0.0240 \\
0.0087 \\
0.0070 \\
0.00415 \\
0.00146\end{array}$ & $\begin{array}{r}575 \\
2299 \\
5747 \\
11493 \\
20113 \\
32182\end{array}$ & $\begin{array}{l}39.08 \\
55.17 \\
50.00 \\
80.45 \\
82.46 \\
46.98\end{array}$ \\
\hline $\begin{array}{r}8-7 \\
6-5 \\
5-4 \\
4-3 \\
3-2 \\
2-1\end{array}$ & $\begin{array}{r}100 \\
10 \\
10 \\
10 \\
1\end{array}$ & $\begin{array}{l}.001 \\
.001 \\
.001 \\
.001 \\
.001\end{array}$ & 66 & $\begin{array}{l}0.66 \\
1.47 \\
1.05 \\
0.55 \\
2.02\end{array}$ & $\begin{array}{l}0.066 \\
0.0147 \\
0.0105 \\
0.0055 \\
0.0020\end{array}$ & $\begin{array}{r}575 \\
2299 \\
5747 \\
11493 \\
20113\end{array}$ & $\begin{array}{l}37.93 \\
33.79 \\
60.34 \\
63.21 \\
40.63\end{array}$ \\
\hline
\end{tabular}


TABLE 7. LINE B (CONT.)

\begin{tabular}{|c|c|c|c|c|c|c|c|}
\hline \multicolumn{3}{|c|}{$\begin{array}{l}\text { Lot SUTphur Spgs. } \\
\text { CHIEF OPERATOR } \\
\text { Robert Fargo }\end{array}$} & \multicolumn{2}{|c|}{$\begin{array}{c}\text { PROJECT } \\
\text { Line B } \\
\text { ASSISTANTS } \\
\text { Memmi and Strong }\end{array}$} & \multicolumn{3}{|c|}{ 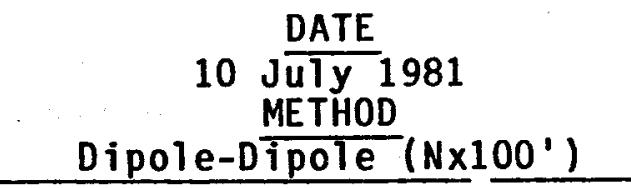 } \\
\hline Sta. & Range & MA & Voltage & $v_{p}$ & $\mathrm{DV} / \mathrm{I}$ & G.F. & $\mathrm{Pa}_{\mathrm{a}}$ \\
\hline $\begin{array}{r}7-6 \\
5-4 \\
4-3 \\
3-2 \\
2-1\end{array}$ & $\begin{array}{r}100 \\
10 \\
10 \\
1\end{array}$ & $\begin{array}{l}.001 \\
.001 \\
.001 \\
.001\end{array}$ & 66 & $\begin{array}{l}0.41 \\
1.79 \\
0.82 \\
2.85\end{array}$ & $\begin{array}{l}0.041 \\
0.0179 \\
0.0082 \\
0.00285\end{array}$ & $\begin{array}{r}575 \\
2299 \\
5747 \\
11493\end{array}$ & $\begin{array}{l}23.56 \\
41.15 \\
47.12 \\
32.76\end{array}$ \\
\hline $\begin{array}{r}6-5 \\
4-3 \\
3-2 \\
2-1\end{array}$ & $\begin{array}{r}100 \\
10 \\
10\end{array}$ & $\begin{array}{l}.001 \\
.001 \\
.001\end{array}$ & 66 & $\begin{array}{l}0.98 \\
1.49 \\
0.46\end{array}$ & $\begin{array}{l}0.50 \\
0.0149 \\
0.0046\end{array}$ & $\begin{array}{r}575 \\
2299 \\
5747\end{array}$ & $\begin{array}{l}28.73 \\
34.25 \\
26.43\end{array}$ \\
\hline $\begin{array}{r}5-4 \\
3-2 \\
2-1\end{array}$ & $\begin{array}{l}10 \\
10\end{array}$ & $\begin{array}{l}.001 \\
.001\end{array}$ & 100 & $\begin{array}{l}3.67 \\
0.84\end{array}$ & $\begin{array}{l}0.367 \\
0.0084\end{array}$ & $\begin{array}{r}575 \\
2299\end{array}$ & $\begin{array}{l}21.09 \\
19.31\end{array}$ \\
\hline $\begin{array}{l}4-3 \\
2-1\end{array}$ & 100 & .001 & 100 & 0.67 & 0.067 & 575 & 38.50 \\
\hline
\end{tabular}

LEGEND: Range $=$ Gain

MA = Dummy TX Current Switch

$V_{p}=$ Balance Control to Null Meter

G.F. = Geometric Factor

$\mathrm{Pa}$ = Apparent Resistivity

$\mathrm{DV} / \mathrm{I}=$ Range $\times$ MA $\times V_{\mathrm{p}}$ 


\section{APPENDIX F. RESISTIVITY CALCULATIONS}

TABLE 8. LINE C.

\section{COLORADO GEOLOGICAL SURVEY \\ Geophysical Exploration \\ (Resistivity Survey)}

\begin{tabular}{|c|c|c|c|c|c|c|c|}
\hline \multicolumn{3}{|c|}{$\begin{array}{l}\text { LOCATION } \\
\text { Hot SUTphur Spgs } \\
\text { CHIEF OPERATOR } \\
\text { Robert Fargo } \\
\end{array}$} & \multicolumn{2}{|c|}{$\begin{array}{c}\text { PROJECT } \\
\text { Line C } \\
\text { ASSISTANTS } \\
\text { Memmi and Strong }\end{array}$} & \multicolumn{3}{|c|}{ 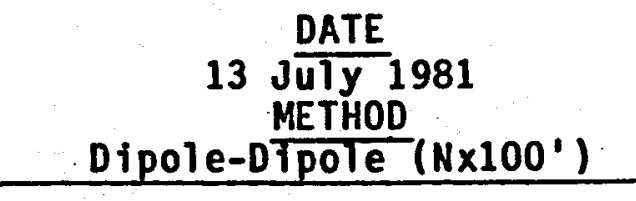 } \\
\hline Sta. & Range & MA & Voltage & $v_{p}$ & $\mathrm{DV} / \mathrm{I}$ & G.F. & $\mathrm{Pa}_{\mathrm{a}}$ \\
\hline $\begin{array}{c}1-2 \\
3-4 \\
4-5 \\
5-6 \\
6-7 \\
7-8 \\
8-9 \\
9-10\end{array}$ & $\begin{array}{r}100 \\
10 \\
10 \\
10 \\
10 \\
10 \\
1\end{array}$ & $\begin{array}{l}.001 \\
.001 \\
.001 \\
.001 \\
.001 \\
.001 \\
.001\end{array}$ & 166 & $\begin{array}{l}1.99 \\
3.31 \\
1.65 \\
0.73 \\
0.35 \\
0.29 \\
1.72\end{array}$ & $\begin{array}{l}0.1990 \\
0.0331 \\
0.0165 \\
0.0073 \\
0.0035 \\
0.0029 \\
0.00172\end{array}$ & $\begin{array}{r}575 \\
2299 \\
5747 \\
11493 \\
20113 \\
32181 \\
47698\end{array}$ & $\begin{array}{r}114.36 \\
76.09 \\
94.82 \\
83.90 \\
70.40 \\
93.33 \\
82.04\end{array}$ \\
\hline $\begin{array}{c}2-3 \\
4-5 \\
5-6 \\
6-7 \\
7-8 \\
8-9 \\
9-10 \\
10-11\end{array}$ & $\begin{array}{r}100 \\
100 \\
10 \\
10 \\
10 \\
10 \\
1\end{array}$ & $\begin{array}{l}.001 \\
.001 \\
.001 \\
.001 \\
.001 \\
.001 \\
.001\end{array}$ & 133 & $\begin{array}{l}1.92 \\
0.76 \\
2.95 \\
1.25 \\
0.90 \\
0.55 \\
3.71\end{array}$ & $\begin{array}{l}0.1925 \\
0.0765 \\
0.0295 \\
0.0125 \\
0.0090 \\
0.0550 \\
0.00371\end{array}$ & $\begin{array}{r}574 \\
2299 \\
5747 \\
11493 \\
20113 \\
32181 . \\
47698\end{array}$ & $\begin{array}{l}110.34 \\
174.70 \\
169.53 \\
143.67 \\
181.02 \\
177.00 \\
176.96\end{array}$ \\
\hline $\begin{array}{c}3-4 \\
5-6 \\
6-7 \\
7-8 \\
8-9 \\
9-10 \\
10-11 \\
11-12\end{array}$ & $\begin{array}{r}100 \\
10 \\
10 \\
10 \\
10 \\
10 \\
10\end{array}$ & $\begin{array}{l}.001 \\
.001 \\
.001 \\
.001 \\
.001 \\
.001 \\
.001\end{array}$ & $\begin{array}{l}166 \\
200\end{array}$ & $\begin{array}{l}1.16 \\
3.15 \\
1.16 \\
0.83 \\
0.52 \\
0.31 \\
0.15 \star\end{array}$ & $\begin{array}{l}0.116 \\
0.0315 \\
0.0116 \\
0.0083 \\
0.0052 \\
0.0031 \\
0.0015\end{array}$ & $\begin{array}{r}575 \\
2299 \\
5747 \\
11493 \\
20113 \\
32182 \\
47697\end{array}$ & $\begin{array}{r}66.66 \\
72.41 \\
66.66 \\
95.39 \\
104.59 \\
99.76 \\
71.55\end{array}$ \\
\hline $\begin{array}{c}4-5 \\
6-7 \\
7-8 \\
8-9 \\
9-10 \\
10-11 \\
11-12\end{array}$ & $\begin{array}{r}100 \\
10 \\
10 \\
10 \\
10 \\
10\end{array}$ & $\begin{array}{l}.001 \\
.001 \\
.001 \\
.001 \\
.001 \\
.001\end{array}$ & 166 & $\begin{array}{l}0.88 \\
1.86 \\
1.06 \\
0.68 \\
0.40 \\
0.20\end{array}$ & $\begin{array}{l}0.088 \\
0.0186 \\
0.0106 \\
0.0068 \\
0.0040 \\
0.0020\end{array}$ & $\begin{array}{r}575 \\
2299 \\
5747 \\
11493 \\
20113 \\
32182\end{array}$ & $\begin{array}{l}50.57 \\
42.75 \\
60.91 \\
78.15 \\
80.45 \\
64.36\end{array}$ \\
\hline
\end{tabular}


TABLE 8. LINE C (CONT.)

\begin{tabular}{|c|c|c|c|c|c|c|c|}
\hline \multicolumn{3}{|c|}{$\begin{array}{l}\text { LOCATION } \\
\text { Hot SUTphur Spgs } \\
\text { CHIEF OPERATOR } \\
\text { Robert Fargo } \\
\end{array}$} & \multicolumn{2}{|c|}{$\begin{array}{c}\text { PROJECT } \\
\text { Line C } \\
\text { ASSISTANTS }\end{array}$} & \multicolumn{3}{|c|}{$\begin{array}{c}13 \frac{\text { DATE }}{\text { JuTy } 1981} \\
\text { METHOD } \\
\text { Dipole-Dipole }\left(\mathrm{N} \times 100^{\prime}\right)\end{array}$} \\
\hline Sta. & Range & MA & Voltage & $v_{p}$ & $\mathrm{DV} / \mathrm{I}$ & G.F. & $\mathrm{Pa}_{\mathrm{a}}$ \\
\hline $\begin{array}{c}5-6 \\
7-8 \\
8-9 \\
9-10 \\
10-11 \\
11-12\end{array}$ & $\begin{array}{r}100 \\
10 \\
10 \\
10 \\
10\end{array}$ & $\begin{array}{l}.001 \\
.001 \\
.001 \\
.001 \\
.001\end{array}$ & 133 & $\begin{array}{l}0.55 \\
2.21 \\
1.20 \\
0.69 \\
0.30\end{array}$ & $\begin{array}{l}0.055 \\
0.0221 \\
0.0120 \\
0.0069 \\
0.0030\end{array}$ & $\begin{array}{r}575 \\
2299 \\
5747 \\
11493 \\
20113\end{array}$ & $\begin{array}{l}31.61 \\
50.80 \\
68.96 \\
79.30 \\
60.34\end{array}$ \\
\hline $\begin{array}{c}6-7 \\
8-9 \\
9-10 \\
10-11 \\
11-12\end{array}$ & $\begin{array}{r}100 \\
10 \\
10 \\
10\end{array}$ & $\begin{array}{l}.001 \\
.001 \\
.001 \\
.001\end{array}$ & 133 & $\begin{array}{l}0.61 \\
2.16 \\
1.08 \\
0.47\end{array}$ & $\begin{array}{l}0.0610 \\
0.0216 \\
0.0108 \\
0.0047\end{array}$ & $\begin{array}{r}575 \\
2299 \\
5747 \\
11493\end{array}$ & $\begin{array}{l}35.05 \\
49.65 \\
62.06 \\
54.02\end{array}$ \\
\hline $\begin{array}{r}7-8 \\
9-10 \\
10-11 \\
11-12\end{array}$ & $\begin{array}{r}100 \\
10 \\
10\end{array}$ & $\begin{array}{l}.001 \\
.001 \\
.001\end{array}$ & 100 & $\begin{array}{l}0.56 \\
1.80 \\
0.81\end{array}$ & $\begin{array}{l}0.0560 \\
0.0180 \\
0.0081\end{array}$ & $\begin{array}{r}575 \\
2299 \\
5747\end{array}$ & $\begin{array}{l}32.18 \\
41.38 \\
46.55\end{array}$ \\
\hline $\begin{array}{l}8-9 \\
10-11 \\
11-12\end{array}$ & $\begin{array}{r}100 \\
10\end{array}$ & $\begin{array}{l}.001 \\
.001\end{array}$ & 100 & $\begin{array}{l}0.75 \\
2.11\end{array}$ & $\begin{array}{l}0.075 \\
0.0211\end{array}$ & $\begin{array}{r}575 \\
2299\end{array}$ & $\begin{array}{l}43.10 \\
48.50\end{array}$ \\
\hline $\begin{array}{l}9-10 \\
11-12\end{array}$ & 100 & .001 & 100 & 0.71 & 0.071 & 575 & 40.80 \\
\hline $\begin{array}{l}\text { ND: } \\
\text { lange }= \\
\text { IA }= \\
\mathrm{p}=\end{array}$ & $\begin{array}{l}\text { ny } T X \\
\text { ance }\end{array}$ & $\begin{array}{l}\text { rent } \\
\text { rol }\end{array}$ & $\begin{array}{l}\text { tch } \\
\text { lul1 }\end{array}$ & & $\begin{aligned} \mathrm{F} . & =\mathrm{Ge} \\
& =\mathrm{Ap} \\
/ \mathrm{I} & =\mathrm{Ra}\end{aligned}$ & $\begin{array}{l}\text { nt Res } \\
X \text { MA } X\end{array}$ & vity \\
\hline
\end{tabular}




\section{APPENDIX F. RESISTIVITY CALCULATIONS}

TABLE 9. LINE D

\section{COLORADO GEOLOGICAL SURVEY \\ Geophysical Exploration \\ (Resistivity Survey)}

\begin{tabular}{|c|c|c|c|c|c|c|c|}
\hline \multicolumn{3}{|c|}{$\begin{array}{l}\text { Hot SOCATION } \\
\text { CHIEF OPER Spgs } \\
\text { Robert Fargo } \\
\end{array}$} & \multicolumn{2}{|c|}{$\begin{array}{c}\text { PROJECT } \\
\text { [ine D } \\
\text { ASSISTANTS }\end{array}$} & \multicolumn{3}{|c|}{ 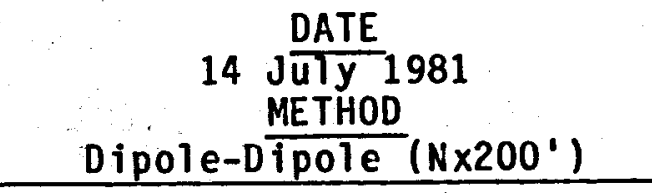 } \\
\hline Sta. & Range & MA & Voltage & $v_{p}$ & $\mathrm{DV} / \mathrm{I}$ & G.F. & $\mathrm{Pa}_{\mathrm{a}}$ \\
\hline $\begin{array}{c}1-3 \\
5-7 \\
7-9 \\
9-11 \\
11-13 \\
13-15\end{array}$ & $\begin{array}{r}100 \\
10 \\
10 \\
10 \\
1\end{array}$ & $\begin{array}{l}.001 \\
.001 \\
.001 \\
.001 \\
.00031\end{array}$ & 133 & $\begin{array}{l}0.39 \\
0.75 \\
0.48 \\
1.52 \\
1.52\end{array}$ & $\begin{array}{l}0.039 \\
0.0075 \\
0.0048 \\
0.00152 \\
0.00047\end{array}$ & $\begin{array}{r}1149 \\
4997 \\
1493 \\
22986 \\
40226\end{array}$ & $\begin{array}{l}44.82 \\
37.48 \\
55.17 \\
34.94 \\
18.95\end{array}$ \\
\hline $\begin{array}{l}3-5 \\
7-9 \\
9-11 \\
11-13 \\
13-15 \\
15-17\end{array}$ & $\begin{array}{r}10 \\
10 \\
10 \\
1 \\
1\end{array}$ & $\begin{array}{l}.001 \\
.001 \\
.00031 \\
.00031 \\
.00031\end{array}$ & $\begin{array}{l}66 \\
100 \\
100\end{array}$ & $\begin{array}{l}2.35 \\
0.07 \\
0.98 \\
2.51 \\
1.28\end{array}$ & $\begin{array}{l}0.0235 \\
0.0107 \\
0.00304 \\
0.00075 \\
0.00040\end{array}$ & $\begin{array}{r}1149 \\
4997 \\
11493 \\
22986 \\
40226\end{array}$ & $\begin{array}{l}27.01 \\
53.47 \\
34.94 \\
17.31 \\
15.97\end{array}$ \\
\hline $\begin{array}{r}5-7 \\
9-11 \\
11-13 \\
13-15 \\
15-17 \\
17-19\end{array}$ & $\begin{array}{r}10 \\
10 \\
1 \\
1 \\
1\end{array}$ & $\begin{array}{l}.001 \\
.001 \\
.001 \\
.00031 \\
.00031\end{array}$ & $\begin{array}{l}66 \\
1 \\
1\end{array}$ & $\begin{array}{l}3.65 \\
0.74 \\
1.62 \\
2.60 \\
1.56\end{array}$ & $\begin{array}{l}0.0365 \\
0.0074 \\
0.00162 \\
0.00081 \\
0.00048\end{array}$ & $\begin{array}{r}1149 \\
4997 \\
11493 \\
22986 \\
40226\end{array}$ & $\begin{array}{l}41.95 \\
36.98 \\
18.62 \\
18.53 \\
19.47\end{array}$ \\
\hline $\begin{array}{l}7-9 \\
11-13 \\
13-15 \\
15-17 \\
17-19 \\
19-21\end{array}$ & $\begin{array}{r}10 \\
1 \\
1 \\
1 \\
1\end{array}$ & $\begin{array}{l}.001 \\
.001 \\
.00031 \\
.00031 \\
.00031\end{array}$ & $\begin{array}{l}100 \\
1 \\
166 \\
1 \\
1\end{array}$ & $\begin{array}{l}1.65 \\
2.69 \\
3.65 \\
1.95 \\
1.23\end{array}$ & $\begin{array}{l}0.0165 \\
0.0027 \\
0.001135 \\
0.000605 \\
0.000381\end{array}$ & $\begin{array}{r}1149 \\
4997 \\
11493 \\
22986 \\
40226\end{array}$ & $\begin{array}{l}18.96 \\
13.44 \\
13.04 \\
13.91 \\
15.33\end{array}$ \\
\hline $\begin{array}{l}9-11 \\
13-15 \\
15-17 \\
17-19 \\
19-21 \\
21-23\end{array}$ & $\begin{array}{r}10 \\
10 \\
1 \\
1 \\
1\end{array}$ & $\begin{array}{l}.001 \\
.001 \\
.001 \\
.00031 \\
.00031\end{array}$ & $\begin{array}{l}100 \\
1 \quad 200 \\
1\end{array}$ & $\begin{array}{l}1.53 \\
0.41 \\
1.91 \\
3.21 \\
1.77\end{array}$ & $\begin{array}{l}0.0153 \\
0.0041 \\
0.00191 \\
0.00100 \\
0.000549\end{array}$ & $\begin{array}{r}1149 \\
4997 \\
11493 \\
22986 \\
40226\end{array}$ & $\begin{array}{l}17.58 \\
20.49 \\
21.95 \\
22.87 \\
22.08\end{array}$ \\
\hline
\end{tabular}


TABLE 9. LINE D (CONT.)

\begin{tabular}{|c|c|c|c|c|c|c|c|c|}
\hline & $\begin{array}{l}\text { LOC } \\
\text { ot } \frac{\text { SI }}{\text { HIEF }} \\
\text { obert }\end{array}$ & $\begin{array}{l}\text { ATION } \\
\text { ITphur } \\
\text { OPERAT } \\
\text { Fargo }\end{array}$ & & $\begin{array}{r}\text { PRO } \\
\text { Lin } \\
\text { ASSIS } \\
\text { Memi an } \\
\end{array}$ & $\begin{array}{l}\frac{C T}{D} \\
\text { NTS } \\
\text { Strong } \\
\end{array}$ & Dipole & $\begin{array}{l}\text { DATE } \\
\text { July } \\
\text { METHOD } \\
\text { DipoTe } \\
\end{array}$ & $\begin{array}{r}1 \\
\times 200^{\prime} 1 \\
\end{array}$ \\
\hline Sta. & & Range & MA & Vol tage & $v_{p}$ & $\mathrm{DV} / \mathrm{I}$ & G.F. & $\mathrm{Pa}$ \\
\hline $\begin{array}{r}11-13 \\
15-1 \\
17-1 \\
19-2 \\
21-2\end{array}$ & & $\begin{array}{r}10 \\
10 \\
1 \\
1\end{array}$ & $\begin{array}{l}.001 \\
.001 \\
.001 \\
.00031\end{array}$ & 200 & $\begin{array}{l}1.45 \\
0.45 \\
1.94 \\
2.88\end{array}$ & $\begin{array}{l}0.0145 \\
0.0045 \\
0.00195 \\
0.000893\end{array}$ & $\begin{array}{r}1149 \\
4997 \\
11493 \\
22986\end{array}$ & $\begin{array}{l}16.66 \\
22.49 \\
22.41 \\
20.53\end{array}$ \\
\hline $\begin{array}{r}13-15 \\
17-1 \\
19-2 \\
21-2\end{array}$ & & $\begin{array}{r}10 \\
10 \\
1\end{array}$ & $\begin{array}{l}.001 \\
.001 \\
.001\end{array}$ & $\begin{array}{l}66 \\
66\end{array}$ & $\begin{array}{l}1.63 \\
0.47 \\
1.52\end{array}$ & $\begin{array}{l}0.0163 \\
0.0047 \\
0.00152\end{array}$ & $\begin{array}{r}1149 \\
4997 \\
11493\end{array}$ & $\begin{array}{l}18.73 \\
23.49 \\
17.47\end{array}$ \\
\hline $\begin{array}{r}15-17 \\
19-2 \\
21-2\end{array}$ & & $\begin{array}{l}10 \\
10\end{array}$ & $\begin{array}{l}.001 \\
.001\end{array}$ & 66 & $\begin{array}{l}2.17 \\
0.40\end{array}$ & $\begin{array}{l}0.0217 \\
0.0040\end{array}$ & $\begin{array}{l}1149 \\
4997\end{array}$ & $\begin{array}{l}24.94 \\
19.99\end{array}$ \\
\hline $\begin{array}{r}17-19 \\
21-2\end{array}$ & & 10 & .001 & 66 & 1.63 & 0.0163 & 1149 & 18.73 \\
\hline EGEND: & $\begin{array}{l}\text { Range } \\
\text { MA } \\
V_{p} \\
G . F . \\
P a \\
D V / I\end{array}$ & $\begin{array}{l}=\text { Gai } \\
=\text { Dum } \\
=\text { BaI } \\
=\text { Geo } \\
=\text { App } \\
=\text { Ran }\end{array}$ & $\begin{array}{l}\text { TX Cu } \\
\text { e Con } \\
\text { ric F } \\
\text { nt Re } \\
x \text { MA }\end{array}$ & $\begin{array}{l}\text { rent Swit } \\
\text { rol to NL } \\
\text { ctor } \\
\text { istivity } \\
V_{p}\end{array}$ & Meter & & & \\
\hline
\end{tabular}




\section{APPENDIX F. RESISTIVITY CALCULATIONS}

TABLE 10. LINE E.

COLORADO GEOLOGICAL SURVEY

Geophysical Exploration

(Resistivity Survey)

LOCATION

Hot SuTphur Spgs

CHIEF OPERATOR

Robert Fargo
PROJECT

Line $\mathrm{E}$

ASSISTANTS

Memmi and Strong
DATE

15 Juाy 1981

METHOD Dipole-Dipole $\left(\mathrm{N} \times 100^{\prime}\right)$

\begin{tabular}{|c|c|c|c|c|c|c|c|}
\hline Sta. & Range & MA & Voltage & $v_{p}$ & $\mathrm{DV} / \mathrm{I}$ & G.F. & $P_{a}$ \\
\hline $\begin{array}{c}5-6 \\
7-8 \\
8-9 \\
9-10 \\
10-11 \\
11-12 \\
12-13\end{array}$ & $\begin{array}{r}100 \\
10 \\
10 \\
1 \\
1 \\
1\end{array}$ & $\begin{array}{l}.001 \\
.001 \\
.001 \\
.001 \\
.001 \\
.001\end{array}$ & 200 & $\begin{array}{l}0.66 \\
1.24 \\
0.44 \\
2.03 \\
0.94 \\
0.48\end{array}$ & $\begin{array}{l}0.066 \\
0.0124 \\
0.0044 \\
0.00203 \\
0.00094 \\
0.00048\end{array}$ & $\begin{array}{r}574 \\
2298 \\
5746 \\
20113 \\
20113 \\
32181\end{array}$ & $\begin{array}{l}38.13 \\
28.50 \\
25.29 \\
18.91 \\
18.91 \\
15.13\end{array}$ \\
\hline $\begin{array}{r}6-7 \\
8-9 \\
9-10 \\
10-11 \\
11-12 \\
12-13 \\
13-14\end{array}$ & $\begin{array}{r}10 \\
10 \\
10 \\
1 \\
1 \\
1\end{array}$ & $\begin{array}{l}.001 \\
.001 \\
.001 \\
.001 \\
.001 \\
.001\end{array}$ & 133 & $\begin{array}{l}4.92 \\
0.87 \\
0.37 \\
0.93 \\
0.94 \\
0.47\end{array}$ & $\begin{array}{l}0.0492 \\
0.0087 \\
0.0037 \\
0.00093 \\
0.00094 \\
0.00047\end{array}$ & $\begin{array}{r}574 \\
2298 \\
5746 \\
11493 \\
20113 \\
32181\end{array}$ & $\begin{array}{l}28.27 \\
20.00 \\
21.26 \\
10.69 \\
18.91 \\
15.13\end{array}$ \\
\hline $\begin{array}{c}7-8 \\
9-10 \\
10-11 \\
11-12 \\
12-13 \\
13-14\end{array}$ & $\begin{array}{r}100 \\
10 \\
10 \\
10 \\
10\end{array}$ & $\begin{array}{l}.001 \\
.001 \\
.001 \\
.001 \\
.00031\end{array}$ & $\begin{array}{l}100 \\
200\end{array}$ & $\begin{array}{l}0.57 \\
1.04 \\
0.41 \\
0.49 \\
3.22\end{array}$ & $\begin{array}{l}0.057 \\
0.0104 \\
0.0041 \\
0.0049 \\
0.000998\end{array}$ & $\begin{array}{r}574 \\
2298 \\
5746 \\
11493 \\
20113\end{array}$ & $\begin{array}{l}32.76 \\
23.91 \\
23.56 \\
56.32 \\
20.07\end{array}$ \\
\hline $\begin{array}{l}8-9 \\
10-11 \\
11-12 \\
12-13 \\
13-14 \\
14-15 \\
15-16\end{array}$ & $\begin{array}{r}10 \\
10 \\
10 \\
1 \\
10 \\
1\end{array}$ & $\begin{array}{l}.001 \\
.001 \\
.001 \\
.001 \\
.00031 \\
.00031\end{array}$ & $\begin{array}{r}66 \\
\quad 66 \\
66 \\
133\end{array}$ & $\begin{array}{l}5.28 \\
1.00 \\
0.34 \\
1.67 \\
0.30 \\
1.57\end{array}$ & $\begin{array}{l}0.0528 \\
0.0100 \\
0.0034 \\
0.00167 \\
0.00093 \\
0.00487\end{array}$ & $\begin{array}{r}575 \\
2299 \\
5747 \\
11493 \\
20113 \\
32181\end{array}$ & $\begin{array}{l}30.34 \\
22.99 \\
19.54 \\
19.19 \\
18.71 \\
15.67\end{array}$ \\
\hline
\end{tabular}


TABLE 10. LINE E. (CONT.)

\begin{tabular}{|c|c|c|c|c|c|c|c|}
\hline \multicolumn{3}{|c|}{$\begin{array}{l}\text { LOt SOCATION } \\
\text { CHIEF OPEUR Spgs } \\
\text { Robert Fargo } \\
\end{array}$} & \multicolumn{2}{|c|}{$\begin{array}{c}\frac{\text { PROJECT }}{\text { LIneE }} \\
\text { ASSISTANTS } \\
\text { Memmi and Strong }\end{array}$} & \multicolumn{3}{|c|}{$15 \frac{\text { DATE }}{\text { JuTy } 1981} \underset{\text { METHOD }}{\text { Dipole-Dipole }\left(N \times 100^{\circ}\right)}$} \\
\hline Sta. & Range & MA & Vol tage & $v_{p}$ & $\mathrm{DV} / \mathrm{I}$ & G.F. & $\mathrm{Pa}_{\mathbf{a}}$ \\
\hline $\begin{array}{r}9-10 \\
11-12 \\
12-13 \\
13-14 \\
14-15 \\
15-16\end{array}$ & $\begin{array}{l}10 \\
10 \\
10 \\
10 \\
1\end{array}$ & $\begin{array}{l}.001 \\
.001 \\
.001 \\
.001 \\
.001\end{array}$ & 100 & $\begin{array}{l}4.47 \\
0.89 \\
3.28 \\
1.73 \\
0.75\end{array}$ & $\begin{array}{l}0.0447 \\
0.0089 \\
0.00328 \\
0.00173 \\
0.00075\end{array}$ & $\begin{array}{r}575 \\
2299 \\
5747 \\
11493 \\
20113\end{array}$ & $\begin{array}{l}25.69 \\
20.46 \\
18.85 \\
19.88 \\
15.09\end{array}$ \\
\hline $\begin{array}{l}10-11 \\
12-13 \\
13-14 \\
14-15 \\
15-16\end{array}$ & $\begin{array}{l}10 \\
10 \\
10 \\
1\end{array}$ & $\begin{array}{l}.001 \\
.001 \\
.001 \\
.001\end{array}$ & $\begin{array}{l}133 \\
133 \\
133 \\
133\end{array}$ & $\begin{array}{l}4.74 \\
0.96 \\
0.44 \\
1.56\end{array}$ & $\begin{array}{l}0.0474 \\
0.0096 \\
0.0044 \\
0.00156\end{array}$ & $\begin{array}{r}575 \\
2299 \\
5747 \\
11493\end{array}$ & $\begin{array}{l}27.24 \\
22.07 \\
25.28 \\
17.93\end{array}$ \\
\hline $\begin{array}{r}11-12 \\
13-14 \\
14-15 \\
15-16\end{array}$ & $\begin{array}{r}100 \\
10 \\
10\end{array}$ & $\begin{array}{l}.001 \\
.001 \\
.001\end{array}$ & 100 & $\begin{array}{l}0.44 \\
1.05 \\
0.35\end{array}$ & $\begin{array}{l}0.044 \\
0.0105 \\
0.0035\end{array}$ & $\begin{array}{r}575 \\
2299 \\
5747\end{array}$ & $\begin{array}{l}25.28 \\
24.14 \\
20.11\end{array}$ \\
\hline $\begin{array}{r}12-13 \\
14-15 \\
15-16\end{array}$ & $\begin{array}{r}100 \\
10\end{array}$ & $\begin{array}{l}.001 \\
.001\end{array}$ & 100 & $\begin{array}{l}0.53 \\
0.86\end{array}$ & $\begin{array}{l}0.053 \\
0.0086\end{array}$ & $\begin{array}{r}575 \\
2299\end{array}$ & $\begin{array}{l}30.46 \\
19.77\end{array}$ \\
\hline $\begin{array}{c}13-14 \\
15-16\end{array}$ & 100 & .001 & 100 & 0.50 & 0.050 & 575 & 28.73 \\
\hline $\begin{aligned} \text { GEND: } & \text { Ra } \\
& M A \\
& \\
& \\
& G \\
& \\
& P a \\
& \\
& D V\end{aligned}$ & $\begin{array}{l}=\mathrm{Ga} \\
=\mathrm{Du} \\
=\mathrm{Ba} \\
=\mathrm{Ge} \\
=\mathrm{Ap} \\
=\mathrm{Ra}\end{array}$ & $\begin{array}{l}\text { TX } \\
\text { e cc } \\
\text { ric } \\
\text { nt } \\
x \text { MA }\end{array}$ & $\begin{array}{l}\text { rent Sw } \\
\text { rol to } 1 \\
\text { ctor } \\
\text { istivits } \\
\text { Vp }\end{array}$ & Meter & & & \\
\hline
\end{tabular}


APPENDIX F. RESISTIVITY CALCULATIONS

TABLE 11. LINE F.

\section{COLORADO GEOLOGICAL SURVEY \\ Geophysical Exploration \\ (Resistivity Survey)}

Hot $\frac{\text { LOCATION }}{\text { SUTphur Spgs }}$

CHIEF OPERATOR

Robert Fargo
PROJECT
Line F
ASSISTANTS Memmi and Strong

\begin{tabular}{|c|c|c|c|c|c|c|c|}
\hline Sta. & Range & MA & Voltage & $v_{\mathbf{p}}$ & DV $/ \mathrm{I}$ & G.F. & $\mathrm{Pa}_{\mathrm{a}}$ \\
\hline $\begin{array}{l}-2 \\
3-4 \\
4-5 \\
5-6 \\
6-7 \\
7-8 \\
8-9\end{array}$ & $\begin{array}{c}1,000 \\
10 \\
10 \\
1 \\
1 \\
1\end{array}$ & $\begin{array}{l}.001 \\
.001 \\
.001 \\
.001 \\
.001 \\
.001\end{array}$ & 100 & $\begin{array}{l}0.511 \\
3.71 \\
1.08 \\
3.44 \\
1.44 \\
0.67\end{array}$ & $\begin{array}{l}1 \\
371 \\
108 \\
0344 \\
0144 \\
0067\end{array}$ & $\begin{array}{r}574 \\
2298 \\
5745 \\
11491 \\
20109 \\
32174\end{array}$ & $\begin{array}{r}293.01 \\
85.26 \\
62.05 \\
39.53 \\
28.96 \\
21.56\end{array}$ \\
\hline $\begin{array}{c}2-3 \\
4-5 \\
5-6 \\
6-7 \\
7-8 \\
8-9 \\
9-10\end{array}$ & $\begin{array}{c}100 \\
10 \\
10 \\
1 \\
1 \\
1\end{array}$ & $\begin{array}{l} \\
.001 \\
.001 \\
.001 \\
.001 \\
.001 \\
.001\end{array}$ & $\begin{array}{l}133 \\
133\end{array}$ & $\begin{array}{l}1.40 \\
2.11 \\
0.54 \\
1.94 \\
0.84 \\
0.41\end{array}$ & $\begin{array}{l}0.140 \\
0.0211 \\
0.0054 \\
0.00194 \\
0.00084 \\
0.00041\end{array}$ & $\begin{array}{r}574 \\
2298 \\
5746 \\
11491 \\
20109 \\
32174\end{array}$ & $\begin{array}{l}80.43 \\
48.49 \\
31.02 \\
22.29 \\
16.89 \\
13.19\end{array}$ \\
\hline $\begin{array}{c}3-4 \\
5-6 \\
6-7 \\
7-8 \\
8-9 \\
9-10 \\
10-11\end{array}$ & $\begin{array}{r}100 \\
10 \\
10 \\
10 \\
1 \\
1\end{array}$ & $\begin{array}{l}.001 \\
.001 \\
.001 \\
.001 \\
.001 \\
.001\end{array}$ & 133 & $\begin{array}{l}2.26 \\
3.82 \\
1.09 \\
0.39 \\
1.82 \\
1.54\end{array}$ & $\begin{array}{l}0.226 \\
0.0382 \\
0.0109 \\
0.0039 \\
0.00182 \\
0.00154\end{array}$ & $\begin{array}{r}574 \\
2298 \\
5746 \\
11491 \\
20119 \\
32174\end{array}$ & $\begin{array}{r}129.93 \\
87.79 \\
62.62 \\
44.81 \\
36.60 \\
49.55\end{array}$ \\
\hline $\begin{array}{c}4-5 \\
6-7 \\
7-8 \\
8-9 \\
9-10 \\
10-11 \\
11-12\end{array}$ & $\begin{array}{r}100 \\
10 \\
10 \\
1 \\
1 \\
10\end{array}$ & $\begin{array}{l}.001 \\
.001 \\
.001 \\
.001 \\
.001 \\
.00031\end{array}$ & $\begin{array}{r}100 \\
1 \quad 200\end{array}$ & $\begin{array}{l}1.20 \\
2.44 \\
0.73 \\
3.10 \\
2.43 \\
0.57\end{array}$ & $\begin{array}{l}0.120 \\
0.0244 \\
0.0073 \\
0.00310 \\
0.00243 \\
0.00171\end{array}$ & $\begin{array}{r}575 \\
2299 \\
5747 \\
11491 \\
20109 \\
32174\end{array}$ & $\begin{array}{l}68.94 \\
56.07 \\
41.94 \\
35.62 \\
48.96 \\
55.02\end{array}$ \\
\hline
\end{tabular}


TABLE 11. LINE F. (CONT.)

\begin{tabular}{|c|c|c|c|c|c|c|c|}
\hline \multicolumn{3}{|c|}{$\begin{array}{l}\text { LOCATION } \\
\text { Hot SUTphur Spgs } \\
\text { CHIEF OPERATOR } \\
\text { Robert Fargo } \\
\end{array}$} & \multicolumn{2}{|c|}{$\begin{array}{c}\frac{\text { PROJECT }}{\text { Line F }} \\
\text { ASSISTANTS } \\
\text { Memmi and Strong }\end{array}$} & \multicolumn{3}{|c|}{ 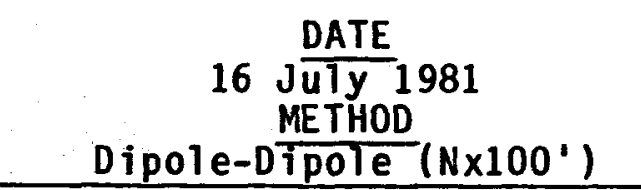 } \\
\hline Sta. & Range & MA & Voltage & $v_{p}$ & $\mathrm{DV} / \mathrm{I}$ & G.F. & $\mathrm{Pa}$ \\
\hline $\begin{array}{c}5-6 \\
7-8 \\
8-9 \\
9-10 \\
10-11 \\
11-12\end{array}$ & $\begin{array}{r}100 \\
10 \\
10 \\
10 \\
10\end{array}$ & $\begin{array}{l}.001 \\
.001 \\
.001 \\
.001 \\
.001\end{array}$ & 66 & $\begin{array}{l}1.57 \\
2.73 \\
0.88 \\
0.60 \\
0.38\end{array}$ & $\begin{array}{l}0.157 \\
0.0273 \\
0.0088 \\
0.0060 \\
0.00385\end{array}$ & $\begin{array}{r}575 \\
2299 \\
5747 \\
11491 \\
20109\end{array}$ & $\begin{array}{l}86.75 \\
62.74 \\
50.56 \\
68.94 \\
76.41\end{array}$ \\
\hline $\begin{array}{l}6-7 \\
8-9 \\
9-10 \\
10-11 \\
11-12\end{array}$ & $\begin{array}{r}100 \\
10 \\
10 \\
10\end{array}$ & $\begin{array}{l}.001 \\
.001 \\
.001 \\
.001\end{array}$ & 100 & $\begin{array}{l}0.88 \\
1.92 \\
1.01 \\
0.55\end{array}$ & $\begin{array}{l}0.088 \\
0.0192 \\
0.0101 \\
0.0055\end{array}$ & $\begin{array}{r}575 \\
2299 \\
5747 \\
11491\end{array}$ & $\begin{array}{l}50.56 \\
44.12 \\
58.03 \\
63.20\end{array}$ \\
\hline $\begin{array}{l}7-8 \\
9-10 \\
10-11 \\
11-12\end{array}$ & $\begin{array}{r}100 \\
10 \\
10\end{array}$ & $\begin{array}{l}.001 \\
.001 \\
.001\end{array}$ & 100 & $\begin{array}{l}0.49 \\
1.71 \\
0.76\end{array}$ & $\begin{array}{l}0.049 \\
0.0171 \\
0.0076\end{array}$ & $\begin{array}{r}575 \\
2299 \\
5747\end{array}$ & $\begin{array}{l}28.15 \\
39.30 \\
43.66\end{array}$ \\
\hline $\begin{array}{l}8-9 \\
10-11 \\
11-12\end{array}$ & $\begin{array}{l}10 \\
10\end{array}$ & $\begin{array}{l}.001 \\
.001\end{array}$ & 100 & $\begin{array}{l}3.80 \\
1.07\end{array}$ & $\begin{array}{l}0.038 \\
0.0107\end{array}$ & $\begin{array}{r}575 \\
2299\end{array}$ & $\begin{array}{l}21.83 \\
24.59\end{array}$ \\
\hline $\begin{array}{l}9-10 \\
11-12\end{array}$ & 10 & .001 & 133 & 3.56 & 0.0356 & 575 & 20.45 \\
\hline
\end{tabular}

LEGEND: Range $=$ Gain

MA = Dummy TX Current Switch

Vp = Balance Control to Null Meter

G.F. = Geometric Factor

$\mathrm{Pa}=$ Apparent $\cdot$ Resistivity

$D V / I=$ Range $\times$ MA $\times V_{p}$ 
Special Pub. 10, HYDROGEOLOGICAL AND GEOTHERMAL INVESTIGATIONS OF PAGOSA SPRINGS, COLORADO, bY M.A. GallowaY WITH A SECTION ON MINERALOGICAL AND PETROGRAPHIC INVESTIGATIONS OF SAMPLES FROM GEOTHERMAL WELLS $0-1$ AND P-1, PAGOSA SPRINGS, COLORADO, by W.W. Atkinson, $1980,95 \mathrm{p} . \$ 10.00$

Special PUb. 16, GEOTHERMAL RESOURCE ASSESSMENT OF WAUNITA HOT SPRINGS, COLORADO, ed. by T. G. Zacharakis, 1981,69 p., Free over the counter.

Special Pub. 18, GROUNDWATER HEAT PUMPS IN COLORADO, AN EFFICIENT AND COST EFFECTIVE WAY TO HEAT AND COOL YOUR HOME, by K.L. Garing and F.R. Connor, 1981, 32 p., Free over the counter.

Map Series 14, GEOTHERMAL RESOURCES OF COLORADO, by R.H. Pearl, Scale 1:500,000, Free over the counter.

Map Series 18, REVISED HEAT FLON MAP OF COLORADO, by T.G. Zacharakis, Scale 1:1,000,000, Free over the counter.

Map Series 20, GEOTHERMAL GRADIENT MAP OF COLORADO, by F.N. Repplier and R.L. Fargo, 1981, Scale 1: 1,000,000, Free over the counter.

Info. Series 4, MAP SHOWING THERMAL SPRINGS, WELLS, AND HEAT FLOW CONTOURS IN COLORADO, by J.K. Barrett, R.H. Pearl and A.J. Pennington, 1976, Scale 1:1,000,000, out of print.

Info. Series 6, HYDROGEOLOGICAL DATA OF THERMAL SPRINGS AND WELLS IN COLORADO, by J.K. Barrett and R.H. Pearl, 1976, 124 p. $\$ 4.00$

Info. SerIES 9, GEOTHERMAL ENERGY DEVELOPMENT IN COLORADO, PROCESSES, PROMISES ANO PROBLEMS, bY B.A. COE, 1978, 51 P., \$3.00

Info. Series 15, REGULATION OF GEOTHERMAL ENERGY DEVELOPMENT IN COLORADO, bY B.A. Coe and N.A. Forman, 1980, Free over the counter.

Open-file Report 80-10, GEOTHERMAL POTENTIAL IN CHAFFEE COUNTY, COLORADO, by. F.C. Healy, 47 p., Free over the counter.

Open-File Report 80-11, COMMUNITY DEVELOPMENT OF GEOTHERMAL ENERGY IN PAGOSA SPRINGS, COLORADO; by B.A. COE, 1980 , Free over the counter.

Open-file Report 80-12, TEMPERATURE-DEPTH PROFILES IN THE SAN LUIS VALLEY AND CANON CITY AREA, COLORADO, DY C.D. Ringrose. Free over the counter.

Open-File Report 80-13, GEOTHERMAL ENEREY POTENTIAL IN THE SAN LUIS VALLEY, COLORADO, by B.A. Coe, 1980, 44 P.; Free over the counter.

OpEn-F1le Report 81-2, GEOTHERMAL ENERGY OPPORTUNITIES AT FOUR COLORADO TOWNS, by B.A. Coe and Judy Zimmerman, 1981, Free over the counter.

Open-File Report 81-3, APPENDICES OF AN APPRAISAL FOR THE USE OF GEOTHERMAL ENERGY IN STATE-OWNED BUILOINGS IN COLORADO: SECTION A, AI amOSa; SECTION B, BUENA VISTA; SECTION C, BURLINGTON: SECTION'D, DURANGO; SECTION E, GLENWOOD SPRINGS; SECTION F, STEAMBOAT SPRINGS, $1981, \$ 1.50$ each or $\$ 8.00$ for the set.

Pamphlet, GEOTHERMAL ENERGY-COLORADO'S UNTAPPED RESOURCE, Free over the counter.

In addition to the above charges there is an additional charge for all mall orders. Contact the Colorado Geol. Survey for exact amount. To order publications specify series and number, title and quantity desired. Prepayment is required. Make Checks payable to: Colorado Geological Survey, Rm. 715, 1313 Sherman St., Denver, Colorado 80203 (303/866-2611). 
Following is a list of publications relating to the geothermal energy resources of Colorado published by the Colorado Geological Survey.

BU11. 11, MINERAL WATERS OF COLURADO, by R.D. George and others, 1920, $474 \mathrm{p}$., out of print.

BU11. 35, SUMMARY OF GEOLOGY OF COLORADO RELATED TO GEOTHERMAL ENERGY POTENTIAL, PROCEEDINGS' OF A SYMPOSIUM ON GEOTHERMAL ENERGY AND COLORADO, ed. by R.H. Pearl, 1974, \$3.00

BU11. 39, AN APPRAISAL OF COLORADO'S GEOTHERMAL RESOURCES, by J.K. Barrett and R.H. Pearl, 1978, 224 p., $\$ 7.00$

BU11. 44, BIBLIOGRAPHY OF GEOTHERMAL REPORTS IN COLORADO, bY R.H. Pearl, T.G. Zacharakis, F.N. Repplier and K.P. McCarthy, 1981, 24 p., \$2.00.

Resource Ser. 6, COLORADO'S HYDROTHERMAL RESOURCE BASE--AN ASSESSMENT, by R.H. Pearl, 1979, 144 p., $\$ 2.00$.

Resource Ser. 14, AN APPRAISAL FOR THE USE OF GEOTHERMAL ENERGY IN STATE OWNED BUILOINGS IN COLORADO, bY R.T. Meyer, B.A. COE and J.D. Dick, $1981,63 \mathrm{p.}, \$ 5.00$.

Resource Ser. 15, GEOTHERMAL RESOURCE ASSESSMENT OF OURAY, COLORADO, by T.G. Zacharakis, C.D. Ringrose and R.H. Pear1, 1981, 70 p., Free over the counter.

Resource Ser. 16, GEOTHERMAL RESOURCE ASSESSMENT OF IDAHO SPRINGS, COLORADO. by F.N. Repplier, T.G. Zacharakis, and C.D. Ringrose, 1982, Free over the counter.

Resource SEr. 17, GEOTHERMAL RESOURCE ASSESSMENT OF THE ANIMAS VALLEY, COLORADO, by K.P. MCCarthy, T.G. Zacharakis and C.D. Ringrose, 1982 , Free over the counter.

Resource Ser. 18, GEOTHERMAL RESOURCE ASSESSMENT OF HARTSEL, COLORADO, by K.P. MCCarthy, T.G. Zacharakis, and R.H. Pearl, 1982, Free over the counter.

Resource Ser. 19, GEOTHERMAL RESOURCE ASSESSMENT OF WESTERN SAN LUIS VALLEY, by T.G. Zahcarakis, R.H. Pearl and C.D. Ringrose, 1982, Free over the counter.

Resource Ser. 20, GEOTHERMAL RESOURCE ASSESSMENT OF CANON CITY AREA, COLORADO, BY T.G. Zacharakis and R.H. Pearl, 1982, Free over the counter.

Resource Ser. 22, GEOTHERMAL RESOURCE ASSESSMENT OF STEAMBOAT SPRINGS AREA, COLORADO, by R.H. Pearl, T.G. Zacharakis and C.D. Ringrose, 1982, Free over the counter.

Resource Ser. 23, GEOTHERMAL RESOURCE ASSESSMENT OF HOT SULPHUR SPRINGS, COLORADO, by R.H. Pearl, T.G. Zacharkis and C.D. Ringrose 1982, Free over the counter.

Resource SEr. 24, GEOTHERMAL RESOURCE ASSESSMENT OF RANGER HOT SPRINGS, COLORADO, by T.G. Zacharakis and R.H. Pear1, 1982, Free over the counter.

Special Pub. 2, GeOTHERMAL RESOURCES OF COLORADO, by R.H. Pear?, 1972, 54 p. $\$ 2.00$.

(CONTINUED ON INSIDE OF BACK COVER) 